Florida International University FIU Digital Commons

$11-23-2004$

\title{
The phonological analysis of bilingual Creole/ English children living in South Florida
}

Carolyn F. Beaubrun

Florida International University

DOI: $10.25148 /$ etd.FI14050464

Follow this and additional works at: https://digitalcommons.fiu.edu/etd

Part of the Pathology Commons, and the Speech Pathology and Audiology Commons

\section{Recommended Citation}

Beaubrun, Carolyn F., "The phonological analysis of bilingual Creole/English children living in South Florida" (2004). FIU Electronic Theses and Dissertations. 1470.

https://digitalcommons.fiu.edu/etd/1470 


\section{FLORIDA INTERNATIONAL UNIVERSITY}

Miami, Florida

THE PHONOLOGICAL ANALYSIS OF BILINGUAL

CREOLE/ ENGLISH CHILDREN LIVING

IN SOUTH FLORIDA

A thesis submitted in partial fulfillment of the requirements for the degree of

MASTER OF SCIENCE

in

SPEECH LANGUAGE PATHOLOGY

by

Carolyn F. Beaubrun 
To: Dean Ronald M. Berkman

College of Health and Urban Affairs

This thesis, written by Carolyn F. Beaubrun, and entitled The Phonological Analysis of Bilingual Creole/ English Children Living in South Florida, having been approved in respect to style and intellectual content, is referred to you for judgment.

We have read this thesis and recommend that it be approved.

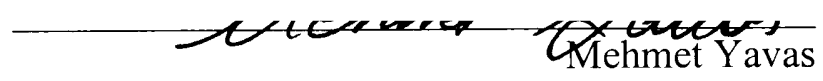

Alfredo Ardila

Date of Defense: November 23, 2004

The thesis of Carolyn F. Beaubrun is approved.

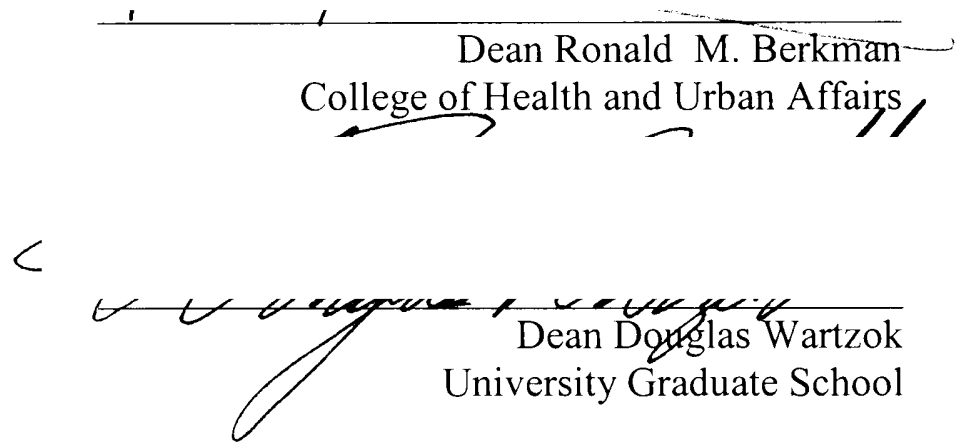

Florida International University, 2004 


\section{DEDICATION}

I dedicate this thesis to my mother. Without her guidance, her understanding and support, and most of all her love, the completion of this work would not have been possible. And to Erik, my biggest cheerleader. Thank you for believing in me! 


\section{ACKNOWLEDGMENTS}

I wish to thank the members of my committee for their support, patience, and guidance. Dr. Yavas was particularly helpful in sparking an interest in second language acquisition. My passion for phonology began in your class. Dr. Ardila's thoughtful and constructive guidance has been most appreciated. Finally, I would like to thank Dr. McNeilly, my major professor. Thank you for all of the motivation you've provided me throughout this learning experience. You are a true inspiration!

I also wish to thank the faculty and staff in the Communication Sciences and Disorders Department. Thank you to Dr. Anderson, your speech on 'confidence' has kept me going. Also, many thanks to my colleagues. Dearta Smith, we can truly say that we know the meaning of 'team work'. Yamillee Wolff, thank you for always listening. You have all played an important part in the completion of my degree. I have found my years of study at this institution to be stimulating and challenging, providing me with the tools for a successful career. 


\section{ABSTRACT OF THE THESIS \\ THE PHONOLOGICAL ANALYSIS OF BILINGUAL CREOLE/ ENGLISH \\ CHILDREN LIVING IN SOUTH FLORIDA}

by

Carolyn F. Beaubrun

Florida International University, 2004

Miami, Florida

Professor Lemmietta McNeilly, Major Professor

The purpose of this study was to gather normative data regarding the phonological system of bilingual Creole-English children ages three and five and to compare performance to norms for English speaking children. The forty participants lived in Miami and represented low socio-economic groups.

Participants were assessed using the Goldman-Fristoe Test of Articulation-2 and a Haitian Creole Picture Naming Assessment. The results indicated that the percentage of correct phonemes in Creole $(\underline{M}=91.6)$ were not significantly different when compared to the correct production of the same phonemes in English $(\underline{\mathrm{M}}=92.8)$. Further analysis revealed that the accuracy of all phonemes was higher for the five-year $(\underline{M}=90.8)$ as compared to the three-year-olds $(\underline{M}=85)$ in Creole. In English, the five-year-olds performed better than the three-year-olds participants.

These findings revealed patterns of phonological development in bilingual Creole/English Children similar to patterns reported in other bilingual children. This information is essential in the evaluation and treatment of this population. 


\section{TABLE OF CONTENTS}

CHAPTER

PAGE

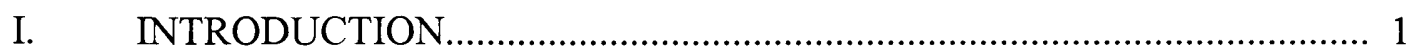

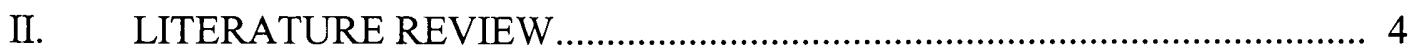

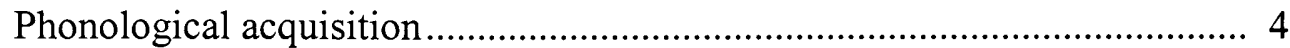

- Monolingual phonological acquisition ............................. 4

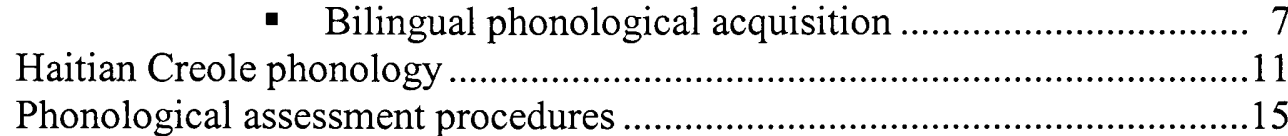

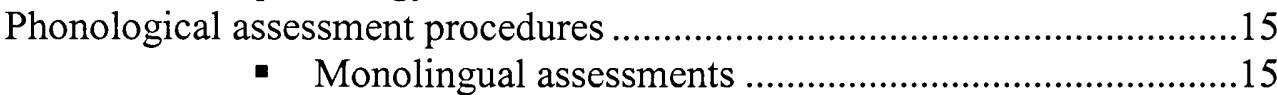

- Bilingual assessments ......................................................16

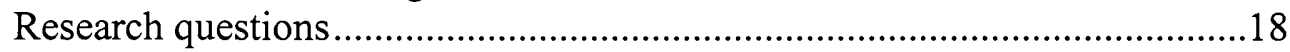

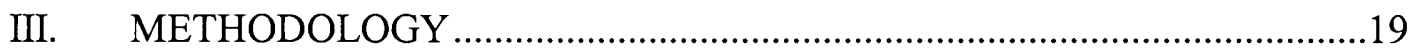

Participants and settings............................................................................19

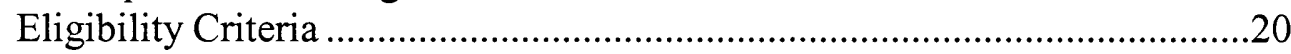

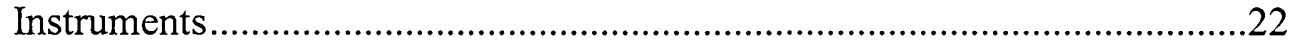

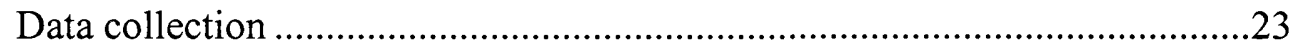

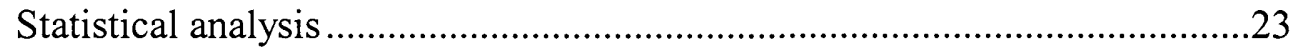

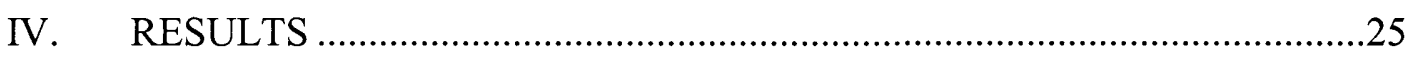

Phonological repertoire of coexisting phonemes ..........................................25

Age of acquisition of Haitian Creole consonants........................................27

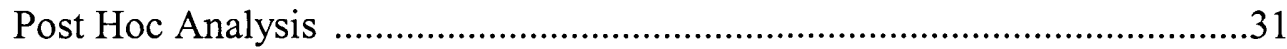

- Performance Based Exposure ................................... 31

- Percentage of all correct phonemes in English/Creole ....32

- Analysis of Errors ..............................................................33

- Gender Based Performance.................................................35-

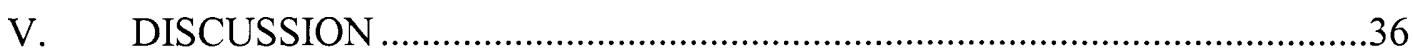

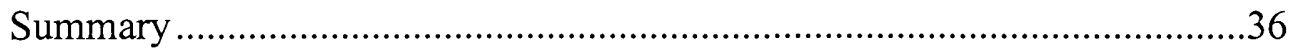

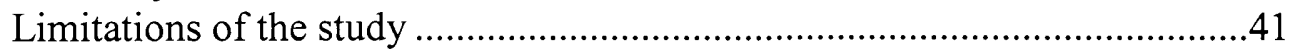

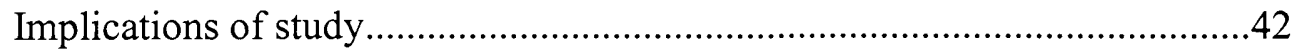

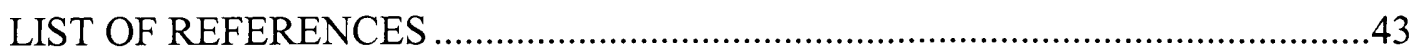

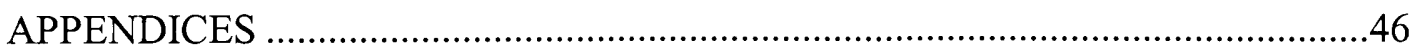




\section{LIST OF TABLES}

TABLE

PAGE

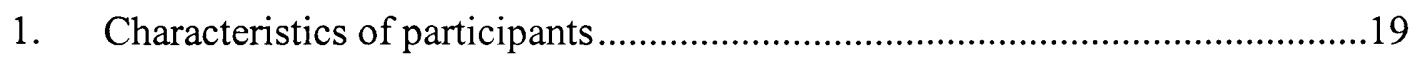

2. Percentage of English use compared to Haitian Creole ....................................22

3. Percent of correct production of coexisting phonemes ..................................27

4. Group differences in the phonemic production by age ...................................29

5. Age of mastery for Haitian Creole Consonants ................................................30

6. Mean percentage of correct production of all phonemes .................................33

7. Percentage of errors of all Creole phonemes ......................................................

8. Percentage of errors in all English phonemes .................................................34

9. Differences in the percentage of correct production of phonemes by gender...35 
Chapter 1

\section{INTRODUCTION}

The assessment of bilingual children has become a particular area of interest in the field of speech language pathology. Many studies have been conducted on bilingual phonological acquisition (Bruck and Genesee, 1995; Genesee, Nicoladis and Paradis, 1995; Haznedar, 2001; Goldstein and Iglesias, 1998; Yavas and Goldstein, 2004). One language where research is lacking is Haitian Creole. According to researchers, children from culturally different backgrounds where English is the second language learned, constitute an increasing proportion of school-aged children. One of the largest ethnic groups receiving speech therapy in Miami in early intervention programs is Haitian American. The language barriers often experienced by these young Haitian American children frequently impair their performances on standardized speech and language assessment tools. Simply translating an existing standardized assessment tool into the child's native language does not necessarily result in a test that will permit a fair assessment for that particular group. As a consequence, they are at risk for being improperly placed into programs offering remedial education. Despite the need, little research has been conducted in the phonological development of bilingual Haitian American children. Given the critical role of bilingualism in the field of communication disorders, it is important that speech-language pathologists become knowledgeable about the cultural norms of their clients (Goldstein and Iglesias 1998).

Many Haitians living across the world are French-Creole bilingual. Because bilingual French-Creole speakers usually receive formal education and are literate, the group that is at the greatest disadvantage is the monolingual group of Haitian Creole 
speakers. According to census information obtained by the University of California Los Angeles (2000), Haitian Creole is a language spoken by more than 6 million people. This number is projected to increase to 10 million by the year 2010 .

There is a great need for research in the area of phonological acquisition in speakers of Haitian Creole. It is imperative that assessment tools for articulation and phonology become available in order to appropriately assess those children that are not part of the normative data collected for Standard English assessments. Goldstein and Iglesias (1998) agree that although tools should be designed to specifically assess phonological patterns in a child's native language, this is often difficult due to the lack of normative data in that particular language.

\section{Purpose of the study}

The purpose of this study is to gather normative data of the phonological system of normally developing bilingual Creole-English Haitian American children living in south Florida and compare it to already established normative data for monolingual English speaking children. Because there is an increasing amount of awareness concerning cultural sensitivity in assessing and treating bilingual children, it is important to determine how bilingual Haitian American children acquire phonology. Miami is a diverse ethnic community in which speech-language pathologists find themselves working with children and families from various language backgrounds on a daily basis. Therefore, becoming aware of Haitian American children's typical phonological repertoire is important if speech-language pathologists are going to provide effective assessment and treatment of that particular ethnic group. 


\section{Chapter 2}

\section{REVIEW OF THE LITERATURE}

Speech therapy has been identified as one of the most commonly requested services for children enrolled in early intervention programs. In order to understand the need for therapy in early intervention, one must understand the various aspects of assessment and intervention. A child's phonological repertoire is a key element in obtaining a valid and reliable assessment. In the past two decades, bilingualism has become a vast area of interest in the realm of communication sciences and disorders. Many children living in South Florida acquire two languages simultaneously. Though studies in the past have analyzed monolinguals, it is becoming customary to analyze the speech of bilingual/bicultural children. Culture is believed to be an intricate part of therapy services. Thus, many agree that in order to provide optimal therapeutic services, a clinician must understand both families and culture.

In a recent study conducted across five states regarding speech- language pathologists' beliefs on language assessment of bilingual and bicultural individuals, it was estimated that as much as $95 \%$ of speech-language pathologists service bilingual and/or bicultural children; of the $95 \%$ of the participants less than half of them reported being inefficient when working with bilingual and or bicultural children (Kritikos, 2003). These findings demonstrate the need for further training for all speech pathologists working with bilingual/bicultural children. Furthermore, the American Speech-Language and Hearing Association's (ASHA) position statement warns clinicians of the difference between speech disorders vs. speech differences (ASHA, 1983). Thus, the issue of 
bilingualism and assessment must be further analyzed in order to provide more effective approaches to clinical evaluations and interventions.

\section{Phonological Acquisition}

\section{Monolingual Phonological Acquisition}

Phonology is the branch of the linguistic sciences, which is concerned with the study of spoken language (Grunwell, 1987). The phonological system contains several components that combine to create spoken language. These systems include the phonotactic repertoire, the phonetic repertoire, the phonemic repertoire, phonological patterns such as processes, rules, or constraints, and suprasegmental patterns or prosody. For the purpose of this study, the three components that will be analyzed will consist of the phonotactic repertoire, the phonetic repertoire, and the phonemic repertoire. It is with the merging of these various components that children begin to acquire language.

According to linguists, the phonotactic repertoire describes what syllable and word shapes are available for use. The phonetic repertoire deals with what sounds (and features) are available to form the syllables and word shapes. Moreover, the phonemic repertoire looks at each sound's role and how the sounds contrast to yield the final pronunciation (Velleman, 1998). Many studies have been conducted on the acquisition of language based on those repertoires with monolingual children (Templin, 1957; Prather, Hedrick, \& Kern, 1975; Elbert and McReynolds, 1979; Grunwell, 1985; Kenney \& Prather, 1986; Stoel-Gammon, 1991; Anderson and Smith, 1987).

Linguists concur that the acquisition of language arises from the various stages of phonological development. Those stages are described as the prelinguistic stage, the fifty-word-stage, and the systematic stage. According to Yavas (1998), at the systematic 
stage following the fifty-word-stage, the child develops a phonological system in which most of the phonemes are established. In many languages, the acquisition of phonemes tend to follow an order where stops, nasals, and glides are mastered early which in turn are followed by the mastery of liquids, fricatives, and affricates (Yavas, 1998).

Furthermore, Stoel-Gammon and Dunn (1985) conducted a study on the age of mastery of consonantal phonemes. The authors reported that by age three, children had mastered the following phonemes: $/ \mathrm{p} /, / \mathrm{m} /, / \mathrm{n} /, / \mathrm{w} /$, and $/ \mathrm{h} /$; whereas mastery production for $/ \mathrm{b} /, / \mathrm{d} /$, $/ \mathrm{k} /, / \mathrm{g} /, / \mathrm{f} /$, and $/ \mathrm{j} /$ occurred by age four. For the purpose of their study, mastery was defined as $75 \%$ of the children able to correctly produce the phonemes. Contrastively, Yavas (1998) expressed divergent views concerning their study in terms of the age of mastery for the /t/ phoneme, which usually is mastered earlier than reported by StoelGammon and Dunn. Moreover, in a study conducted with monolingual children by Porter and Hodson (2001), results showed that all major phoneme classes were acquired by age four except liquids. Additionally, similar studies on first language acquisition report that by age two a child's consonantal repertoire is well on its way toward the full repertoire of the adult system (Stoel-Gammon, 1991). Thus, many agree that a child's level of intelligibility has a direct correlation with the number of phonemes they produce.

Numerous studies have looked at the production of phonemes in word positions. As previously stated, the phonemic repertoire looks at each sound's role and how the sounds contrast to yield the final pronunciation (Velleman, 1998). Grunwell (1987) and Yavas (1998) agree that in analyzing phone distribution, four positions in word structure should be examined. Grunwell defines them as onsets and termination. There are two positions that should be analyzed within the onset category: the syllable initial word 
initial position (SIWI), and the syllable initial within word (SIWW). The termination category analyzes the distribution of phones in syllable final within word (SFWW) and in syllable final word final (SFWF). In the case of Haitian Creole, there are limited amounts of words that contain the SFWW distribution. Grunwell agrees that in most clinical samples the SFWW position usually has a rather restricted range of possible targets. Therefore, for the purpose of this study three types of distributions will be analyzed: SIWI, SIWW, and SFWF.

The phonology of every language is believed to have two important factors responsible for shaping it. According to Velleman (1998), the terms ease of production and ease of perception are partly liable for the sounds and sound patterns present in languages. The author conjures that ease of production refers to the "articulatory simplicity" (p.10) while ease of perception refers to the "idea that a language must choose sounds and sound patterns that are distinct that the listener can distinguish them, even in running speech" (p.10). In addition, Yavas (1998) and Major (2001) discuss the issue of naturalness or markedness for the early acquisition of certain phonemes. The authors concur that the "markedness universals deal with occurrence relationship" (p. 42). When a sound is marked it simply means that it is unnatural. According to Major (2001), in the languages of the world, the voiceless stop /p/ is more common than the glottal stop / $/$. If certain phonemes appear more often in a language then based on the theory of markedness, the phonemes that appear more frequently will be acquired earlier than those that appear less frequently. Thus, the statistical frequency is considered to be a direct correlation to markedness. The markedness theory also applies to syllable shape 
in terms of hierarchy. Therefore, if a language has a CVC syllable shape then it implies that CV syllable shapes also exist (Major, 2001). However, the author cautions that the inverse isn't necessarily true.

\section{Bilingual Phonological Acquisition}

Many studies on bilingual phonological acquisition have been conducted with bilingual children (Bruck and Genesee, 1995; Genesee, Nicoladis and Paradis, 1995; Goldstein and Washington, 2001; Haznedar, 2001; Goldstein and Iglesias, 1998; Yavas and Goldstein, 2004). However, one of the most debated issues is whether a bilingual child possesses separate phonological systems or are the systems shared. Currently, there are no clear definitions for the term "bilingualism." Many authors and researchers agree that there are too many degrees of bilingualism to come up with a single definition for the term (Romaine, 1995). However, many agree that there are two main types of bilingualism: simultaneous and successive.

Individuals can acquire two or more languages at any point in their lives. When a person whose first language is English learns another language in school it is commonly

described as successive bilingualism. However, when a person acquires two languages at the same time, the term simultaneous bilingualism is used. Thus, a child who acquires both English and Haitian Creole in the home would be described by using the term simultaneous bilingualism. According to Arnberg (1987), the age of three is considered the cut off point from distinguishing from simultaneous and successive. For the purpose of this study, data collection and analysis will focus on three and five year old children. In the south Florida region, most pre-school bilingual Creole/ English Haitian American 
children usually fall into the simultaneous category due to the fact that two languages are usually acquired at the same time in the home.

There are no known studies that have been conducted on the acquisition of Haitian Creole; therefore, for the purpose of this study, dual language acquisition studies will look at the combination of other languages rather than the acquisition of Haitian Creole and English. Many researchers acknowledge the work of Werner Leopold on bilingual studies. Arnberg (1987) presented the well-known study by Werner Leopold, which demonstrates the patterns in dual language acquisition. As Arnberg (1987) states, in his studies, Leopold presented the case of his daughter Hildegard who was learning German and English at the same time. According to Leopold's findings, the pattern of her language development was similar to that of monolingual children. Major (2001) supports Leopold's finding with his claim of the Ontogeny Phylogeny Model (OPM) of language acquisition, a revised version of his 1987 Ontogeny Model.

According to Major (2001), "the OPM deals with the development of an individual's interlanguage (IL)" (p. 81). Although Major has defined interlanguage as "the language of a nonnative speaker" (p.1), he found that there were five stages in a child's bilingual acquisition. In stage1, there's $100 \%$ of what he refers to as Universal (U) or simply universals of all languages, their commonality. In stage 2, Language A and Language B share the same system. However, it is during the third stage that the two languages start to become differentiated while some aspects are still interconnected. At stage four, Language A and Language B become more separated and share less commonalities. Major claims that at stage five, the acquisition is complete and the two languages have separate equal systems. However, the author advises that such a clear and 
distinct acquisition pattern is nearly impossible since no individual is ever equally competent in both languages. He further postulates that "realistically, a child learns something in one language at a time; it is physically impossible to learn simultaneously the same thing in the other language" (p.128). Thus, supporting the notion that a bilingual child has two systems but is more competent in one depending on the situation or context. Similar to Major, some researchers believe that bilingual children are able to differentiate between their two languages (Ingram 1981; Genesee, 1989). However, other researchers like Volterra and Taeshner (1978) and Yavas (1995) agree that the phonological system of a bilingual child is in fact an undifferentiated system. Yavas further explains that the discrepancies may be due to the developmental stage at which data was obtained and analyzed from the child participants. He further suggests that the phonological system of a child is undifferentiated until the age of two.

Another aspect of second language acquisition that has gained much attention is code mixing. Arnberg (1987) defines the term code switching, interchangeably used with code mixing, as the "conscious and/or purposeful switching of the two languages" (p.27). He explains that one of the major reasons for a bilingual individual to code switch is the lack of vocabulary item in one of the languages. One of the other reasons may be the level of difficulty in terms of phonological production. A word may be easier to produce in one language than the other. Children acquiring two languages simultaneously often code switch during formal assessments. For example, when shown a picture of a "thumb" from the Goldman Fristoe Test of Articulation, a bilingual Haitian child may refer to the item with the Haitian Creole equivalent word "/pus/" due to the lack of the interdentals in their phonological repertoire. This is supported with the theory of 
markedness, which also deals with first language acquisition. According to Major (2001), markedness phenomena will have a slower chronological development than unmarked phenomena. Thus, the more marked phoneme $/ \theta /$ will be harder to produce than the less mark phoneme $/ \mathrm{p} /$.

The idea of code mixing in language differentiation has further been analyzed in various studies. Genesee, Nicoladis, and Paradis (1995) examined language differentiation in five bilingual children. The results of the study illustrated that bilingual children between the one-word stage and the two-word stage were able to differentiate their languages even in unfamiliar linguistic situations. In addition, the rate of code mixing in bilingual children was found to have a direct correlation with their language dominance; "the children tended to mix more when using their non-dominant language then when using their dominant language" (p.628). Thus, proving that bilingual children are not confused or disordered when they start to code switch from one language to the other.

Just as in monolingual phonological acquisition, bilingual phonological acquisition also follows a sequential pattern. According to Jakobson's 1941 theory based on a universal hierarchy, monolingual language acquisition is predicted to be "a) the order of acquisition of minimal consonant and vowel inventories (e.g., $\mathrm{p}>\mathrm{t}>\mathrm{m}>\mathrm{n}$ ); b) stops are acquired before nasals, with fricatives next and liquids late; c) voiceless consonants are acquired before voiced; d) front consonants are acquired before back; e) in the early stages fricatives will be replaced by stops and back consonants by front consonants (Macken and Ferguson, 1987 (p.5)).

A study conducted by Anderson and Smith (1987) examined the phonological development of six two-year-old monolingual Puerto Rican Spanish-speaking children revealed that the phonological development of these children followed the universal 
patterns but language specific factors such as the early acquisition of palatal sounds were also apparent. Most researchers agree that the pattern of phonological acquisition of bilingual children is similar to those of monolingual children. Goldstein and Washington (2001) examined the phonological patterns in twelve typically developing 4-year-old Spanish-English bilingual children and found that there were no significant differences between the two languages in percentage of correctly produced consonants. Thus, it appears that patterns of monolingual phonological development and bilingual phonological development show no significant differences upon analysis.

\section{Haitian Creole Phonology}

Many Haitians living in the United Sates continue to speak their native language and they pass this aspect of their culture onto their children. Although it is generally considered a Romance language, Haitian Creole is not considered a dialect of French. Hall (1971) argues that Haitian Creole is an independent language with most of its origin stemming from French with considerable phonological, morphological and syntactical influences from West African languages. Hall (1971) agrees, “Caribbean French Creole, which shares with French only its vocabulary and, to some extent, its sound system but which is so different from it grammatically that these two kinds of speech must be considered to be two separate languages...”(p. 136). Researchers agree that Haitian Creole can be classified into three main dialects: the dialect of the North, the Dialect of the South and the dialect of the west which include the capital area: Port-au-Prince (Ferere, 1979). The Haitian community in South Florida is relatively linguistically diverse; however, the main dialect spoken is that of the capital, Port-au-Prince. 
The community is divided among those characterized by socioeconomic status (SES) and permanent residence or citizenship in the United States. The group, which composes a significant delay in acquiring English as their second language generally, falls within the low SES category with no established citizenship in the United States. Limited amounts of data are currently available about how Haitian Creole phonology is acquired.

The consonant inventory of Haitian Creole overlaps that of English. It includes few additional consonants and excludes some others (see appendix 1 for table). Most researchers have agreed that the consonants absent from Haitian Creole include the interdentals $/ \theta /$ and $/ \partial /$ and the glottal $/ \mathrm{h} /$; however the issue of the liquid alveolar $/ \mathrm{r} /$ remains a debate among many. Some researchers like Vernet (1980) have presented that segment as a velar approximant. However, according to Valdman (1978) and Cadely (1988), the Haitian Creole / $\mathrm{r} /$ should be phonetically represented as a velar fricative $/ \mathrm{\gamma} /$. For the purpose of this study, the /u/ phonetic symbol will be used to represent the approximant velar sound which has less friction than the velar fricative $/ \mathrm{\gamma} /$ which in turn has less friction than the French $/ \mathrm{r} /$ that has a phonetic representation of $/ \mathrm{b} /$. Professionals like Ferere (1979) argue that the phonology of Haitian Creole contains two phonemes not present in the English phonological system; a voiceless / $\ddot{\mathrm{w}} /$ and a nasalized $/ \mathfrak{j} /$. In contrast, Cadely (2004) suggests that the inventory of Haitian Creole consonants contains the semi-vowel / / / as opposed to Ferere's suggestion of the voiceless semivowel $/ \ddot{w} /$. Moreover, many researchers disregard the inclusion of the Ferere's nasalized semi-vowel $/ \tilde{j} /$. Instead, those that phoneme is attributed to assimilation. 
Because of the lack of research in the area of Haitian Creole phonology, the few researchers involved have had different opinions on the classification of phonemes. Hall (1971) argues that the phonological inventory of Haitian Creole lacks sounds like the palatal alveolar affricates $/ \mathrm{t} \int /$ and $/ \mathrm{d} 3 /$. He further argues that the glottal $/ \mathrm{h} /$ is present in the dialects spoken in the southern parts of the country. In addition, Hall (1971) and Ferere (1979) have disagreed on the vowel system. According to Hall (1971), Haitian Creole has seven vowels, which are all voiced and relatively short. However, in his study, Ferere (1971) argues that the vowel repertoire of Haitian Creole contains 10 vowels that could either be oral or nasal. In contrast, Vernet (1980), Dejean (1977) Cadely (2004) agree the vowel system in Haitian Creole is composed of seven oral vowels and five nasal vowels that are in contrastive distribution. Thus, by substituting an oral vowel for a nasal vowel will change the meaning of the word. For the purpose of this study, the Haitian Creole consonant system will concentrate on its 20 consonants as described in the works of Vernet (1980) and Cadely (2004) (See appendix for table). The distribution of sounds is an important aspect of phonology that tends to be overlooked by many speech pathologists. Yavas (1998) suggests that a phonemic analysis is an "indispensable tool for linguists, language teachers and speech pathologists." The sound distribution in Haitian Creole is often considered an intricate part of the language. According to Cadely (2004), the phonemes $/ \mathrm{b} /, / \mathrm{d} /$, and $/ \mathrm{\gamma} /$ are the only phonemes in the inventory that present with "interruption" in terms of distribution. The phonemes $/ \mathrm{b} /$ and $/ \mathrm{d} /$ do not occur in final position following a nasal vowel. In addition, the velar fricative $/ \mathrm{y} /$ does not appear in final position as well as in the 
environment of rounded vowels such as /o/, / / and /u/. Furthermore, Cadely (1988) postulates that the phoneme $/ \mathrm{\gamma} /$ often appears in free variation with the bilabial glide $/ \mathrm{w} /$ usually with the northern dialect of Haitian Creole. As in with most world languages, the phoneme $/ \mathfrak{y} /$ does not occur in initial position in Haitian Creole. All other phonemes in the Haitian consonantal inventory are capable of appearing in initial, medial and final positions.

Another aspect to consider when looking at phonological patterns in languages is the phonotactic repertoire. The phonotactic repertoire is described as the syllable and word shapes available in a particular language (Velleman, 1998). According to Cadely (2004), in Haitian Creole, the syllabic inventory consists of 8 common syllable shapes (see appendix 2 for table). Just as in English, the Haitian Creole syllabic inventory contains various forms of clusters ranging from initial consonant clusters to final consonant clusters. The following are possible word initial clusters in Haitian Creole: dr, br, pr, tr, kr, gr, fr, fl, pl, bl, dl, kl, gl, bw, pw, dw, tw, nw, zw, $\int_{w}$, and pj. For the purpose of this study, data will be collected on these clusters and will be analyze only in word initial for they do not occur frequently in medial and in final positions.

The phonology of a language plays an important role in the diagnosis and intervention of communication disorders. It is important to understand the various aspects of the language in order to properly identify children with a normally developing phonological system from those with a disordered system. Norms must be established in order to compare those Haitian Creole bilingual children to normally developing children. If professionals hope to implement culturally sensitive assessment and treatment procedures, efforts must be made to gain a basic understanding of that language. 


\section{Phonological Assessment Procedures}

Monolingual Assessments

One of the key components in evaluating a child with phonological delay or disorder is to gather information on how the speech sounds are being produced. A phonological delay is defined as errors that persist in older children but are often present in younger normally developing; whereas a phonological disorder is defined as sound errors that differ from normally developing children (Bankson and Bernthal, 1998). However, the authors warn that differentiation should not be made between the two terms since "most children with multiple misarticulations will have errors that fall into both categories" (p. 234). In addition, the authors concur that the primary purpose of a phonological assessment is to determine whether or not intervention should be warranted and if so, determine the goals of treatment. In addition, Peña-Brooks and Hegde (2000) make the distinction between testing for phonological delays or disorders and articulation disorders. According to the authors, articulation errors are "sound production resulting in nonstandard speech sounds" (p.95); whereas, "phonological errors result in neutralization of sound contrast" (p.96) which are often referred to as sound class errors.

For decades speech-language pathologists have used formal assessments tools to diagnose articulation errors. Several formal assessment instruments are widely used. However, many speech-language pathologists have chosen to use the Goldman-Fristoe Test of Articulation 2 (GFTA-2) as a tool to assess the production of consonants. The test is arranged in three sections. The first section, Sounds-in-Words consist of 53 target words to elicit the articulation of 61 consonants. The consonants are assessed in initial, medial, and final word positions. Twenty-three of the twenty-five sounds of the Standard 
English consonants are in assessed in the GFTA-2. The sounds $/ \mathrm{hw} /$ and $/ 3 /$ are not assessed due to their lack of occurrence in Standard English. In addition, sixteen consonant clusters are elicited in the initial word position. The second section of the GFTA-2 is designed to assess Sound in Sentences (Goldman and Fristoe, 2000). Oftentimes, due to time constraints during the assessment process, many clinicians prefer to gather a small sample of the child's spontaneous speech rather than administer the second portion of the Goldman-Fristoe Test of Articulation-2. By assessing their sound production in connected speech clinicians are able to account for other factors such as coarticulation. Many experts agree that a spontaneous sample must be obtained in order to gain a complete and thorough diagnosis. Velleman (1998) warns clinicians that these tests were designed to assess segmental errors only and therefore have limitations.

\section{$\underline{\text { Bilingual Assessments }}$}

The assessment of bilingual children has become one of the most intriguing matters in the field of communication sciences and disorders. There is a limited amount of tools that are commercially available for assessing the phonological development of bilingual children. In addition, few norms are available for the children acquiring two languages (Goldstein and Washington, 2001). Yavas (2003) agrees "there's a desperate need for information on phonological development in bilingual children and assessment procedures unique to these individuals" (p.118). Because of the lack of testing materials and established normative data on certain languages, many clinicians tend to perform phonological assessments for bilingual children using monolingual assessments tools that were normed on different populations. According to Goldstein (2000), in assessing individuals from culturally and linguistically diverse populations modifications should 
me made to the typical assessment process. Therefore, clinicians must have alternate means of assessments rather than relying on standardized tests that do not include the particular culture of the client in question.

Peña-Brooks and Hegde (2000) provide clinicians working with children of dual phonological repertoire a list of important information to consider. They stress that the clinician must "understand the characteristics of the child's first language, including phonological, morphologic, syntactic and pragmatic features and how they contrast with those of English" (p. 239). Moreover, Yavas (2003) suggests that when assessing a bilingual child both languages must be examined in detail even if the child appears to be dominant in one of the languages. Just as in assessing the phonological repertoire of a monolingual child, the phonemes in the bilingual child's repertoire should be assessed in all possible positions in that language. Thus, clinicians must ensure that bilingual children receive the quality of assessment procedures as monolingual English-speaking. 


\section{Questions}

Q1. What are the differences and similarities in production of coexisting Creole and English phonemes produced by bilingual Haitian children?

Q2. Do bilingual Haitian American children acquire $85 \%$ of the Haitian Creole and English phonemes between the ages of three and five compared to monolingual children do?

\section{Hypotheses}

H1. There are no significant differences in the production of coexisting phonemes by individual bilingual children using Haitian Creole/English words.

H2. There are no significant differences in the phonemic repertoires of the group of bilingual Haitian Creole/ English children tested at age three compared to the group tested at age five. 
Chapter 3

\section{METHODOLOGY}

\section{Participants and settings}

This study consisted of forty normally developing participants of low socioeconomic groups from the North and Central Miami areas. Informed consents were obtained prior to parents filling out a Home Language Questionnaire (see appendix 3-6 for content). Participants were selected based on the responses from the Home Language Questionnaire given to their legal guardians about their ethnic background and languages spoken in the home. Home Language Questionnaires were made available to parents/guardians in both Haitian Creole and English (see appendix 3-6 for content). Participants mainly consisted of students enrolled in local child care programs. Participants were three years old and five years old, twenty boys and twenty girls of Haitian background. The age of the participants who were three years old ranged from three years two months to three years eleven months. The five-year-old participants were between the ages of five years one month to five years eleven months (See Table 1 for characteristics of the participants).

\section{TABLE 1}

\section{Characteristics of the participants}

\begin{tabular}{|c|c|c|c|}
\hline & 3 year-olds & 5 year-olds & Total \\
\hline$>\mathbf{8}$ hours daily & $2 / 2$ & $1 / 6$ & $3 / 8$ \\
\hline$<\mathbf{8}$ hours daily & $8 / 8$ & $8 / 5$ & $16 / 13$ \\
\hline Total & $10 / 10$ & $9 / 11$ & $19 / 21$ \\
\hline
\end{tabular}

Note. Time exposed to Creole is presented in two groups: more than 8 hours daily, and less than 8 hours daily. The ratio male/female is presented in each cell for the younger ( 3 years) and older ( 5 years) participants. 
Participants were compensated for their involvement by selecting a toy or an assortment of stickers. All participants passed a 25 or $30 \mathrm{~dB}$ pure tone hearing-screening test at 500 , 1000,2000 , and $4000 \mathrm{~Hz}$. In addition, all participants were given an oral mechanism screening to assess structures and function. In a quiet room, each child was tested individually in a 30-45- minute-session.

\section{Eligibility Criteria}

A significant factor in the participants' eligibility to participate in the study was their level of bilingualism. To determine whether a child was considered bilingual, responses from the Language Questionnaire given to the parents/guardians were analyzed. Criteria required the home language of participants to be Haitian Creole, additionally, each child had to be exposed to both languages during a typical twelvehour-day. For the purpose of calculating whether the amount of exposure to each language was a factor in the participants' performances during the evaluations, parents/guardians were asked to report how many hours in a twelve-hour-day were the participants exposed to each language (Figure 1). In analyzing these responses, $45 \%$ of the participants $(\mathrm{N}=18)$ were exposed to English less than eight hours per day while $55 \%$ $(\mathrm{N}=22)$ were exposed to English eight or more hours per day. The amount of hours exposed to Haitian Creole was significantly different from those hours exposed to English. Results indicated that $22.5 \%$ of the participants ( $N=9$ ) were exposed to Creole less than eight hours while an increasing amount of $77.5 \%$ of the participants $(\mathrm{N}=31)$ were exposed to Creole more than eight hours during a typical day. Thus, concluding that the participants in the study had more exposure to Haitian Creole than to English. 
Some of the parents/guardians reported that the participants' only exposure to English had been when in school/daycare.

\section{Figure 1. Percentage of hours exposed to English compared to Haitian Creole}

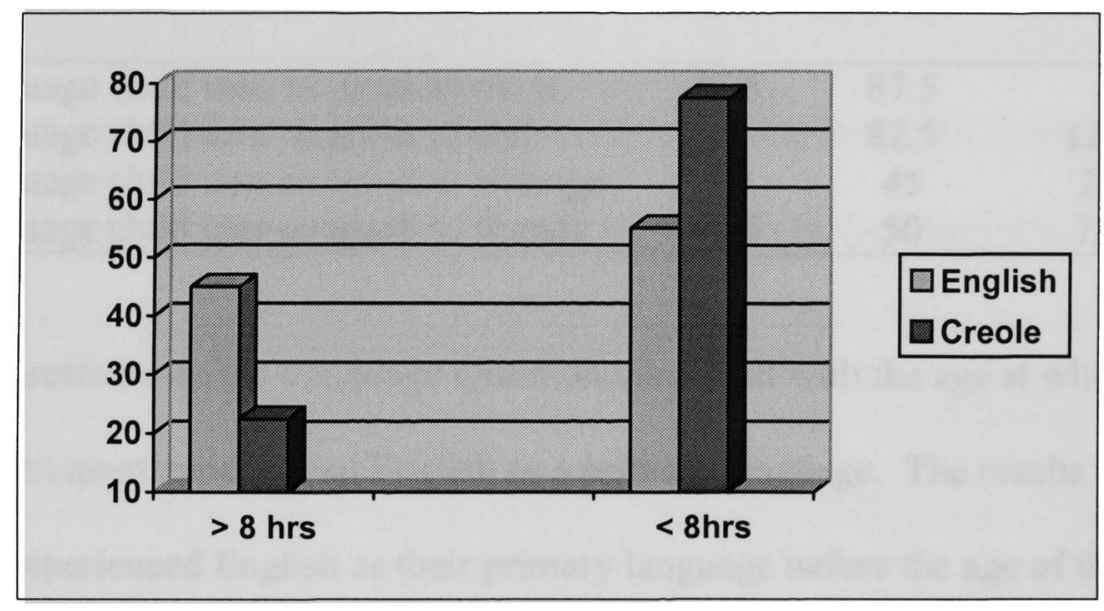

Upon analyzing the responses from the questionnaires, results showed that all participants $(\mathrm{N}=40)$ were exposed to both languages. In addition, all participants $(\mathrm{N}=40)$ spoke Creole at home and all participants learned Creole as their first language. Results showed that most of the participants used Creole when speaking to the mothers $(12.5 \%$ chose English; $87.5 \%$ chose Creole) (Table 2). Amongst the participants, $12.5 \%$ were reported to have no father or male involvement in their homes; however, of the participants who had adult male interactions in the home, only $5 \%$ chose English as the main language to address their fathers or father figures. In addressing siblings, $30 \%$ of the participants spoke using English while $45 \%$ chose Creole; the remaining $25 \%$ did not have siblings. When asked which language the participants used to speak to friends, $50 \%$ answered Creole while $42.5 \%$ indicated English. Some parents reported that their child had no interactions with friends outside of the school setting, which accounted for the remaining $7.5 \%$. 


\section{TABLE 2}

\section{Percentage of time participants spoke English and Haitian Creole}

\begin{tabular}{|lccc|}
\hline & $\begin{array}{c}\% \\
\text { English }\end{array}$ & $\begin{array}{c}\% \\
\text { Creole }\end{array}$ & $\begin{array}{c}\text { Not } \\
\text { Applicable }\end{array}$ \\
\hline Language child uses to speak to mom & 12.5 & 87.5 & - \\
Language child uses to speak to dad & 5 & 82.5 & 12.5 \\
Language child uses to speak to siblings & 30 & 45 & 25 \\
Language child uses to speak to friends & 42.5 & 50 & 7.5 \\
\hline
\end{tabular}

One of the questions on the Language Questionnaire dealt with the age at which the bilingual participant experienced English as a primary language. The results indicated that $67.5 \%$ experienced English as their primary language before the age of three while $32.5 \%$ reported that the participants experienced English as their primary language between the ages of three and five.

Instruments

Participants were tested using the Sounds-in Words subtest of the GoldmanFristoe Test of Articulation- 2. During the examination, the examiner only spoke English to elicit the production of English phonemes. When the participants attempted to use Creole words, they were redirected by the examiner to use English Words. The first section of the Goldman-Fristoe Test of Articulation-2 consisted of 53 target words to elicit the articulation of 61 consonants. The consonants were assessed in initial, medial, and final word positions. Twenty-three of the twenty-five sounds of the Standard English consonants were assessed in the GFTA-2 (Goldman and Fristoe, 2000). The sounds /hw/ and /3/ were not assessed due to their lack of occurrence in Standard English. In addition, 16 consonant clusters were elicited only in initial word position. 
Next, the participants were tested using the Haitian Creole Picture Naming Assessment with a similar format to the GFTA-2. The instrument assessed Haitian Creole phonemes in initial, medial and final word positions. During the administration of the Creole assessment, the examiner only spoke in Creole. When the participants attempted to use English words, they were redirected by the examiner to use Creole Words. Twenty-three Haitian Creole consonantal phonemes were assessed. In addition, eighteen initial consonant clusters were tested in Haitian Creole. Selected pictures were used to elicit target words. Pictures were taken from a variety of colored flashcard sets and arranged in a binder in order to replicate the format of the GFTA-2. If the child did not respond to the stimuli spontaneously, additional cues including questions, prompts, and delayed imitation were given.

\section{$\underline{\text { Data Collection }}$}

Participants were audiotaped with a portable microcassette recorder placed next to them. Response forms were used for data collection with participants' identifying information. Data were collected using the response form for all phonemes in initial, medial, and final word positions (see appendix 8 and 9 for Data Collection Forms). All phonemes were transcribed phonetically by the examiner using the International Phonetic Alphabet. Articulation errors such as substitutions, omissions, deletions, and additions were noted on the response sheet.

\section{$\underline{\text { Statistical Analysis }}$}

The audiotape materials were transcribed using the International Phonetic Alphabet (IPA). The data were tabulated by age and sex to determine the percentage of
children who produce each consonant phoneme correctly. The data were coded and 
analyzed using the SPSS Program. In addition, the data analysis for this research was conducted using ANOVA to analyze the significance of different variables and their interactions. Inferential statistical tests such as paired sample t-tests and independent sample t-tests were calculated to determine significant differences between variables. The collected data were compared to established normative articulation data from the Goldman-Fristoe Test of Articulation- 2 using frequency calculations. 


\section{Chapter 4}

\section{RESULTS}

The purpose of this study was to gather normative data of the phonological system of bilingual Creole-English Haitian American children ages three and five living in south Florida and compare their performances to already established normative data for monolingual English speaking children. Forty normally developing bilingual participants of low socio-economic groups from the North and Central Miami areas were chosen to complete this study. Participants were tested using the Sounds-in Words section of the Goldman-Fristoe Test of Articulation-2 and a Haitian Creole picture naming assessment with a format similar to the GFTA-2. Data was collected using a response form for all phonemes in word positions initial, medial, and final. The hypotheses of the study were as followed:

H1. There are no significant differences in the production of coexisting phonemes by bilingual children using Haitian Creole words compared to English wordsAccepted.

H2. There are no significant differences in the phonemic repertoires of the group of bilingual Haitian Creole/ English children tested at age three compared to the group tested at age five- Rejected.

Phonological repertoire of coexisting phonemes

In this study, the data were analyzed in terms of the percentages of correct production of English phonemes compared to the production of the same phonemes in Creole. English and Creole share 20 coexisting phonemes (see appendix for matrix of consonants). In addition, the overall percent of accuracy of all phonemes in all word 
positions for the two age groups were also analyzed. Further analysis was completed to determine whether differences in accuracy between boys and girls existed. Moreover, the overall percentages of correct production of all phonemes were compared with incorrect production of the target phonemes. The incorrect productions of all phonemes were further analyzed and coded as: substitution, omission, distortion, or addition errors. The 22 phonemes in Creole and the 23 phonemes in English (see appendix 1 for matrix of consonants) were analyzed based on frequency of occurrence in initial, medial, and final positions of words. Phonemic clusters in both languages were also analyzed; 16 in English and 18 in Creole. However, the phoneme /3/ was only tested in Creole due to its low frequency of occurrence in English.

The overall percentage of coexisting phonemes was analyzed. The results indicated that the percentage of correct production in Haitian Creole $(\underline{\mathrm{M}}=91.59, \underline{\mathrm{SD}}=$ 6.52) had no significant difference $(\mathrm{p}=.264)$ when compared to the percentage of correct production of the same phonemes in English $(\underline{\mathrm{M}}=92.78, \underline{\mathrm{SD}}=8.16)$. In addition, each of the coexisting phonemes was analyzed in initial, medial, and final word positions. A paired sample t-test was conducted to compare the percentages between the Haitian Creole production and the English production. In the initial position, the correct productions in Haitian Creole $(\mathrm{M}=97.37, \underline{\mathrm{SD}}=4.13)$, and the correct productions in English $(M=97.22, \underline{S D}=5.63)$ had no statistical significance $(p=.858)$. The percentages of correct production in Haitian Creole of coexisting phonemes in medial position $(\mathrm{M}=96.32, \underline{\mathrm{SD}}=5.74)$ and the correct production of English phonemes in medial position $(\mathrm{M}=96.47, \underline{\mathrm{SD}}=5.62)$ also had no statistical significance $(\mathrm{p}=.878)$. However, results revealed that the percentage of correct production in Haitian Creole phonemes in the final 
position $(M=95.00, \underline{\mathrm{SD}}=8.05)$ when compared to the percentage of correct production of the same phonemes in English $(M=91.76, \underline{S D}=10.89)$ was statistically significant $(p=$ .012). A statistical significance $(p=.001)$ was also noted upon the analysis of correct production of Haitian Creole clusters $(\mathrm{M}=68.18, \underline{\mathrm{SD}}=21.69)$ and the percentage of correct production of clusters in English $(\mathrm{M}=81.36, \underline{\mathrm{SD}}=20.06)$ (Table 3).

\section{TABLE 3}

Percentage of Correct Production of coexisting phonemes

\begin{tabular}{|lccccc|}
\hline & \multicolumn{2}{c}{$\begin{array}{c}\text { Haitian Creole } \\
\mathbf{N}=\mathbf{2 0}\end{array}$} & \multicolumn{2}{c|}{$\begin{array}{c}\text { English } \\
\mathbf{N}=\mathbf{2 0}\end{array}$} & p value \\
\hline Overall & $\underline{\mathbf{M}}$ & $\underline{\mathbf{S D}}$ & $\underline{\mathbf{M}}$ & $\underline{\mathbf{S D}}$ & \\
Initial Position & 97.59 & 6.52 & 92.78 & 8.16 & .264 \\
Medial Position & 96.32 & 4.13 & 97.22 & 5.63 & .858 \\
Final Positions & 95.00 & 8.05 & 96.47 & 5.62 & .878 \\
Clusters & 68.18 & 21.69 & 81.36 & 10.89 & $.012^{*}$ \\
\hline
\end{tabular}

*= Statistical Significance

The results of this study indicated no significant differences in the overall production of coexisting phonemes in initial and medial positions of words; however, a significant difference was evident in the final position of the coexisting phonemes.

\section{Age of acquisition of Haitian Creole consonants}

In the overall sample, $50 \%$ of the participants were three years old $(\mathrm{N}=20)$ and the other $50 \%$ were five years old $(\mathrm{N}=20)$. The age of the participants who were three years old ranged from three years two months to three years eleven months. The fiveyear-old participants were between the ages of five years one month to five years eleven months. The data were analyzed by age groups. Group A was considered to be less than four years old and Group B was more than four years old. Overall, the correct production of all phonemes was higher for the five-year olds in Haitian Creole $((\mathrm{M}=90.84$, 
$\underline{\mathrm{SD}}=5.66)$ when compared to the three-year-olds $(\mathrm{M}=85.00, \underline{\mathrm{SD}}=7.40)$. Results of an independent sample t-test revealed a statistical significance ( $p=.008)$. In addition, fiveyear-olds also had a more correct production of phonemes in English $(\mathrm{M}=90.32, \underline{\mathrm{SD}}=$ 5.17) when compared to the three-year-olds performance $(M=81.82, \underline{S D}=9.56)$. An independent sample $t$-test illustrated a statistical significance $(p=.002)$ between the performance of three-year-olds and five-year-olds in producing English phonemes.

In addition, the overall percent of correct production of all phonemes in all word positions for the two age groups were also analyzed as well as in the percentage of correct production of clusters. When tested in Haitian Creole the group of five-year-olds produced the phonemes in all three word positions in Haitian Creole when compared to the group of three-year-olds. Additionally, the group of five-year-olds produced the phonemes in all three word positions when compared to the group of three-year-olds when tested in English. An independent sample analysis was conducted to determine the statistical significance in the phonemic production in initial, medial, final word positions in English and in Creole between the two age groups. Results indicated a statistical difference between the groups bilingual Haitian Creole/ English children tested at age three compared to the group tested at age five. The group of five-year-olds participants displayed significance in medial and final positions when tested in Creole while also displaying significance in all word positions when tested in English. (Table 4) 
TABLE 4

Group differences in the phonemic production by age

\begin{tabular}{|cccccc|}
\hline & \multicolumn{3}{c}{$\begin{array}{c}\text { 3 year-olds } \\
\text { N=20 }\end{array}$} & \multicolumn{2}{c|}{$\begin{array}{c}\text { 5 year-olds } \\
\mathbf{N = 2 0}\end{array}$} \\
\hline Creole & $\underline{\mathbf{M}}$ & $\underline{\mathbf{S D}}$ & $\underline{\mathbf{M}}$ & $\underline{\mathbf{S D}}$ & $\mathbf{p}$ \\
Overall & 85.00 & 7.40 & 90.84 & 5.66 & $.008^{*}$ \\
Initial Position & 90.24 & 6.46 & 93.33 & 4.48 & .086 \\
Medial Position & 86.67 & 7.66 & 91.43 & 4.79 & $.025^{*}$ \\
Final Position & 91.76 & 9.62 & 98.24 & 4.31 & $.011^{*}$ \\
Clusters & 70.56 & 15.93 & 80.28 & 15.66 & .059 \\
English & & & & & \\
Overall & 81.82 & 9.56 & 90.32 & 5.17 & $.002^{*}$ \\
Initial Position & 84.32 & 6.83 & 88.64 & 4.30 & $.023^{*}$ \\
Medial Position & 83.00 & 7.15 & 89.00 & 5.53 & $.005^{*}$ \\
Final Position & 83.16 & 11.90 & 91.32 & 6.89 & $.012^{*}$ \\
Clusters & 75.31 & 19.07 & 93.13 & 11.27 & $.001^{*}$ \\
\hline
\end{tabular}

* = Statistical Significance

When compared to the results from the GFTA-2, the participants in this study followed the general pattern of sound acquisition in the production of Haitian Creole phonemes; however, some phonemes appeared to be mastered earlier than what research supports. According to the results the participants ranging from three years two months to three years eleven months mastered bilabial stops, labial-dental fricatives alveolar stops and velar stops in initial, medial, and final positions of words (Table 5). In addition, alveolar fricatives, palatal alveolar and palatal alveolar fricative phonemes were also mastered by the three-year-old participants. Bilabial nasal $/ \mathrm{m} /$ and bilabial glide $/ \mathrm{w} /$ were also mastered. Upon analyzing their performance in the phonological presence of the liquids, the three-year-old participants mastered the alveolar liquid /1/ in initial, medial, and final word positions. However, when analyzing the results from two phonemes not present in the English, velar approximant /ul/ (also referred to by some 
researchers as velar /fricative $/ \mathrm{\gamma} /$ ) and bilabial glide $/ 4 /$, less than $85 \%$ of the three-yearold participants as well as the five-year-olds produced the phonemes correctly (Table 5).

\section{TABLE 5}

\section{Age of mastery for Haitian-Creole Consonants}

\begin{tabular}{|c|c|c|c|c|c|c|}
\hline & \multicolumn{2}{|c|}{ SIWI } & \multicolumn{2}{|c|}{ SIWW } & \multicolumn{2}{|c|}{ SFWF } \\
\hline & \multicolumn{2}{|c|}{$\begin{array}{c}3 y r s \quad 5 y r s \\
\%\end{array}$} & \multicolumn{2}{|c|}{$\begin{array}{c}\text { 3yrs } 5 y r s \\
\%\end{array}$} & \multicolumn{2}{|c|}{$\begin{array}{c}\text { 3yrs } \\
\%\end{array}$} \\
\hline p & 100 & 100 & 97.5 & 100 & 97.5 & 100 \\
\hline b & 97.5 & 100 & 97.5 & 100 & 92.5 & 100 \\
\hline $\mathbf{t}$ & 100 & 100 & 100 & 100 & 97.5 & 100 \\
\hline d & 100 & 100 & 100 & 100 & 90 & 100 \\
\hline $\mathbf{k}$ & 100 & 100 & 100 & 100 & 95 & 100 \\
\hline g & 95 & 100 & 100 & 100 & 95 & 100 \\
\hline f & 100 & 100 & 100 & 100 & 100 & 100 \\
\hline $\mathbf{v}$ & 95 & 100 & 100 & 100 & 100 & 100 \\
\hline $\mathbf{S}$ & 97.5 & 100 & 100 & 100 & 97.5 & 100 \\
\hline $\mathbf{z}$ & 97.5 & 100 & 95 & 100 & 85 & 100 \\
\hline $\int$ & 97.5 & 100 & 95 & 100 & 90 & 100 \\
\hline & 92.5 & 100 & 90 & 100 & 87.5 & 100 \\
\hline$t \int$ & 92.5 & 100 & 92.5 & 97.5 & & \\
\hline d3 & 90 & 97.5 & 97.5 & 97.5 & & \\
\hline $\mathbf{m}$ & 100 & 100 & 100 & 100 & 100 & 100 \\
\hline $\mathrm{n}$ & 97.5 & 100 & 97.5 & 100 & 100 & 100 \\
\hline 1 & 100 & 100 & 100 & 100 & 100 & 100 \\
\hline $\mathbf{y}$ & & & & & 90 & 92.5 \\
\hline 따 * & 60 & 90 & 50 & 70 & & \\
\hline $\mathbf{w}$ & 100 & 100 & 100 & 100 & & \\
\hline $\mathbf{j}$ & 97.5 & 100 & 75 & 90 & 100 & 100 \\
\hline $\mathrm{Y}^{*}$ & 7 & 10.5 & 6 & 9 & & \\
\hline
\end{tabular}

* = Phonemes that are present only in Haitian Creole

The analysis of the phoneme production in English revealed the following results.

The participants ranging from three years two months to three years eleven months mastered the bilabial stops, labial-dental fricatives (except for $/ \mathrm{v} /$ in medial word 
position), alveolar stops (except for/d/ in final word position), and velar stops in initial, medial, and final positions of words. Although the $/ \mathrm{h} /$ phoneme does not exist in Haitian Creole, only one of the participants omitted the phoneme when tested in English. In addition, alveolar fricatives, palatal alveolar and palatal alveolar fricative phonemes were also mastered by the three-year-old participants. Bilabial nasal $/ \mathrm{m} /$ and bilabial glide $/ \mathrm{w} /$ were also mastered. Upon analyzing their performance in the phonological presence of the liquids, the three-year-old participants mastered the alveolar liquid /1/ in initial, medial word positions; however it was not mastered in final word position until the age of five. The alveolar liquid /r/ was only mastered in the final word position by both age groups. It was not mastered by the three-year-old participants either in initial nor medial word positions. From the forty participants, only two were able to produce the English phonemes $/ \theta /$ and $/ \delta /$.

\section{Post-hoc Analysis}

\section{Performance-based exposure}

Several post hoc analyses were conducted with the collected data. An independent sample t-test was conducted to assess the performances of the children based on the amount of exposure in the two languages. In analyzing the performances of the children who were exposed to English eight or more hours, their performances were better when evaluated in English. Participants with less than eight hours exposure to English correctly produced English phonemes less than $85 \%$ of the time $(\mathrm{M}=84.20$, $\underline{\mathrm{SD}}=10.92$ ); whereas, participants with eight or more hours exposure to English correctly produced English phonemes more than $85 \%$ of the time $(\underline{\mathrm{M}}=87.54, \underline{\mathrm{SD}}=6.31)$. The same analysis was conducted with the performances of children exposed to Creole. Results 
illustrated that mathematically the children exposed to less than eight hours to Creole performed better when evaluated in Creole. Their overall performance in Creole yielded the following results. Participants with less than eight hours exposure to Creole correctly produced Creole phonemes more than $90 \%$ of the time $(\underline{\mathrm{M}}=90.62, \underline{\mathrm{SD}}=6.15)$; whereas, participants with eight or more hours exposure to Creole correctly produced Creole phonemes less than $90 \%$ of the time $(\underline{\mathrm{M}}=87.14, \underline{\mathrm{SD}}=7.31)$ (Figure 2). However, no statistical significance was noted with the children's performances in either Creole $(p=0.838)$ or English $(p=0.260)$ based on the amounts of exposure to either language.

\section{Figure 2. Language performance based on length of exposure to each language}

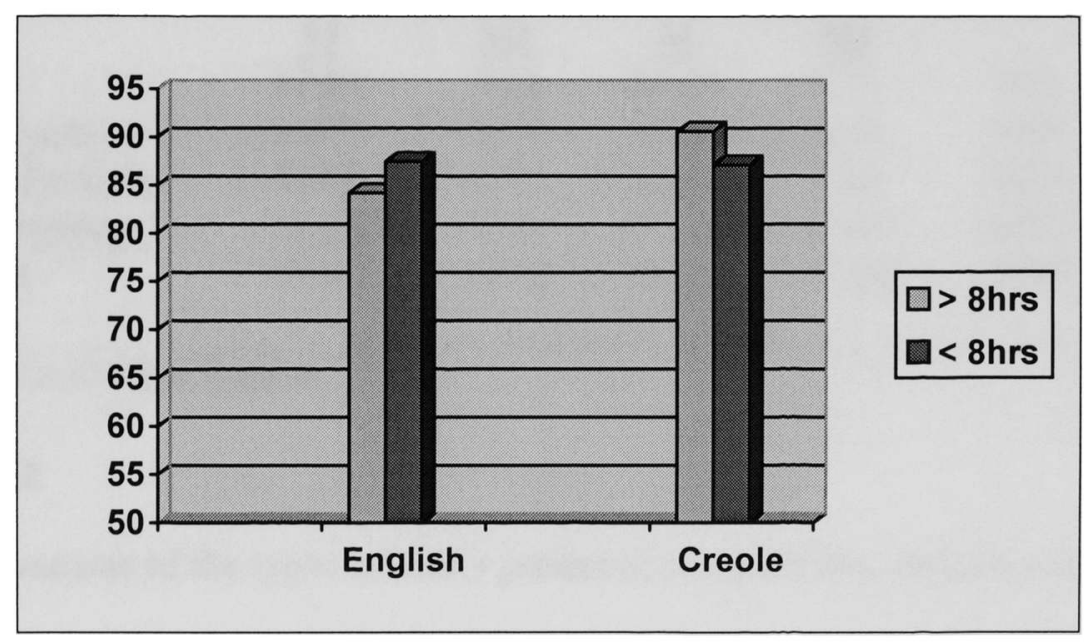

Percentage of correct Haitian Creole phones produced compared to English

In addition, as part of the post hoc analysis, the percentage of all correct phonemes produced in English was compared to the percentage of all correct phonemes produced in Haitian Creole. The results indicated that the mean number of correct Haitian Creole phonemes $(\underline{\mathrm{M}}=87.92, \underline{\mathrm{SD}}=7.14)$ was greater than the mean number of correct English phonemes $(\underline{\mathrm{M}}=86.03, \underline{\mathrm{SD}}=8.73)($ Table 6). A paired sample t-test was conducted to further assess whether the correct production of phonemes in all positions of 
English and Creole were statistically significant. The results concluded that the overall percentage of phonemes produced correctly in both languages displayed no statistical difference $(\mathrm{p}=.083)$. However, the results revealed a statistical significance in the production of phonemes in both languages in initial $(p=.000)$, medial $(p=.009)$ and final $(\mathrm{p}=.000)$ word positions. In addition, the percentage of correct production between English and Creole phonemic clusters also displayed a statistical significance $(p=.005)$.

TABLE 6

Mean Percentage of Correct Production of all phonemes

\begin{tabular}{|lccccc|}
\hline & \multicolumn{2}{c}{$\begin{array}{c}\text { Haitian Creole } \\
\mathbf{N}=\mathbf{2 2}\end{array}$} & \multicolumn{2}{c|}{$\begin{array}{c}\text { English } \\
\mathbf{N = 2 3}\end{array}$} & p value \\
\hline & $\underline{\mathbf{M}}$ & $\underline{\mathbf{S D}}$ & $\underline{\mathbf{M}}$ & $\underline{\mathbf{S D}}$ & \\
Overall & 87.92 & 7.14 & 86.04 & 8.73 & .083 \\
Initial Position & 91.79 & 5.70 & 86.48 & 6.04 & $.000^{*}$ \\
Medial Position & 89.05 & 6.75 & 85.87 & 7.06 & $.009^{*}$ \\
Final Positions & 95.00 & 8.05 & 87.24 & 10.45 & $.000^{*}$ \\
Clusters & 75.41 & 16.35 & 84.22 & 17.90 & $.005^{*}$ \\
& & & & & \\
\hline
\end{tabular}

* = Statistical Significance

\section{$\underline{\text { Analysis of errors }}$}

Further analysis of the types of errors produced revealed that, substitution was the most common error type in both languages. A paired sample t-test was conducted to compare the types of errors in each of the languages with all phonemes. When the phonemes were analyzed, the participants displayed a higher frequency of substitution errors in Haitian Creole $(\underline{\mathrm{M}}=5.34, \underline{\mathrm{SD}}=4.32)$ than they did in English $\quad(\underline{\mathrm{M}}=5.22, \underline{\mathrm{SD}}$ $=6.27)$. Omission errors were more common in Haitian Creole $(\underline{\mathrm{M}}=3.29, \underline{\mathrm{SD}}=2.73)$ than in coexisting English phonemes $(\underline{\mathrm{M}}=1.98, \underline{\mathrm{SD}}=2.84)$. However, distortion errors and addition errors were the least common types of errors produced in both English and 
Haitian Creole upon the analysis of all phonemes. Distortion errors occurred in English $(\underline{\mathrm{M}}=.17, \underline{\mathrm{SD}}=.77)$ while they did not occur in Haitian Creole $(\underline{\mathrm{M}}=.000, \underline{\mathrm{SD}}=.000)$.

Results indicated that addition errors occurred more frequently in Haitian Creole $(\underline{\mathrm{M}}=$ $.24, \underline{\mathrm{SD}}=.66)$ than they did in English $(\underline{\mathrm{M}}=.07, \underline{\mathrm{SD}}=.33)$. In addition, a paired sample t-test was conducted to determine the statistical significance between the types of errors produced in English compared to the same types of errors produced in Creole. The participants' omission errors were the only error type to yield a statistical difference with $\mathrm{p}=.002$. Although the other errors showed a mathematical significance, they were not statistically significant (Tables $7 / 8$ )

\section{TABLE 7}

\section{Percentage of errors with all Creole phonemes}

\begin{tabular}{|cccccccccccccc|}
\hline & \multicolumn{1}{c}{ Substitution } & \multicolumn{4}{c}{ Omission } & \multicolumn{4}{c|}{ Distortion } & \multicolumn{3}{c|}{ Addition } \\
\hline & $\underline{\mathbf{M}}$ & $\underline{\mathbf{S D}}$ & $\mathbf{p}$ & $\underline{\mathbf{M}}$ & $\underline{\mathbf{S D}}$ & $\mathbf{p}$ & $\underline{\mathbf{M}}$ & $\underline{\mathbf{S D}}$ & $\mathbf{p}$ & $\underline{\mathbf{M}}$ & $\underline{\mathbf{S D}}$ & $\mathbf{p}$ \\
Overall & 5.34 & 4.32 & .885 & 3.29 & 2.74 & $.002^{*}$ & .000 & .000 & - & .240 & .688 & .109 \\
Initial & 2.50 & 3.95 & .856 & .000 & .000 & - & .000 & .000 & - & .132 & .832 & .970 \\
Medial & 4.72 & 8.30 & .386 & 2.78 & 4.87 & $.001^{*}$ & .000 & .000 & - & .000 & .000 & - \\
Final & 3.97 & 6.01 & .062 & .882 & 2.51 & $.000^{*}$ & .000 & .000 & - & .000 & .000 & - \\
Cluster & 12.92 & 9.78 & .964 & 11.11 & 9.16 & $.000^{*}$ & .000 & .000 & - & .833 & 2.63 & .105 \\
\hline
\end{tabular}

$*=$ Statistical Significance

\section{TABLE 8}

Percentage of errors with all English phonemes

\begin{tabular}{|cccccccccccccc|}
\hline & \multicolumn{1}{c}{ Substitution } & \multicolumn{1}{c}{ Omission } & \multicolumn{4}{c|}{ Distortion } & \multicolumn{3}{c|}{ Addition } \\
\hline & $\underline{\mathbf{M}}$ & $\underline{\mathbf{S D}}$ & $\mathbf{p}$ & $\underline{\mathbf{M}}$ & $\underline{\mathbf{S D}}$ & $\mathbf{p}$ & $\underline{\mathbf{M}}$ & $\underline{\mathbf{S D}}$ & $\mathbf{p}$ & $\underline{\mathbf{M}}$ & $\underline{\mathbf{S D}}$ & $\mathbf{p}$ \\
Overall & 5.22 & 6.27 & .885 & 1.98 & 2.84 & $.002^{*}$ & .187 & .770 & .133 & .075 & .329 & .109 \\
Initial & 2.64 & 5.34 & .856 & .000 & .000 & - & .000 & .000 & - & .139 & .878 & .970 \\
Medial & 3.59 & 5.81 & .386 & .000 & .000 & $.001^{*}$ & .000 & .000 & - & .000 & .000 & - \\
Final & 2.35 & 4.58 & .062 & 5.59 & 7.65 & $.000^{*}$ & .294 & 1.30 & .160 & .000 & .000 & - \\
Cluster & 12.81 & 14.29 & .964 & 2.34 & 5.04 & $.000^{*}$ & .469 & 2.96 & .323 & .156 & .988 & .105 \\
\hline
\end{tabular}

$*=$ Statistical Significance 
The data were also analyzed to display any differences in the percentage of correct production of phonemes in both English and Haitian Creole by gender. Results of the independent sample t-test illustrated that there is no statistical significance in the overall percentage of correct production of phonemes neither in Creole $(p=.366)$ nor in English $(p=.095)$ (Table 9).

TABLE 9

Differences in the percentage of correct production of phonemes by gender

\begin{tabular}{|lllllllll|}
\hline & & \multicolumn{3}{c}{ Males $(\mathbf{N}=20)$} & \multicolumn{3}{c|}{ Females $(\mathbf{N}=20)$} \\
\hline Creole & & $\underline{\mathbf{M}}$ & $\underline{\mathbf{S D}}$ & $\mathbf{p}$ & $\underline{\mathbf{M}}$ & $\underline{\mathbf{S D}}$ & $\mathbf{p}$ \\
& Overall & 86.88 & 8.75 & .366 & 88.96 & 5.10 & .366 \\
& & & & & & & & \\
& Overall & 83.76 & 2.17 & .095 & 88.38 & 7.14 & .095 \\
\hline
\end{tabular}

In addition, a two-way ANOVA was conducted to verify the interaction between age and gender in both languages. The overall correct production as well as the production in each position was analyzed relative to age and gender. Results indicated that there were no statistical significance between age and gender in the overall production of Creole phonemes $(p=.855)$. Moreover, there were no statistical significance between age and gender in the overall production of English phonemes $(p=.217)$. Thus, the results do not support a statement that gender made a difference in the participants' performance. However, results indicate that the age of the participants had a direct correlation with how well they performed when tested in both languages. 


\section{Chapter 5}

\section{DISCUSSION}

The purpose of this study was to gather normative data of the phonological system of normally developing bilingual Creole-English Haitian American children ages three and five living in south Florida. In addition, their performances were compared to already established normative data for monolingual English speaking children. This information is essential for professionals who work with bilingual Haitian American children in terms of evaluation and treatment. To date, there are no known studies that have addressed the dual acquisition of Haitian Creole and English in preschool children. Studies that were cited and analyzed for this research focused on the combination of other languages and English. Upon analyzing the results of this study, hypothesis one was accepted while hypothesis two was rejected. Both of the research questions were addressed and the results are supported by previous studies.

Q1. What are the differences and similarities in production of coexisting Creole and English phonemes produced by bilingual Haitian children?

Q2. Do bilingual Haitian American children acquire $85 \%$ of the Haitian Creole and English phonemes between the ages of three and five just as monolingual children do?

The overall results of the study revealed that the phonological development in bilingual Haitian American children displayed similar patterns to that of other bilingual children. Moreover, the group of five-year-old participants performed with a higher level of correct phoneme production compared to the group of three-year-old participants. 
The coexisting phonemes were analyzed in the initial, medial, and final positions of words for both languages. Results illustrated no significant findings in initial or in medial positions. However, findings in the final positions were significant. This could be attributed to the fact that the sound distribution in Haitian Creole is different than that of English. According to Cadely (2004), the phonemes /b/, /d/, and $/ \mathrm{\gamma} /$ are the only phonemes in the inventory that present with "interruption" in terms of distribution. The phonemes $/ \mathrm{b} /$ and $/ \mathrm{d} /$ do not occur in the final position of words following a nasal vowel. Moreover, the velar fricative $/ \mathrm{y} /$ does not appear in the final position of words or in the environment of rounded vowels such as $/ \mathrm{o} /, / \mathrm{o} / \mathrm{and} / \mathrm{u} /$. Thus, one may conclude that phonemic distribution in final position of words in Haitian Creole is more restrictive than it is English. Although English and Haitian Creole share some clusters in the initial position of words, they were not analyzed as coexisting but rather as a group. Significant differences were also evident in the analysis of clusters in both languages.

Research conducted with monolinguals have set the standards for phonological development. According to Yavas (1998) at the systematic stage following the 50-wordstage, the child develops a phonological system in which most of the phonemes are established. Furthermore, the research of Stoel-Gammon and Dunn (1985) supported the notion that by age three children master the phonemes $/ \mathrm{p} /, / \mathrm{m} /, / \mathrm{n} /, / \mathrm{w} /$, and $/ \mathrm{h} /$ whereas mastery productions for $/ \mathrm{b} /, / \mathrm{d} /, / \mathrm{k} /, / \mathrm{g} /, / \mathrm{f} /$, and $/ \mathrm{j} /$ usually occur by age four. However, Yavas (1998) argued that the phoneme / $t$ / is acquired and mastered earlier than the age Stoel-Gammon and Dunn reported in their 1985 study. 
In addition, many researchers have conducted studies on bilingualism and their results have yielded similar patterns to the research on monolinguals. Goldstein and Washington's (2001) study on the phonological patterns of Spanish-English bilingual children revealed that there were no significant differences in the percentage of correctly produced consonants between English and Spanish. According to the results of this study, the phonological development of Haitian Creole phonemes reflects the established pattern of development in sound acquisition. Sound classes such as stops, nasals, and glides were all mastered by age five. However, most errors occurred with liquids, fricatives, and affricates just as previous research studies had demonstrated. Thus, concluding that monolingual children and bilingual Haitian Creole/English children display similar patterns in acquiring phonemes.

Another phenomenon that is usually present in bilinguals is code mixing. Arnberg (1987) defines the term code switching, interchangeably used with code mixing, as the "conscious and/or purposeful switching of the two languages" (p.27). Code mixing was a key element in the developing systems of the participants in this study. Participants in this study displayed extended periods of code mixing. These findings are supported by Arnberg's (1987) views on code switching, which claim that code switching occurs as a lack of vocabulary items in one of the languages. This was apparent when many of the participants used the Haitian Creole words to name some of the stimulus items on the Goldman Fristoe Test of Articulation-2 and the same was evident during the administration of the Haitian Creole test. During those periods of code switching, the examiner found it necessary to use delayed imitation by modeling the target word in the respective language. 
Moreover, code mixing occurred more when the participants were evaluated in their non-dominant language, a behavior that is supported by research conducted by Genese, Nicoladis, and Paradis (1995). Some participants displayed more code mixing episodes when tested in Creole. In the sample, $72.5 \%$ were exposed more to Creole more than eight hours during a typical day while 25\% had more English exposure during the day. One of the reasons that may account for the high amount of exposure to Haitian Creole is that in most low socio-economic status (SES) homes the father figures are often absent and for that reason, $87.5 \%$ of the participants preferred to speak to their mothers/female guardians in Haitian Creole; usually a common practice in bilingual/bicultural homes. Thus, it can be concluded that Haitian Creole was the dominant language for most of the participants.

Studies conducted in language acquisition have also discussed the type of errors that are common when a child is acquiring a language. Results of this study revealed that substitution errors were more prevalent than other types of errors. The participants often substituted one phoneme in the place of another. The results revealed that distortion and addition errors were the least types of errors that occurred. These findings are also supported by research since distortion and addition errors are usually more common in disordered children. Furthermore, the Markedness Theory (Major, 2000), which claims that the statistical frequency is considered to be a direct correlation to markedness is also supported in this study. The theory further claims that if certain phonemes appear more often in a language the phonemes that appear more frequently will be acquired earlier than those that appear less frequently. In addition, Velleman (1998) claims the ease of 
production and the ease of perception are important factors attributing to the substitution errors that are common in bilingual speakers.

The Markedness Phenomena (Major, 2000) is further supported in this research. From the forty participants, only two were able to produce the marked phonemes $/ \theta$ / and $/ \delta /$. Thus, these phonemes accounted for some of the lower raw scores on the English portion of the assessment for the bilingual children. Although these two phonemes are not mastered prior to age seven, a Haitian Creole speaking child may take longer to acquire these phonemes given that they are not part of their Haitian Creole repertoire.

Participants from both age groups in this study displayed significant differences in their phonological repertoires. These findings are supported by the various researches conducted on the bilingual acquisition of sounds (Bruck and Genesee, 1995; Genesee, Nicoladis and Paradis, 1995; Goldstein and Washington, 2001; Haznedar, 2001; Goldstein and Iglesias, 1998; Yavas and Goldstein, 2004). Just as prior studies focused on phonological acquisition, the analysis in this study was performed with both age groups using all the phonemes in English and in Haitian Creole in all three positions of words. The overall difference displayed between the two age groups was statistically significant in Haitian Creole ( $\mathrm{p}=.008)$ and in English $(\mathrm{p}=.002)$. However, there was no significance noted in the production of Creole phonemes produced in initial position of words or in the production of clusters between the groups of three-year-olds and the fiveyear-olds (refer to Table 4 Chapter 4). However, the production of phonemes in initial, medial, and final position of words in English displayed significant differences. Thus, this study supports the recommendations of Yavas (1998) and Grunwell (1987) that when 
assessing phonemic acquisition, all distributions must be taken into consideration in order to obtain a more accurate picture.

\section{$\underline{\text { Limitations }}$}

Due to the paucity of studies that address the dual acquisition of Haitian Creole and English in children, it is not possible to determine whether the findings of this study are consistent with previous studies. This study only assessed the phonological development of a controlled group of forty typically developing children. Additional studies should also include 4 year-olds in order to gain a more detailed comparison. Another limitation to this study was the accuracy of answers on the Language Questionnaires given by the parents/guardians. Because the child is not always in the presence of the parent/guardian, it was difficult for them to determine the amount of exposure the child actually has in each of the languages. This is apparent in the results obtained as part of the post hoc analysis. The participants who were exposed to Creole less than eight hours in a typical twelve-hour-day unexpectedly performed at a higher level than the participants who were exposed to Creole more than eight hours.

Studies similar to this one can only serve as initial research for the bilingual Haitian American preschool population. In addition, the limited number of bilingual articulation assessment tools available and the lack of normative data in many languages combine to create a challenging situation for professionals that assess the speech patterns of young children. Velleman (1998) cautioned clinicians that tests like the GoldmanFristoe Test of Articulation have limitations because they are designed to assess segmental errors and do not address errors found in connected speech. However, many 
speech pathologists must rely on these assessments to establish a basis for articulation errors often displayed in the speech of young children.

$\underline{\text { Implications }}$

Further research would facilitate accuracy of diagnosis and treatment of Haitian Americans living throughout the United States especially in regions such as South Florida where the population is concentrated. The results of this study reveal that bilingual Haitian American children display the similar patterns in their phonological systems when compared to monolinguals. It would be beneficial to obtain a detailed analysis of the types of errors exhibited by bilingual Creole/English Haitian American children to serve as a mean of comparison between the types of errors exhibited by monolingual children. It would also aid to conduct further research with Haitian Creole clusters given significance differences in the production of clusters.

Until more bilingual assessment tools become commercially available, Goldstein (2000) suggested that clinicians who assess bilingual children should be willing to make the proper modifications to the available standardized tools and find alternative means of assessment for bicultural and bilingual children. The present study further supports Goldstein's recommendation. In addition, other methods such as spontaneous speech samples must accompany articulation assessment tools to account for errors not displayed in segments. 


\section{REFERENCES}

American Speech-Language Hearing Association. (1983). Position paper of the American Speech-Language Hearing Association on social dialects. ASHA, 25 (9), 23-27.

Anderson, R., \& Smith, B. (1987). Phonological development of two-year-old monolingual Puerto Rican Spanish-speaking children. Child Language, 14, 57-78.

Arnberg, L. (1987). Raising Children Bilingually: The Pre-school Years. Clevedon: Multilingual Matters Ltd.

Bernthal, J. E., \& Bankson, N.W. (1998). Articulation and Phonological Disorders. Boston: Allyn and Bacon.

Bruck, M., \& Genesee, F. (1995). Phonological awareness in young second language learners. Child Language, 22, 307-324.

Cadely, J.R. (1988). L'opposiition / $\gamma /: / \mathrm{w} /$ en Créole Haïtien. Canadian Journal of Linguistics, 33, (2), 121-142.

Cadely, J.R. (2004). Les sons du Créole Haïtien. (The sounds of Haitian Creole)

Dejean, Y. (1977). Comment écrire le Créole d'Haïti. (How to write Haitian Creole) Doctorate Dissertation. Indiana University.

Elbert, M., \& McReynolds, L. (1979). Aspects of phonological acquisition during articulation training. Journal of Speech and Hearing Disorders, 44, (4), 459-471.

Ferere, G.A. (1979). Haitian Creole: Sound-System, Form-Classes, Texts. (ERIC Document Reproduction Service No. ED 172 579).

Genesee, F. (1989). Early bilingual development: One language or two? Journal of Child Language, 16, 161-179.

Genesee, F., Nicoladis, E., Paradis, J. (1995). Language differentiation in early bilingual development. Child Language, 22, 611-631.

Goldman, R., \& Fristoe, M. (2000). Goldman-Fristoe Test of Articulation. Minnesota: American Guidance Services.

Goldstein, B., \& Iglesias, A. (1998). Phonological production in Spanish-speaking preschoolers. (ERIC Document Reproduction Service No. ED 424 935). 
Goldstein, B. (2000). Cultural and Linguistic Diversity Resource Guide for SpeechLanguage Pathologists. Singular.

Goldstein, B., \& Washington, P.S. (2001). An initial investigation of phonological patterns in typically developing 4-year-old Spanish-English bilingual children. Language, Speech, and Hearing Services in Schools, 32, 153-164.

Grunwell, P. (1985). Developing phonological skills. Child Language Teaching and Therapy, 1, 65-72.

Grunwell, P. (1987). Clinical Phonology. ( $2^{\text {nd }}$ ed.) Baltimore: Williams \& Wilkins.

Hall, R. M. R., \& Hall, B.L. (1971). A contrastive Haitian Creole-English checklist. (ERIC Document Reproduction Service No. ED 054 144).

Haznedar, B. (2001). The acquisition of the IP system in child L2 English. Studies in Second Language Acquisition, 23 (1), 1-39.

Ingram, D. (1981). Procedures for the Analysis for Children's Language. Baltimore: University Park Press.

Kenney, K., \& Prather, E. (1986). Articulation development in preschool children: Consistency of production. Journal of Speech and Hearing Reasearch, 29, 29-36.

Kritikos, E.P. (2003). Speech-Language Pathologists' beliefs about language assessment of bicultural/bilingual individuals. American Journal of Speech-Language Pathology, 12, 73-91.

Macken, M., \& Ferguson, C. (1987). Phonological universals in language acquisition. In Ioup, G., \& Weinberger, S.H. (Eds.), Interlanguage Phonology: The Acquisition of a Second Language Sound System. (p.3-22). New York: Newbury House Publishers.

Major, R.C. (2001). Foreign Accent: The Ontogony and Phylogeny of Second Language Phonology. New Jersey: Lawrence Erlbaum Associates, Publishers.

Peña-Brooks, A., \& Hegde, M.N. (2000). Assessment \& Treatment of Articulation \& Phonological Disorders in Children. Texas: Pro-ed.

Porter, J. H., \& Hodson, B.W. (2001). Collaborating to obtain phonological acquisition data for local schools. Language, Speech, and Hearing Services in Schools, 32 , 165-171.

Prather, E., Hedrick, D.L., Kern,C. (1975). Articulation development in aged two to four years. Journal of Speech \& Hearing Disorders, 40 (2), 179-191. 
Romaine, S. (1995). Bilingualism. ( $2^{\text {nd }}$ ed.) Oxford: Blackwell.

Stoel-Gammon, C. (1991). Normal and disordered phonology in two-year-olds. Topics in Language Disorders, 11, (4), 21-32.

Stoel-Gammon, C., \& Dunn, C. (1985) Normal and disordered phonology in children. Austin, TX: Pro-Ed.

Templin, M.C. (1957). Certain Language Skills in Children. Minnesota: University of Minnesota Press.

Valdman, A. (1978). Le Créole: Structure, statut et origine. Paris: Klincksieck.

Velleman, S. (1998). Making Phonology Functional: What Do I Do First. Boston: Butterworth-Heinemann.

Vernet, P. (1980). Techniques D'écriture du Créole Haïtien. Haiti: Le Natal.

Volterra, V., \& Taeschner, T. (1978). The acquisition and development of language by Bilingual children. Journal of Child Language, 5, 311-326.

Yavas, M., Hernandorena, C., and Lamprecht, R. (1991). Avaliacao fonologica da Crianca (Phonological assessment tool for Brazilian Portuguese) Porto Alegre, Brazil:Artes Medicas.

Yavas, M. (1995). Phonological Selectivity in the first fifty words of a bilingual child. Language and Speech, 38, 189-202.

Yavas, M. (1998). Phonology Development and Disorders. San Diego: Singular Publishing Group, Inc.

Yavas, M. (2003). Speech issues in Bilingualism. MIT Encyclopedia of Communication Disorders. (p.116-119).

Yavas, M., \& Goldstein, B. (in press). "Aspects of bilingual phonology: The case of Spanish-English Bilingual Children," in B. Dodd \& Z. Hua (Eds.) Phonological Development and Disorders: A Cross-Linguistic Perspective. Multilingual Matters. (B. Goldstein, $2^{\text {nd }}$ author). 


\section{Appendix 1}

\section{Matrices of English/Creole Consonants}

\section{English Consonants}

\begin{tabular}{|c|c|c|c|c|c|c|c|}
\hline & Bilabial & Labiodental & Interdental & Alveolar & $\begin{array}{l}\text { Pal. } \\
\text { Alveolar }\end{array}$ & Palatal & Velar \\
\hline Stops & $p \quad b$ & & & $\mathrm{t} \quad \mathrm{d}$ & & & $\begin{array}{ll}\mathrm{k} & \mathrm{g}\end{array}$ \\
\hline Fricatives & & $\mathrm{v}$ & $\bar{\partial}$ & $\begin{array}{ll} & Z\end{array}$ & $\int$ & & $\mathrm{h}$ \\
\hline Affricates & & & & & $\mathrm{t} \int \mathrm{d} 3$ & & \\
\hline Nasals & $\mathrm{m}$ & & & $\mathrm{n}$ & & & $\eta$ \\
\hline Liquid & & & & $\mathrm{l} r$ & & & \\
\hline Glide & $\mathrm{w}$ & & & & $\mathrm{j}$ & & \\
\hline
\end{tabular}

\section{Haitian Creole Consonants}

\begin{tabular}{|c|c|c|c|c|c|c|c|}
\hline & Bilabial & Labiodental & Interdental & Alveolar & $\begin{array}{l}\text { Pal. } \\
\text { Alveolar }\end{array}$ & Palatal & Velar \\
\hline Stops & $\mathrm{p} \quad \mathrm{b}$ & & & $\mathrm{t} d$ & & & k $\quad \mathrm{g}$ \\
\hline Fricatives & & $\mathrm{v}$ & & $\mathrm{s} \quad \mathrm{Z}$ & $\int$ & & $\gamma^{*}$ \\
\hline Affricates & & & & & t $\int \mathrm{d} 3$ & & \\
\hline Nasals & $\mathrm{m}$ & & & $\mathrm{n}$ & & & y \\
\hline Liquid & & & & 1 & & & \\
\hline Glide & $\mathrm{W} \quad \mathrm{y}^{*}$ & & & & $\mathrm{j}$ & & \\
\hline
\end{tabular}

$'=$ Phonemes only present in English

* = Phonemes only present in Haitian Creole

Haitian Creole contains 22 consonantal phonemes

There are no velar fricatives $/ \mathrm{h} /$, no alveolar liquid $/ \mathrm{r} /$ and no interdentals fricatives $/ \theta /, / \mathrm{d} /$

There are two bilabial glides /w/ and / 4 / a voiceless phoneme.

There are 7 vowels in Haitian Creole, which are all voiced: a, e, i, o, u, ว, $\varepsilon$.

Vowels in Haitian Creole can either be oral or nasal. 


\section{Haitian Creole Syllabic Inventory}

\begin{tabular}{|c|c|c|c|}
\hline $\begin{array}{c}\text { Creole } \\
\text { Transcription }\end{array}$ & $\begin{array}{c}\text { French } \\
\text { Translation }\end{array}$ & $\begin{array}{c}\text { English } \\
\text { Translation }\end{array}$ & $\begin{array}{c}\text { Syllable } \\
\text { Shapes }\end{array}$ \\
\hline$/ \mathrm{a} /$ & articles 'le/la' & 'the' & $\varnothing \mathrm{V}$ \\
\hline$/ \mathrm{ak} /$ & avec/acte & 'with' & $\varnothing \mathrm{VC}$ \\
\hline$/ \mathrm{aks} /$ & 'axe' & 'ax' & $\varnothing \mathrm{VCC}$ \\
\hline$/ \mathrm{li} /$ & 'lui/il/elle/le/la/son/sa' & 'he,she,they,his,her' & $\mathrm{CV}$ \\
\hline$/ \mathrm{saf} /$ & 'gourmand' & 'greedy' & $\mathrm{CVC}$ \\
\hline /boks/ & 'boxe' & 'boxing' & $\mathrm{CVCC}$ \\
\hline$/ \mathrm{grã} /$ & 'grand/vieux' & 'big/old' & $\mathrm{CCV}$ \\
\hline /blag/ & 'blague/farce' & 'gossip' & $\mathrm{CCVC}$ \\
\hline
\end{tabular}


Appendix 3

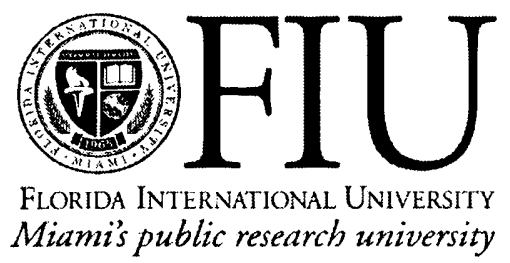

\section{CONSENT TO PARTICIPATE IN A RESEARCH STUDY}

\section{The Phonological Analysis of Bilingual Haitian American Children Living in South Florida}

This form is needed to get your permission and your child's agreement to participate in a research study. The person conducting this study is Carolyn Beaubrun and is a graduate student at FIU in the field of speech language pathology. The reason of this study is to get information about young children's speech. This study will include about 40 children who are Haitian American and speak Haitian Creole and English. If you agree to your child being a part of this study, you will be asked to complete a brief questionnaire. Your child will be given an assessment in English, the Goldman Fristoe Test of Articulation-2 (GFTA-2) then will be asked to name a few pictures using Haitian Creole words. The process should take about 30 minutes. The examiner will show some pictures to the children then will ask them to name the objects in the pictures.

There are no known risks that your child will experience by participating in this study. If your child starts to feel uncomfortable or if they get upset they can take a break. You or your child may request that he/she be taken out of the study at any time without penalty. There is no direct benefit to the child by being a part of this study. But, the information collected will help us to better understand how Haitian children develop their language.

There is no cost to you or your child for participating in the study. Your child will receive one toy or stickers as a thank you for participating in the study.

Your child's data will be identified as an assigned number. All information in this research is private. Information will not be shared with people who are not involved in this study unless required by law. The results will be presented during the defense of this research. You may ask questions about the study at any time.

If you need more information please call me, Carolyn Beaubrun, at (305) 343-9490. If you or your child feel that you were treated badly or need more information about this research study you may call Dr. Bernard Gerstman, the Chairperson of the FIU Institutional Review Board at (305) 348-3115 or (305) 348-2494. 
* If you (the parent/guardian) have had all of your questions answered and you would like your child, to be in the study, please sign your name on the line below.

$$
\text { (Print Child's name) }
$$

Signature of Parent

Date

* I have explained the research process, subject's rights and answered questions asked by the participant. I have offered him/her a copy of this informed consent form.

Signature of Witness

Date 


\section{Appendix 4}

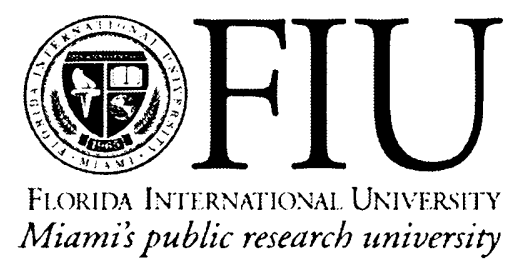

\section{KONSANTI POU PATISIPÉ NAN RÉCHÈCHE}

\section{Analizasyon fonologik timoun Ayisyen Ameriken ki palé dé lang kap viv nan Floride di Sud}

Fom sa a sèvi pou ka di ou dakò pou pitit ou patisipé nan yon réchèche kap fèt. Moun kap fè réchèche la rélé Carolyn Beaubrun. Li sé yon étidien lan FIU kap pran tèz li lan yon pwogram ki konsentré sou kominikasyon ak langaj. Réson ké réchèche sa a ap fèt sé pou nou ka genyen infomasyon sou ki jan timoun dévlopé langaj. Réchèche kap fèt la ap genyen apéprè 40 timoun ki Ayisyen Ameriken ki palé dé lang. Si ou dakò pou pitit ou patisipé nan réchèche kap fèt la, yo pral mandé ou pou répon kèlké kestyon. Yo pral bay pitit ou yon tès an Anglè ki rélé Goldman Fristoe Test of Articulation-2 (GFTA-2). . Tès la ap pren apéprè dé 30 minit. Ekzaminè a pral mandé pitout ou an pou'l bay non foto ki lan tès lan ni an kreyòl ni an Anglè.

Pa gen ékin risk ké moun konnen ki ka fè pitit ou malè lè lap patisipé lan réchèche kap fèt la. Si pitit ou kòmansé vin inkonfòtab ou bin li kòmansé faché li ka pren yon ti souf. $\mathrm{Ni}$ ou ni pitit ou ka decide sispan fè pati réchèche kap fèt la san nou pa gen pénalité. $\mathrm{Pa}$ genyen okin bénéfis dirèk pou pitit la kap patisipé nan réchèche kap fèt la. Men infomasyon ké yo pral kolékté an ap ka édé nou pi byen konpran kijan timoun ki Ayisyen Ameriken ki palé dé lang dévlopé langaj yo.

Pa gen ékin kòb pou ni ou ni pitit ou péyé pou patisipasyon nou nan réchèche kap fèt la. Pitit ou ap récévwa yon jwèt ou bin yon éstikè pou patisipasyon yo nan réchèche kap fèt la nan é pou remèsiman.

Yap itilizé yon nimewo pou timoun lan pou yo ka identifyé'l. Tout infòmasyon nou ap rété privé. Infòmasyon nou pa pral patajé ak pèson ki pa fè pati réchèche sa a sèlman si lalwa mandé. Nap bay résilta yo lè yap défen réchèche la. Ou gen dwa mandé kestyon ninpot ki lè penden réchèche la ap fèt.

Si ou bezwen plis infòmasyon rélém, Carolyn Beaubrun, nan (305) 343-9490. Si ni ou ni pitit ou santi ké yo maltrété nou oubin nou bezwen plis infòmasyon sou réchèche sa a, nou ka rélé Dr. Bernanrd Gertsman, moun ki an chaj lan nan (305) 348-3115 ou bin lan (305) 348-2494. 
* Si ou (paraen/gadyen) pa gen lòt kestyon é ou dakò pou pitit ou, patisipé nan réchèche kap fèt la siyen non ou (ékri non pitit la) sou lijn lan

* Mwen ékspliké réchèche kap fêt la, dwa paren yo ak pitit yo é mwen répon tout kestyon paticipan an. Mwen ofri li yon kopi konsanti sa a. 


\section{HOME LANGUAGE SCREENING QUESTIONNAIRE}

Student Identification Number:

\section{Haitian Creole}

DOB/ Age:

Center:

Respondent's relation to child:

1. What language do you speak at home?

2. What language did your child learn first?

3. Does your child have difficulties talking to people at home? Yes/ No If yes, explain

4. What language does the child use?

a. Language used to speak to the mother?

b. Language used to speak with the father?

c. Language used to speak to brother/sister?

d. Language used to speak to friends?

5. Does the child have difficulties following commands? Yes/No If yes, explain.

6. At what age did the child have his/her first experience with English as a primary language? Explain how:

7. Does the child use one language more than the other? Yes/no If yes, which one?

8. Does the child have difficulties communicating in English? Yes/No Explain how:

9. Does the child watch T.V. in a language other than English? Yes/No If Yes, which one?

10. Does the child listen to the radio in a language other than English? Yes/ No If Yes, which one?

11. How many hours approximately is the child exposed to each language?

English

Creole 


\section{HOME LANGUAGE SCREENING QUESTIONNAIRE Haitian Creole}

Students Identification Number:

DOB/ Age:

Center:

Respondent's relation to child:

1. Ki lang ou palé pi souvan lakay ou?

2. Ki lang pitit ou-a té aprann anpremyé?

3. Eské timoun nan gen pwoblèm pou l pale ak moun nan kay la? Wi/Non Si sé wi éspliké.

4. Ki lang pitit la sevi pou li palé?

e. Lang timoun nan sèvi pou li palé ak manman li?

f. Lang timoun nan sèvi pou li palé ak papa li?

g. Lang timoun nan sèvi pou li palé ak frè/sè li?

h. Lang timoun nan sèvi pou li palé ak zanmi li?

5. Eské timoun nan gen pwoblèm pou li suiv sa yo di-l pou li fè? Wi/Non Si sé wi éspliké.

6. A ki laj timoun té kòmansé fè premyé ékspéryans li ak anglè kòm prensipal lang li? Espliké kijan:

7. Eské timoun nan chwazi yon lang nanplas lòt? Wi/Non Si sé wi kilès?

8. Eské timoun nan gen pwoblèm pou li palé ak moun an anglè? Wi/Non Espliké kouma:

9. Eské timoun nan suiv pwogram télévizyon nan yon lang ki pa anglè? Wi/Non Si sé wi kilès?

10. Eské timoun nan tandé radyo nan yon lang ki pa anglè? Wi/Non Si sé wi kilès?

11. Komben tan pa jou timoun nan éksposé nan chak lang yo?

Anglè

Kréyol 
Appendix 7

STIMULI FORM

Haitian Creole Phonemes

\begin{tabular}{|c|c|c|c|}
\hline & SIWI & SIWW & $\underline{\text { SFWF }}$ \\
\hline $\mathbf{p}$ & $/ \mathrm{pul} / / \mathrm{pisin} /$ & $/$ apo/ /lapĩ $/$ & /kap/ /lãp/ \\
\hline b & /bokit/ /bato/ & /tãbu/ /kabãn/ & $/ \mathrm{tab} / \quad / \mathrm{k}_{\mathrm{ob}} /$ \\
\hline $\mathbf{t}$ & /tab/ /telefon/ & /bato/ /gita/ & /bokit/ /fenct/ \\
\hline d & $/ \mathrm{dife} / \quad / \mathrm{d}_{\supset \mathrm{mi}} /$ & /kado/ /ãndã/ & / $\mathrm{u}_{\mathrm{ad} / \text { /vid/ }}$ \\
\hline $\mathbf{k}$ & /kap/ /kãna/ & /bokit/ /lakol/ & $/ \mathrm{sak} / \quad / \mathrm{k}$ ok/ \\
\hline $\mathbf{g}$ & /gita/ /gode/ & /figi/ /bagaj/ & /bag/ / $\Psi_{\varepsilon g /}$ \\
\hline f & /figi/ /fu $/ \mathrm{Et} /$ & /telefon/ /dife/ & $/ \mathrm{n}_{\varepsilon f} / \quad / \mathrm{b}_{\varepsilon f} /$ \\
\hline $\mathbf{v}$ & /valiz/ /vid/ & /lave/ / Seval/ & /liv//mov/ \\
\hline $\mathbf{S}$ & /savõ/ / /sizo/ & $/$ pisin/ /laset/ & /tas/ /glas/ \\
\hline $\mathbf{Z}$ & /zõy/ /zo ${ }_{\varepsilon j}$ j/ & /sizo/ /rezi/ & $/ \int_{\varepsilon Z / \quad / v a l i z\rfloor}$ \\
\hline $\int$ & $/$ Seval/ $\quad / \int_{\varepsilon z} /$ & $/ \mathrm{fu} \delta \mathrm{Et} / \quad / \mathrm{ta} \mathrm{e} /$ & $/ \mathrm{w}_{0} / / \quad / \mathrm{ni} / /$ \\
\hline 3 & /3on/ /3ip/ & /lazã/ /mãze/ & /g03/ $/ \mathrm{n} \varepsilon 3 /$ \\
\hline$t \int$ & It $_{\int}$ ot $\mathrm{O} /$ & It $\mathrm{t}_{\mathcal{O}} \mathrm{t}_{\mathcal{O}} \mathrm{I}$ & \\
\hline d3 & $/ \mathrm{d} 3 \mathrm{az} /$ & M ad3io/ /bondze/ & \\
\hline m & $/ \mathrm{mõt} / \quad / \mathrm{ma} \int_{\mathrm{in} /}$ & /domi/ /fumi/ & /plim/ \\
\hline $\mathbf{n}$ & $/ \mathrm{n}_{1} / \quad / \mathrm{n}_{\varepsilon \mathrm{f}} /$ & /linet/ / fenct/ & /kabãn/ /3on/ \\
\hline 1 & /linet/ /liv/ & /valiz/ /telefon/ & /bel/ / / bol/ \\
\hline$\eta$ & & & /zõy/ /zeprn/ \\
\hline u $^{*}$ & / $\Psi_{\mathrm{ad} /} / \Psi_{\mathrm{ad} 3 i o} /$ & $/ \mathrm{ma} \mathrm{U}_{\mathrm{e}} / \quad / \mathrm{l} \mathrm{U}$ i/ & \\
\hline $\mathbf{W}$ & $/ w \circ S / \quad / w u /$ & /siwo/ /kawot/ & \\
\hline $\mathbf{j}$ & $/ \mathrm{j} \varepsilon / \quad / \mathrm{jun} /$ & $/$ majo/ $/ \mathrm{d}_{\varepsilon j_{\varepsilon}} /$ & $/ \mathrm{kaj} / \quad$ /zo ${ }_{\varepsilon j} /$ \\
\hline $\mathrm{Y}^{*}$ & $/ 4 i t /{ }^{*}$ & $/ \min 4 \mathrm{i} / \mathrm{k} \mathrm{isis}^{*}$ & \\
\hline
\end{tabular}


Appendix 8

ID \#------

RESPONSE FORM

Date of Test ------

$\mathbf{M} / \mathbf{F}$

Haitian Creole Phonemes Date of Birth

\begin{tabular}{|c|l|l|l|}
\hline & SIWI & SIWW & SFWF \\
\hline $\mathbf{p}$ & & & \\
\hline $\mathbf{b}$ & & & \\
\hline $\mathbf{t}$ & & & \\
\hline $\mathbf{k}$ & & & \\
\hline $\mathbf{g}$ & & & \\
\hline $\mathbf{f}$ & & & \\
\hline $\mathbf{v}$ & & & \\
\hline $\mathbf{s}$ & & & \\
\hline $\mathbf{z}$ & & & \\
\hline $\mathbf{l}$ & & & \\
\hline $\mathbf{3}$ & & & \\
\hline $\mathbf{t}$ & & & \\
\hline $\mathbf{d 3}$ & & & \\
\hline $\mathbf{m}$ & & & \\
\hline $\mathbf{n}$ & & & \\
\hline $\mathbf{l}$ & & & \\
\hline $\mathbf{y}$ & & & \\
\hline $\mathbf{u}^{*}$ & & & \\
\hline
\end{tabular}


Appendix 9
ID \#-----
RESPONSE FORM
Date of Test
$\mathbf{M} / \mathbf{F}$
Haitian Creole Clusters Date of Birth

\begin{tabular}{|c|c|}
\hline dr & /drapo/ \\
\hline br & /brasle/ \\
\hline tr & /trin/ \\
\hline $\mathbf{k r}$ & /krejõ/ \\
\hline gr & /grĩn/ \\
\hline fr & /froma3/ \\
\hline fl & $/ \mathrm{fle} /$ \\
\hline pl & /plat/ \\
\hline bl & /ble/ \\
\hline $\mathrm{dl}^{*}$ & $/ \mathrm{dlo} /$ \\
\hline kl & $/ \mathrm{kle} /$ \\
\hline gl & /glisad/ \\
\hline bw* & /bwe/ \\
\hline pw* & /pwasõ/ \\
\hline$d w^{*}$ & /dwet/ \\
\hline$t w^{*}$ & /twalet/ \\
\hline $\mathbf{z W}^{*}$ & /zwazo/ \\
\hline $\mathbf{p j}^{*}$ & /pje/ \\
\hline
\end{tabular}

* Clusters present only in Haitian Creole 
FLORIDA INTERNATIONAL UNIVERSITY

Miami, Florida

EXTENDED PROGRAM NOTES FOR A RECITAL OF SELECTED VOCAL LITERATURE

A thesis submitted in partial fulfillment of the

requirements for the degree of

MASTER OF MUSIC

by

Kathleen Mary Bell

2011 


\section{ACKNOWLEDGMENTS}

I wish to thank the members of my committee for their patience, support and kindness. My major professor and mentor, Dr. Kathleen Wilson, in particular has been a source of inspiration as a teacher and human being. Her passion, integrity and knowledge of her field are unparalleled. I also would like to thank Dr. Joel Galand for his tremendous patience and deeply insightful comments and corrections on the manuscript. I am deeply humbled by and grateful for the talent and dedication of the professors in the Florida International University Music Department. I have found through the coursework and instruction that I am prepared more fully as a performer and teacher of singing. Finally, I wish to thank my family, friends, parish and students who have encouraged and inspired me throughout this whole process. 


\section{ABSTRACT OF THE THESIS \\ EXTENDED PROGRAM NOTES FOR A RECITAL OF SELECTED VOCAL}

LITERATURE

by

Kathleen Mary Bell

Florida International University, 2011

Miami, Florida

Professor Kathleen Wilson, Major Professor

The purpose of these extended program notes is to provide information that will assist the listening audience in comprehending the historical and biographical significance of the each vocal selection. A brief analysis of each selection, a historical interpretation of the work, a translation of the texts and a $\mathrm{CD}$ of the recital are included. The contents of the recital comprise of several selections from the soprano repertoire: The Georg Phillip Telemann cantata Lauter Wonne, lauter Freude; the Wolfgang Amadeus Mozart Laudate Dominum from the Vesperae solemnes de confessore; the Joaquín Nin y Castellano Diez Villancicos de Noël; Gabriel Fauré's art songs Dans le ruines d'une abbay, Les Berceaux, and Au bord e l'eau; Sergei Rachmaninov's three songs Oni otvechali, Zdes Khorosho, and Vocalise; and Libby Larsen's Cowboy Songs. 


\section{TABLE OF CONTENTS}

CHAPTER

PAGE

INTRODUCTION. 1

I. Georg Philip Telemann: Lauter Wonne, lauter Fruede.......................2

II. Wolfgang Amadeus Mozart: Laudate Dominum from Vespere Solennes.....10 de Confessore

III. Joaquin Nín y Castellanos: Diez Villancicos de Noël........................12

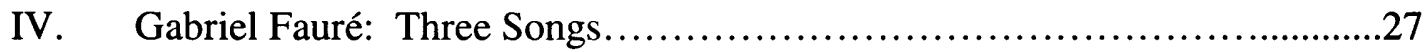

V. Sergei Rachmaninov: Three Songs.....................................33

VII. Libby Larsen: Cowboy Songs........................................39

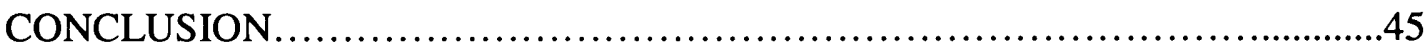

LIST OF REFERENCES ...........................................................

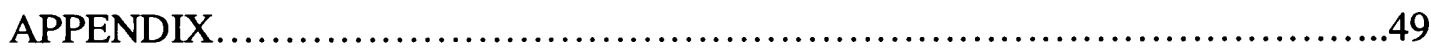




\section{LIST OF FIGURES}

FIGURE

PAGE

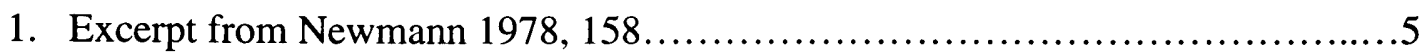

2. Lauter Wonne, lauter Freude: flute and voice part, mm. 10-15.................6

3. Lauter Wonne, lauter Freude: flute part, mm. 33-35.........................

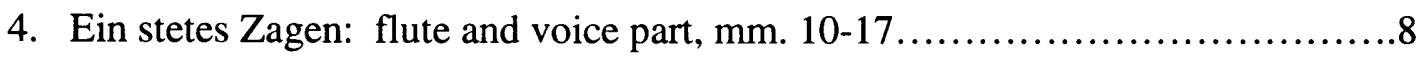

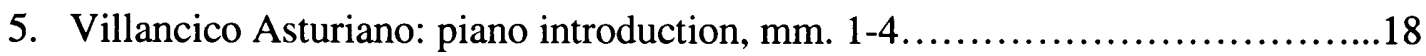

6. Villancico Gallego: piano introduction, mm. 1-8............................19

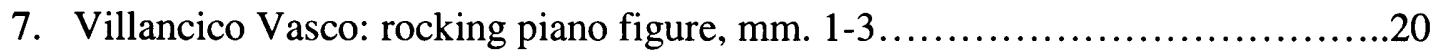

8. Villancico Castellano: piano introduction, $\mathrm{mm} .1-11 \ldots \ldots \ldots \ldots \ldots \ldots \ldots \ldots . \ldots 21$

9. Villancico de Cordoba: piano introduction, mm.1-9.......................22

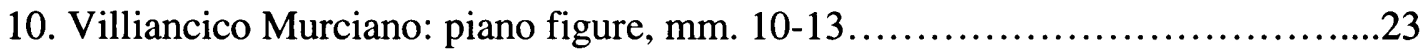

11. Jesús de Nazareth: Ay! Vocal motive: mm. 1-10...........................25

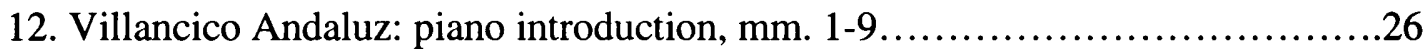

13. Les Berceaux: piano introduction with rocking rhythm, $\mathrm{mm} .1-2 \ldots \ldots \ldots \ldots \ldots . . .31$

14. Oni otvechali: vocal part with the last answer, mm. $18-24 \ldots \ldots \ldots \ldots \ldots \ldots \ldots . \ldots 36$

15. Vocalise: voice and piano counterpoint, $\mathrm{mm} .33-35 \ldots \ldots \ldots \ldots \ldots \ldots \ldots \ldots \ldots \ldots$

16. Bucking Bronco: example of text painting, $\mathrm{mm} .11-12 \ldots \ldots \ldots \ldots \ldots \ldots \ldots \ldots . \ldots \ldots 1$

17. Bucking Bronco: piano rhythmic figure, $17-18 \ldots \ldots \ldots \ldots \ldots \ldots \ldots \ldots \ldots \ldots \ldots 42$

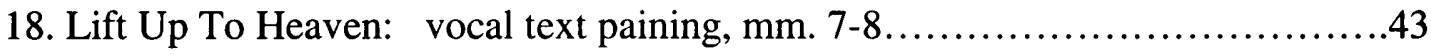

19. Billy the Kid: Shortnin' Bread quotation in piano accompaniment: mm. 1-3 ...43

20. Billy the Kid: text painting of the word rage with ossia, mm. 10-11 ...........44

21. Billy the Kid: Return of Shortnin' Bread quotation, mm. 17-21 ...............45 


\section{INTRODUCTION}

This voice recital was given in partial fulfillment of the requirements for the Master of Music degree in Vocal Performance. The recital was performed on Tuesday, March 29, 2011 in the Wertheim Performing Arts Center Instrumental Hall at 8:00 PM. A brief biography of each composer, analysis, interpretation and translations of each selection as well as an accompanying $\mathrm{CD}$ are included. 


\section{Georg Philipp Telemann: Lauter Wonne, lauter Freude}

Telemann originally scored his cantata Lauter Wonne, lauter Freude for high voice, alto recorder and basso continuo. In this recital the cantata will be performed by high voice, transverse flute and piano. The extremely prolific composer published it at the height of his career as part of a cycle of seventy-two solo cantatas titled Harmonischer Gottesdienst (Hamburg, 1725-26). The author, Matthäus Arnold Wilkens (1704-1759), based the text of Lauter Wonne on the fourth chapter of the Epistle to the Philippians, verses 4-9 (Whybrow 2009, 1). It was written to be performed on the fourth Sunday of Advent.

Georg Phillip Telemann, born in Magdelburg, Germany on March 14, 1681 was widely regarded as “Germany's leading composer in the early and middle $18^{\text {th }}$ Century...an important link between the late Baroque and the new Classical style" (Ruhnke 1985, 281). Although there is no definitive count of the number of works this self-taught musician composed, it is widely accepted that he composed some 1,500 sacred cantatas. He composed at least 3,000 works (half of them lost) in every genre and style of his day. Unconstrained by a formal musical education, he learned by studying the scores of great masters.

Telemann was instrumental in transforming German musical life. He had served in several important musical posts when, at the age of forty, he won his most significant position. In July, 1721, the city of Hamburg offered him the prestigious post of Kantor of the Johanneum, a post which also involved the musical directorship of the five main churches in the city. His duties included composing two cantatas a week, producing a new Passion annually, as well as providing masses and incidental music for numerous 
other feast days and liturgies. Although his post was limited to the composition of sacred music, the industrious Telemann also became involved with the Hamburg Opera. This was remarkable because “ $[u]$ ntil the $18^{\text {th }}$ century a composer's output was largely dictated by the nature of the post he held, and the various spheres of musical activity were strictly defined. Telemann refused to be fettered, as a composer, by the chains of his official duties; and he broke down the barriers between sacred and secular music" (Ruhnke 1985, 295). The Hamburg city fathers tried to force him to refuse the position of director of the Hamburg Opera. In response, Telemann applied and was awarded another position in Leipzig. In the end, the city fathers refused to release him from his contract. The ending result was an increase in salary and that they cease their objections to his participation with the Hamburg Opera.

Telemann organized public concerts of both his sacred and secular works. He was also one of the first musicians who published his own musical compositions, engraving them himself. Telemann was a very wealthy and highly respected man in his day. Publishing music and producing public concerts was prompted more by a desire to help his fellow man enjoy good secular and sacred music than for monetary considerations. He paved the way for musicians to have artistic control over the publication and performance of their own music, which was unprecedented in eighteenth century Germany. Additionally, he was very influential on the young musicians surrounding him. "Even in his youth... he inspired and stimulated the most gifted music lovers among his fellow students to become professional musicians" (Ruhnke 1985, 297).

Telemann's cantatas were extremely popular in his day because they were practical and musically fashionable, tuneful and relatively easy to play. Each cantata in the 
Harmonischer Gottesdienst was originally published individually so that it might be performed in other churches as well as private homes. All of the cantatas are scored for solo voice, solo obbligato instrument and basso continuo. During the Baroque period obbligato referred to an essential instrumental part that was fully written out. The basso continuo consisted of a notated bass line entrusted to a low instrument (e.g., the viola da gamba), supplemented with a keyboard part that fleshed out this bass line into a full chordal accompaniment. This accompaniment was more-or-less partially improvised; sometimes, the composer provided figures to indicate how he wanted his bass line realized and sometimes he merely provided an unfigured bass. This sparse instrumentation allowed these cantatas to be used for either private devotions or as the second cantata after the sermon, when the majority of paid musicians would have already left for another performance. These cantatas, all of them based on the Epistle reading for that Sunday. consist of two da capo arias with an intervening recitative. A da capo aria was one that was comprised of three sections: (A); a central section (B), often contrasting in mode and emotional affect; and a repeat of the A section. The texts are poetic paraphrases of Scripture, rather than exact quotations.

"In the forward of his Harmonischer Gottesdienst Telemann elaborates on various aspects of performance practice. He goes into great detail about how to treat the voice in the recitatives and demonstrates by many examples in the music that the notation often deviates considerably from the desired performance. This concerns in particular the last two notes before rests, but transition notes [i.e., passing tones] and suspensions can nevertheless be inserted in other places" (Whybrow, 2009). 


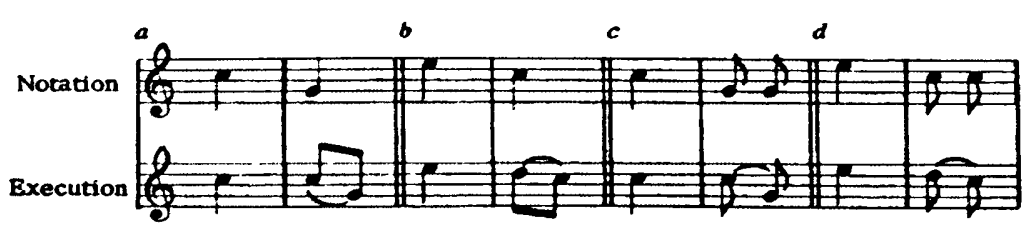

Ex. 16.52. Telemann's Recitative Formulas

Figure 1 Excerpt from Newmann 1978, 158

In the Lutheran liturgy, Philippians 4:4-9, the epistle on which the cantata's text is based, is read on the fourth Sunday of Advent.

Rejoice in the Lord always. I shall say it again: rejoice! Your kindness should be known to all. The Lord is near. Have no anxiety at all, but in everything, by prayer and petition, with thanksgiving, make your requests known to God. Then the peace of God that surpasses all understanding will guard your hearts and minds in Christ Jesus. Finally, brothers, whatever is true, whatever is honorable, whatever is just, whatever is pure, whatever is lovely, whatever is gracious, if here is any excellence and if there is anything worthy of praise, think about these things. Keep on doing what you have learned and received and heard and seen in me. Then the God of peace will be with you (New American Standard Bible).

- The text of "Lauter Wonne, lauter Freude spielt in meiner regen Brust" is translated as "Sheer (or pure) bliss, sheer (or pure) joy, plays in my stirred breast" depicts the uplifting character of Advent, the period of waiting for the coming of the Christ child. The Aria is marked vivace and is in $6 / 8$ time, in the style of a gigue. During the A section of this da capo form, set in the bright key of $\mathrm{G}$ major, Telemann uses repeated $32^{\text {nd }}$ note embellishments sequentially in both the voice and obbligato part every time the singer sings "regen" evoking the image of a "stirred" heart. 

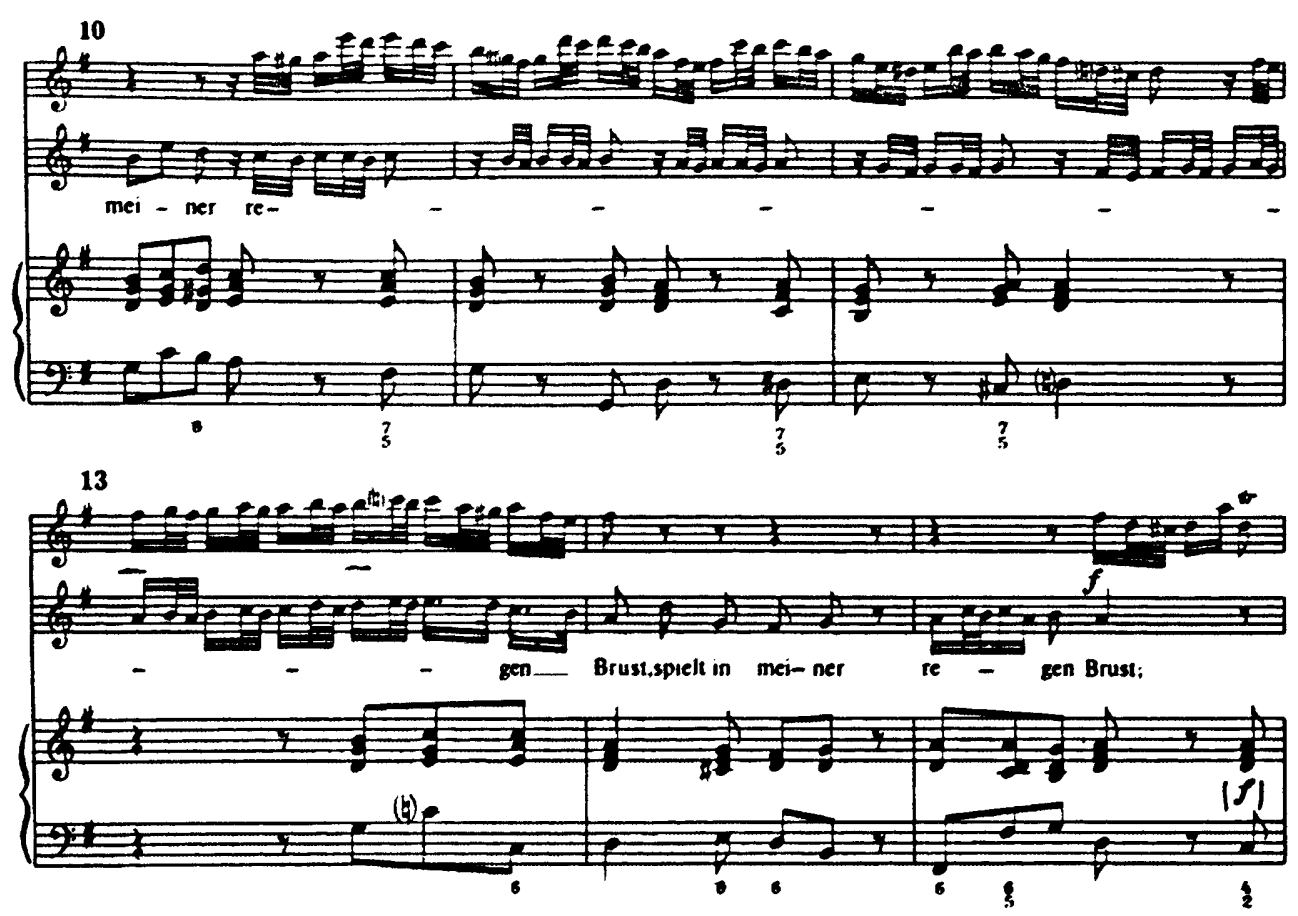

Figure 2 Lauter Wonne, lauter Freude: flute and voice part, mm. 10-15.

In the B section, which is written in the style of a siciliano or pastorale, the text exhorts the listener to find desire only in God and not worldly vanities. The vocal line is simply set while the obbligato stirs with florid thirty-second note melismatic passages from the A section. These passages are juxtaposed to what is expressed in the text as a "desire for God" and the "flaming breast." The only text that is repeated is that of Gott allein ist seine Lust (God alone is their desire). It is sung three times, a Judeo-Christian literary tradition to emphasize the superlative nature of living a life where God alone is their source of desire. 


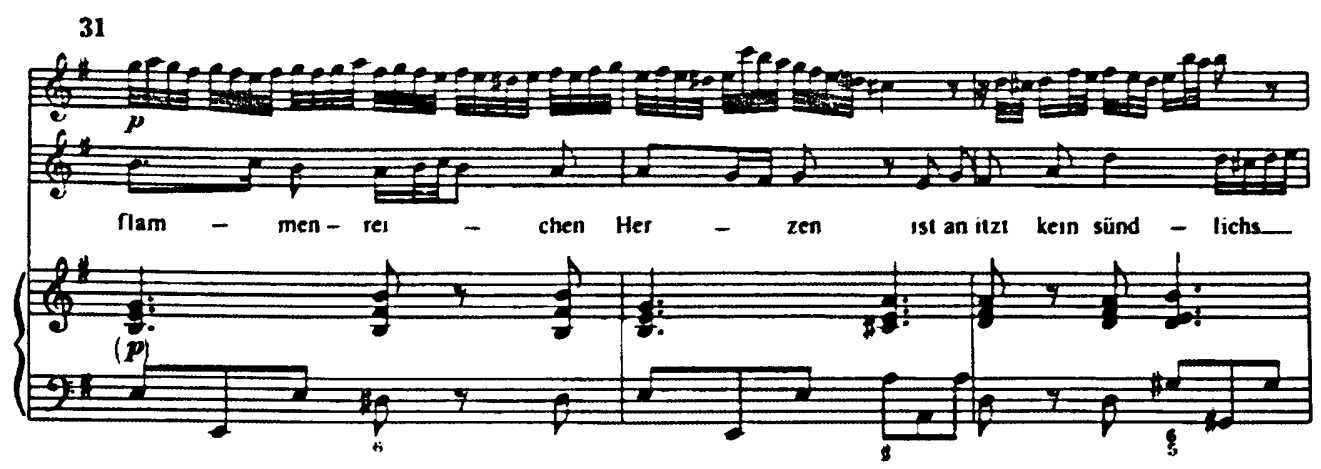

Figure 3 Lauter Wonne, lauter Freude: flute part, mm. 33-35.

The recitative casts a shadow on the joyful anticipation of the first movement; it describes those who refuse to relinquish the "Scherzen einer eitlen Gluht" ("pleasures of idle fancy") alluded to in the Aria. The recitative text cites several pitfalls: chasing after pleasure, money and possessions, high honor, revenge and further unspecified earthly things. The recitative concludes with an allusion to Ecclesiastes: all things pass away and only those who find pleasure in God will experience true joy and salvation. The tessitura of the recitative is very high and rests in the upper passaggio of $\mathrm{e}^{2}$ to $\mathrm{g}^{2}$ and the tonality centers around the dominant.

The second aria begins in G minor, depicting the text which talks of "constant trembling, an eternal gnawing" ("ein stetes Zagen, ein ewigs Nagen") that awaits those who laugh about the Christian faith. The tempo is in the style of a slow sarabande, with its $3 / 4$ time signature and emphasis on beat two. With the word beschließet, the tonality switches to $B^{b}$ major and the tempo increases, suggesting a stylistic shift from a sarabande to a courante, which is a lively dance in three quarter time characterized stepwise passagio. Telemann depicts the word lachen (laughing) with four repeated staccato eighth notes on $\mathrm{d}^{2}$, followed by a four sixteenth note turn that oscillates between 
major and minor tonic chords. After the word, Welt (world), the stately sarabande tempo returns, this time in $B^{b}$ major, but quickly move to $G$ minor via a series of secondary dominants all leading to the laughter that this time is represented by the same tempo change from sarabande to courante and by repeated octave leaps $\left(\mathrm{g}^{3}\right.$ to $\left.\mathrm{g}^{2}\right)$ in the vocal part. The flute obligato now takes up the motive of four sixteenth-note turns.
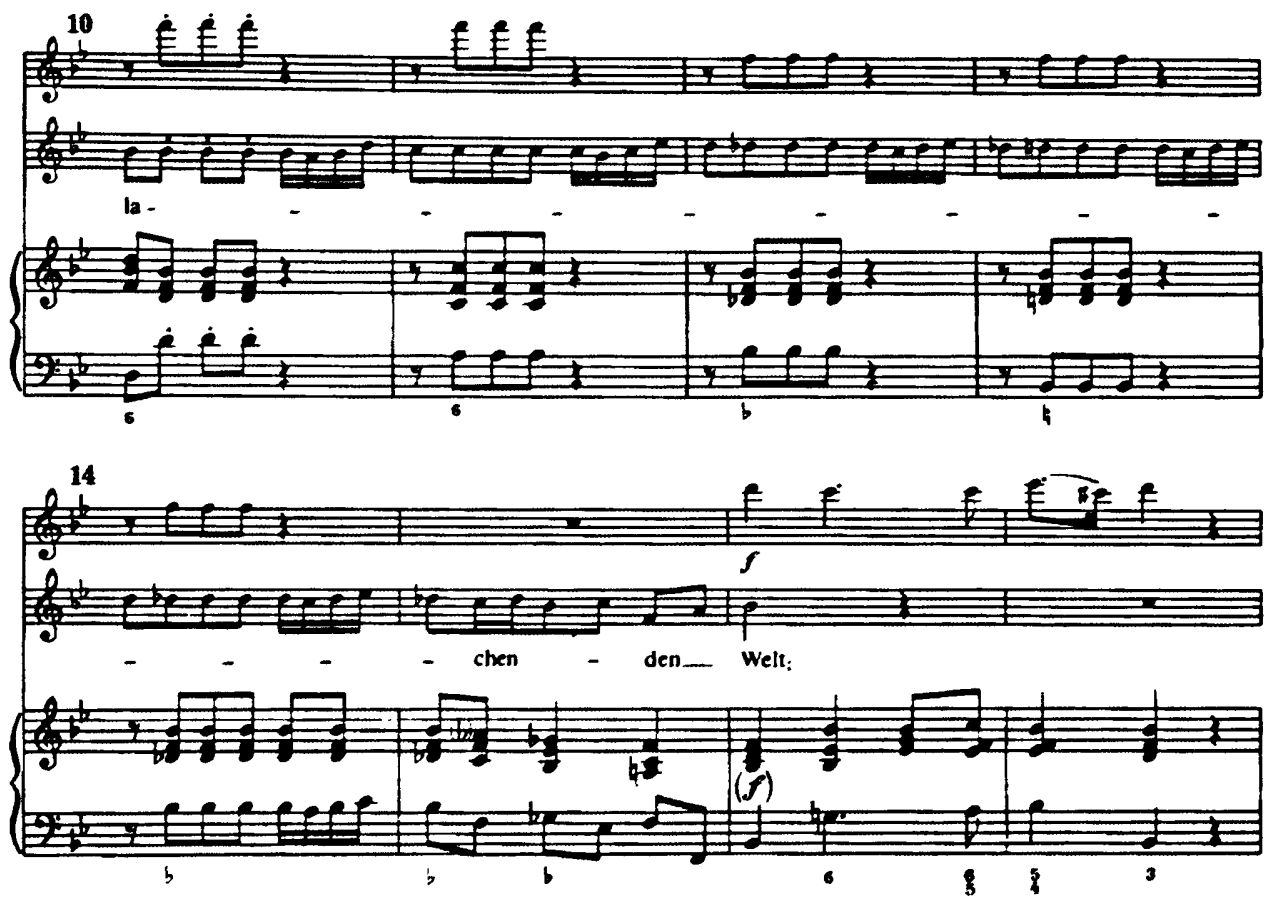

Figure 4 Ein stetes Zagen: flute and voice part, mm.10-17.

The B section is in G major and alludes topically to the Italian corriente, since it is in a somewhat faster $3 / 4$ time. Here the text speaks of the delights and everlasting pleasure of those who seek joy in God. The text setting is straight forward with ewig (forever) being repeated several times to emphasize that this joy in God is everlasting.

Lauter Wonne, Lauter Freude, as with all the cantatas from the Harmonischer Gottesdienst, demonstrates the aesthetics of style of the late German Baroque period. According to the two leading music theorists of his day, Johann Scheibe (1708-1776) and 
Johann Mattheson (1681-1764), "church music should aim to arouse the emotions in a specific way and to interpret the finer points of the text dramatically. To achieve this, the most appropriate style was that of the theatre, for even in church we are only human beings, susceptible to human representations... sacred music demanded an elevated style the more vividly to bring out the imager and 'affect' of the text" (Ruhnke 1985, 300). Telemann was a master of depicting the text, treating the words "stirred" and "laughter" dramatically and treating the concepts of joy in God with soaring lines. An analysis of Telemann's music provides evidence that its quality is just as impressive as its quantity. 
II. Wolfgang Amadeus Mozart: Laudate Dominum from Vesperae solemnes de confessore

Laudate Dominum is the fifth section of the Vesperae solemnes de confessore, K.339 composed by Wolfgang Amadeus Mozart in 1780 for the Salzburg Cathedral. The text is the traditional Latin text based on Psalm 117from the Vulgate, which is the fourth century, authorized Roman Catholic Translation of the Bible. Vespers, which is celebrated at sunset, is the seventh canonical office, or time of prayer; its principle elements are drawn from the Psalms, the Magnificat canticle and their antiphons. Among the many criteria for a Solemn Vespers, all Psalms, antiphons and canticles must be sung during the service This indicates that K339 was most likely composed for a Festum Pallii or an important feast day, however, there is no record of a performance at the Cathedral.

Although Mozart had been granted a coveted church position, 1780 was a time of personal unrest for him fueled by his mother's death in 1778 , the unrequited love of Aloysia Weber and the restrictions that Archbishop Hieronymous von Colloredo of Salzburg imposed on his music. Mozart considered these restrictions demeaning, although in his insistence that the music needed to be concise, brief, and subservient to the liturgy, Colloredo was merely enacting in Salzburg the more modern, enlightened approach to liturgy that the Josephinian reforms were effecting in Vienna. More specifically, liturgical music needed to be earnest and church-like, with stricter contrapuntal procedures in order to aspire to "higher goals" (Albert 2007, 566). Mozart was a musical prodigy and able to adapt to any style. He viewed composing almost like 
breathing, being in a state of constant inspiration. "Artistic creativity constituted the true meaning of Mozart's life and, as a result, was also his destiny" (Albert 2007, 566).

As part of his duties to the Court of Salzburg, Mozart wrote two settings of the Vespers psalms. Laudate Dominum derives from the second and better known setting. The Vesperae Solemnes ranks among Mozart's most enduring church compositions. He was particularly proud of this work and asked that his father send it to Gottfried Van Sweten, an Austrian patron of the arts. In accordance with the Archbishop's requirements, Mozart sets the long texts simply with little verbal repetition. The music alternates between solo sections and four- part homophony. In addition, the key scheme is limited to tonic ( $\mathrm{F}$ major), dominant (C Major), subdominant $\left(\mathrm{B}^{\mathrm{b}}\right.$ major).

The meter of Laudate Dominum is in 6/8 time and has markedly less pronounced virtuosic features than his other vocal works. The graceful floating vocal line seems to emerge out of the piano melody. The vocal range $\left(d^{1}\right.$ to $\left.f^{2}\right)$ and the tessitura is modest. The Laudate Dominum was originally scored for Soprano solo, SATB choir, and orchestra. For this recital it will be performed with soprano voice and piano. The ending “Amen" displays the soprano's soaring legato line, albeit with understated elegance. In Laudate Dominim the words of the psalmist, "Praise the LORD, all you nations! Give glory, all you peoples! The LORD'S love for us is strong; the LORD is faithful forever. Hallelujah!" (New American Standard Bible) are realized. 


\section{Joaquín Nin y Castellanos: Diez Villancicos de Noël}

A villancico is a variety of Spanish secular pastoral or love poetry from the second half of the $15^{\text {th }}$ century set to music as a popular song. In the late $16^{\text {th }}$ century the sacred villancico began to dominate. These works were frequently performed in services and processions at Christmas, Corpus Christi and other feast days. This was the main way of explaining the Gospel and the stories of the main feasts, since the majority of the populace was illiterate. Although in modern times the villancico has come to mean Christmas carol, the more accurate title would be Villancico de Noël. The main themes of the villancico include 1) the person of the Christ Child, 2) the Nativity at Bethlehem, 3) the divinity of the child, and 4) the purpose of his birth: redemption. There is often a reference to the two animals: the "mula y buey" (mule and ox) and a cave or stable being referred to as a "portal" or archway.

Traditionally there is a thematic insistence of the "cold," because of the traditional celebration of Christmas on the $25^{\text {th }}$ of December in the villancicos. The villancicos also depict the poverty and hardship of Bethlehem, which was also common in Spain at that time. There is often someone asking for shelter from the cold. The journey to Bethlehem is considered allegorically as the progress of the sinner to God, only with the help of the Christ Child. The human nature of Christ is often referred to as a garment. The main purpose of the villancico seems to be to connect the nativity of Christ with that of His Passion. His death is the very purpose of his birth. Another common theme is one of praising Mary due to her position as Mother of God, for Mary's name is the symbol of all happiness just as she is its source. 
Diez Villancicos de Noël are based on popular folk themes from ten different regions of Spain. Folk music is music that seems to be the natural and instinctive expression of the people, one that is not influenced by scholastic elaboration. The music is handed down orally creating a collective tune because it undergoes changes with each retelling. Since each selection hails from a different region of Spain, Nin takes us on a virtual musical tour of the country.

Before commencing a musical tour of the regions of Spain, it is important to discuss the composer, piano virtuoso and musicologist Joaquín Nin y Castellanos. Although Nin was born in Cuba, he is considered to be the first Spanish nationalist composer for several reasons: Nin was born in Havana while it was still a Spanish colony, he spent most of his life in Europe, his education was Spanish and he composed Spanish folk music, not Cuban folk music (Marco 1993, 62). In 1902, Nin moved to Paris to study piano and composition with Mozkowski at the Schola Cantorum. He made his professional piano debut in Paris in 1904 presenting the works of Charbonnieres, Couperin and Rameau. Nin was a passionate proponent of Baroque piano composers, most especially Father Antonio Soler, who has been considered the most gifted of Spanish eighteenth century composers (Kimball, p.507). Since Nin was the main proponent of the music of Father Soler, who had studied with Domenico Scarlatti, Nin, like many modern Spanish composers was also greatly influenced by the music of Domenico Scarlatti. Nin arranged two volumes titled Classiques Espagnols du Piano that consisted of piano pieces by Soler and his contemporaries, who were mostly clerics and Catalans. Nin helped bring about the latter day renaissance of Spanish music through his skillful and sensitive 
arrangements of songs and keyboard pieces of the past (Marco 1993, 62). He became a piano professor in 1906. In 1909, the same year that he published his first book Pro Arte that dealt with the aesthetics of music, he returned to Cuba in what would be a failed attempt to create a national conservatory.

Nin was a leading member of the elite group of Spanish musicians living in Paris which included Albéniz, Granados, de Falla, Turina and the pianist Ricardo Viñes. Paris, at the beginning of the twentieth century, was the center of intense musical and artistic activity. A great majority of $20^{\text {th }}$ Century Spanish composers gathered there to be inspired, compose and eventually be published for the first time. As part of his "mission," he promoted the idea that "Art" required a renunciation of the self. He was more concerned with serving the music than the audience. Nin believed that the two main musical ills of his time were commercialism and virtuosity. Nin believed that the art of interpretation should be a sort of priesthood. His second publication Idées et Commentaires was devoted to fighting egoism in art.

Nin's knowledge and enthusiasm for the folksongs of his adopted mother country, Spain, knew no bounds. His arrangements are characterized by melodic charm, rhythmic vitality and folksy warmth. In 1923, along with Maria Barrientos, he premiered several songs from the Spanish repertoire of the $18^{\text {th }}$ century, some of his arrangements for several folk songs and five old Spanish tonadillas from the $18^{\text {th }}$ century. Adolfo Salazar wrote of his Canciones populares españolas, "Joaquín Nin had won an enviable reputation as a specialist of the old classics, of the oldest, most forgotten classics" (Marco 2993, 60). Since Nin was a virtuoso pianist, his folksong arrangements reflect his very 
individual pianism and are carefully annotated. He considered the villancicos to be stylizations, not transcriptions or even harmonizations, but melodies for voice and piano that utilized folk themes. He indicates that prudence is required and that "the instrumental accompaniment of the Spanish folk song has its requirements and we could say, its technical traditions, not at all scholastic, but with an evident charm" (Cockburn 1992, 116).

In Paris Nin's musical and intellectual life thrived, but his familial life suffered. Joaquín had married for money. His wife Rosa was from an aristocratic, wealthy Danish family in Cuba. At first the marriage seemed to work as he was extremely narcissistic and Rosa was dedicated to his career. However, Nin family life soon consisted of constant financial troubles, a general disdain for his young children, frequent beatings and inappropriate pictures. The only physical and emotional intimacy with his famous literary daughter, Anaïs Nin, took place under ritual punishment or pornographic photo sessions. In 1912, Nin, who has been described as a philandering, abusive and immature man who made no secret of his sexual adventures, sent his wife and children to live with his parents in Barcelona and abandoned his family forever. In 1914, Rosa set sail with her children for New York to start a new life.

Once his family was out of the picture Nin lived like a prince in the elegant suburb of St. Cloud. He kept a salon that vied with that of Albéniz as a milieu where the best of Parisian musical society could be met. Nin was a colorful and controversial character, whose aristocratic bearing won him a place in the highest levels of society. He had the artist's nature, a love of music and aesthetics. He was a perfectionist, but did not believe 
perfection was actually attainable. He strove for mastery and control over his life, but he was aware of its destructiveness and how close we all are to death at any moment. This mindset gave him a keen sense of the absurd. A self-proclaimed realist, Nin believed in power and in lust, espousing that these so called virtues elevated one to a spiritual plane and lifted us from the physical.

Diez Villancicos de Noël was composed by Joaquín Nin y Castellanos from 1932 to 1933. There is one very interesting aspect of his life that is not found in your usual biography: his relationship with his daughter, diarist, actress and author Anaïs Nin. The composer had had virtually no relationship with his first family for the better part of twenty years. In 1932, under the advice of her therapist Anaiis began to correspond with her father. She was obsessed with the abandonment and desperately wanted to connect with her father. Nin searched for a "soul love" in his daughter, not merely a physical love. He thought this soul love would replace institutional religion, give us power and in the end liberate us. With her therapist's approval, Anaïs planned to seduce her father and then abandon him just as he had abandoned her as a little girl. In 1933, father and daughter were lovers for 9 days and then she did in fact abandon him. It was during these two personally eventful years that he composed these highly religious folk songs. The author has indicated the year of composition for each one, for perhaps a correlation can be drawn between their composition, the consummation of this relationship and its ultimate demise.

It is with this beneath our consciousness that our tour of Spain through the artistic vision of Joaquín Nin y Castellanos begins. Spain has been called by Ortega y Gasset, the 
Spanish Liberal philosopher, not a nation, but a series of watertight compartments, since most are divided by either rivers or mountain ranges. Each region of Spain retains a completely individualistic concept of itself with its own traditional dances, folk music and in many cases language. Many villagers only speak the language of their region until they begin formal scholastic studies where Castillian is taught. There seems to be many explanations for this regional isolationism according to Gilbert Chase (Chase 1959, 15). He cites the natural barriers of rivers and mountains that divide the country. He also believes the Spaniard to be a stubborn individualist, the strongest being that of the Catalán, the land of Nin's father. Spanish folk music is amongst the richest in the world partly due to the many cultures that have mingled in the Iberian peninsula, most importantly the Celts, Jews and Arabs.

Nin begins with Asturias in the northwest portion of Spain closest to France. This was the first Christian kingdom on the Iberian Peninsula and since it rains has a lush green landscape. When describing the folk music of Northern Spain which includes Asturias, Galicia, the Basque provinces and Catalonia, Nin states that "things are different, rhythm grows calm, widens up, ceases to shake and has a certain majesty, then gives way to the song in its noblest and purest meaning" (Cockburn 1992, 117). This villancico was composed in 1932 and contains a stately walking rhythm of the piano introduction. The first line of the carol states that nothing can compare with a walk at one to see the Child in the cradle. The poetry is representative of the standard villancico with its reference to the child in the cradle and the remembrance of the meaning of his 
birth, the shedding of his blood. Could Nin have placed this one first because he felt he was in need of redemption?

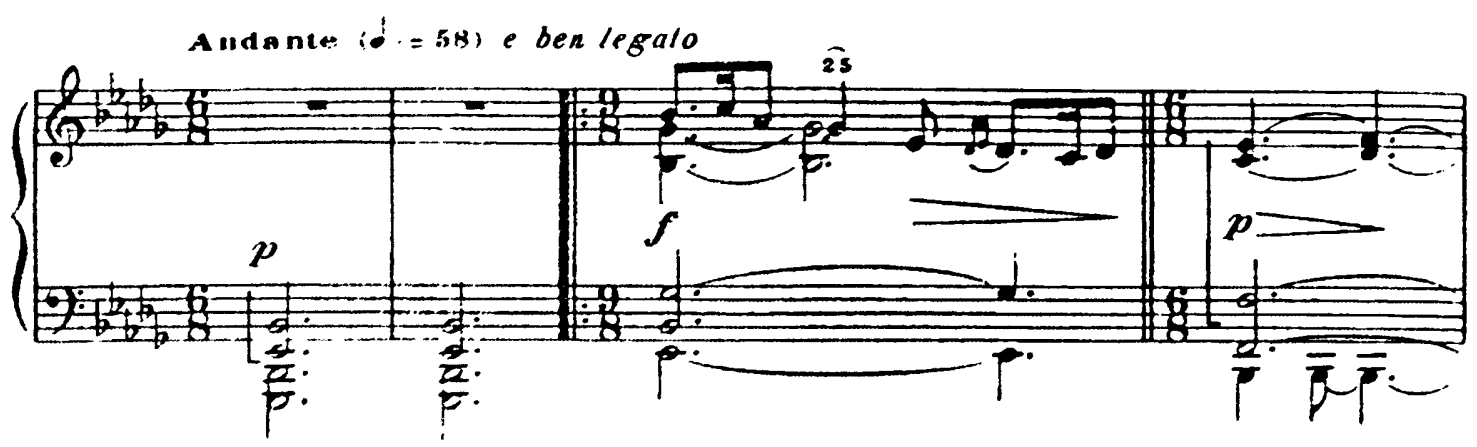

Figure 5 Villancico Asturiano: piano introduction, mm. 1-4.

The second villancico, also composed in 1932 and being one of two of his villancicos not taken from a popular theme, takes us to Spain's extreme Northwestern corner, to the land of Galicia. Galicia is most famous for its pilgrimage to the Shrine of Santiago de Compostela. St. James the elder is the patron saint of Spain, the first supposedly to preach the Gospel in Spain. This carol is also composed in 1932. The language of the people of this region and this villancico is Gallego. Gallego and Portuguese in medieval times were a single language. Although this carol retains a stately nature, the rhythm is a precursor to flamenco, which one can hear in the first lines of the voice part in $6 / 8$ time and the dotted eighth note followed by a sixteenth note and then four eighth notes pattern. This measure is then followed by a $3 / 4$ bar with equal quarter notes. This villancico also has another typical feature in that there are two verses with repeated refrain. 

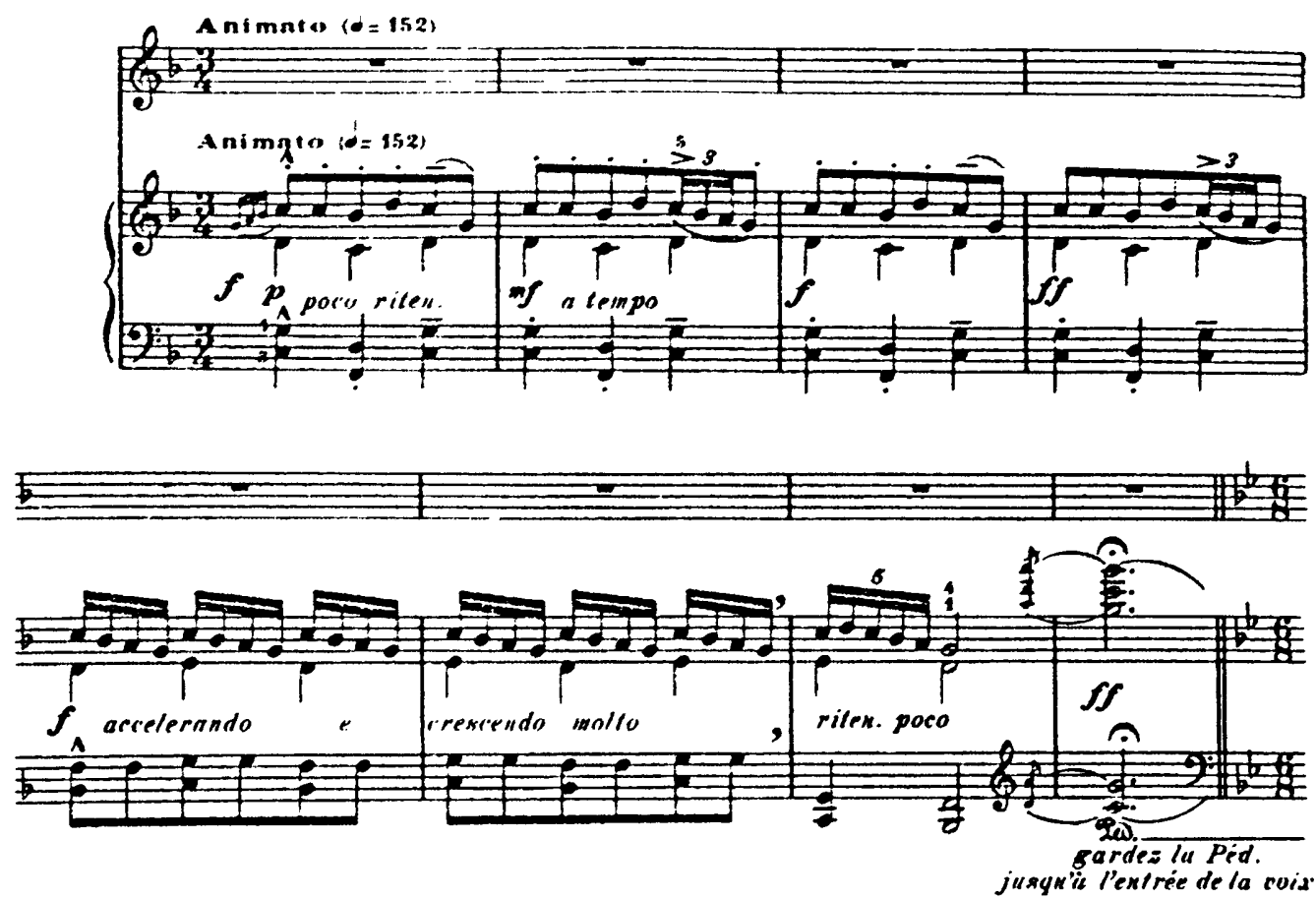

Figure 6 Villancico Gallego: piano introduction, mm. 1-8.

The third villancico, also composed in 1932, utilizes a popular tune from the Basque Region, in the north central part of Spain. The carol is sung in Basque or Euskera, which is considered a genetic language isolate, one that has not been demonstrated to be descended from an ancestor common to another language. Like the Basque people whose foremost value is that of the family, this villancico is a lullaby and the subject matter is not of the Christ child, but how we will celebrate as a family Christmas Eve. The accompaniment represents the rocking of the cradle with its eighth note, quarter note, eighth note quarter note repeated pattern in 6/8/time. 


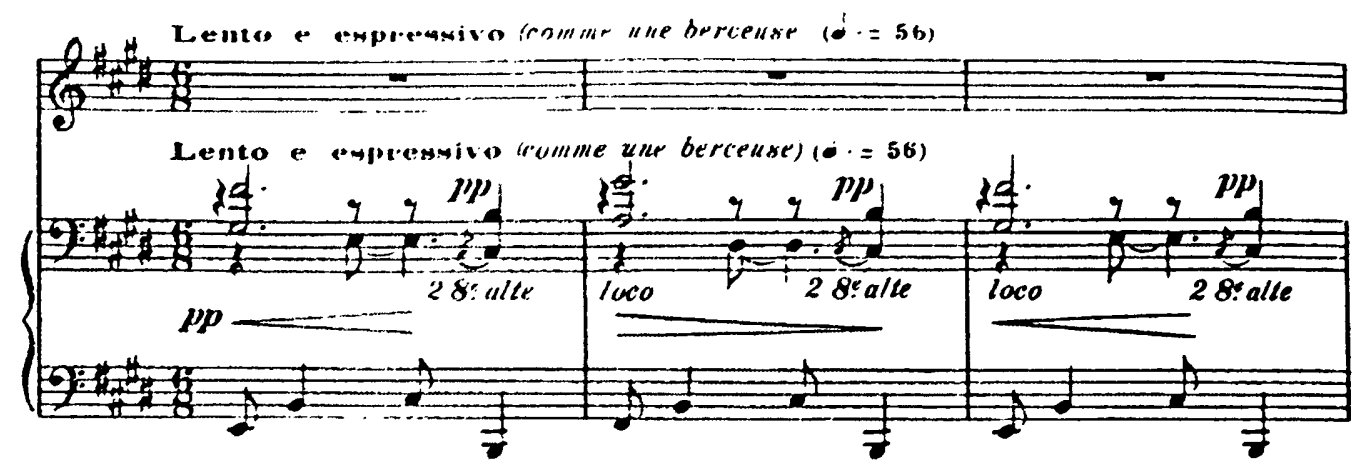

Figure 7 Villancico Vasco: rocking piano figure, mm. 1-3.

The fourth villancico, composed in 1933 to a popular theme, is named after the central part of Spain. This is by far the largest region in that it consists of Castilla y León, Madrid, Castile la Mancha and Extramadura. It is here that Spain's nationalist movement was born. It is here that one hears the influence of the Moors with the "Ay," which is pronounced [a i], accenting and holding out the second vowel, [i]. Also present is the dance rhythm, which celebrates that from humble beginnings paradise has come. 

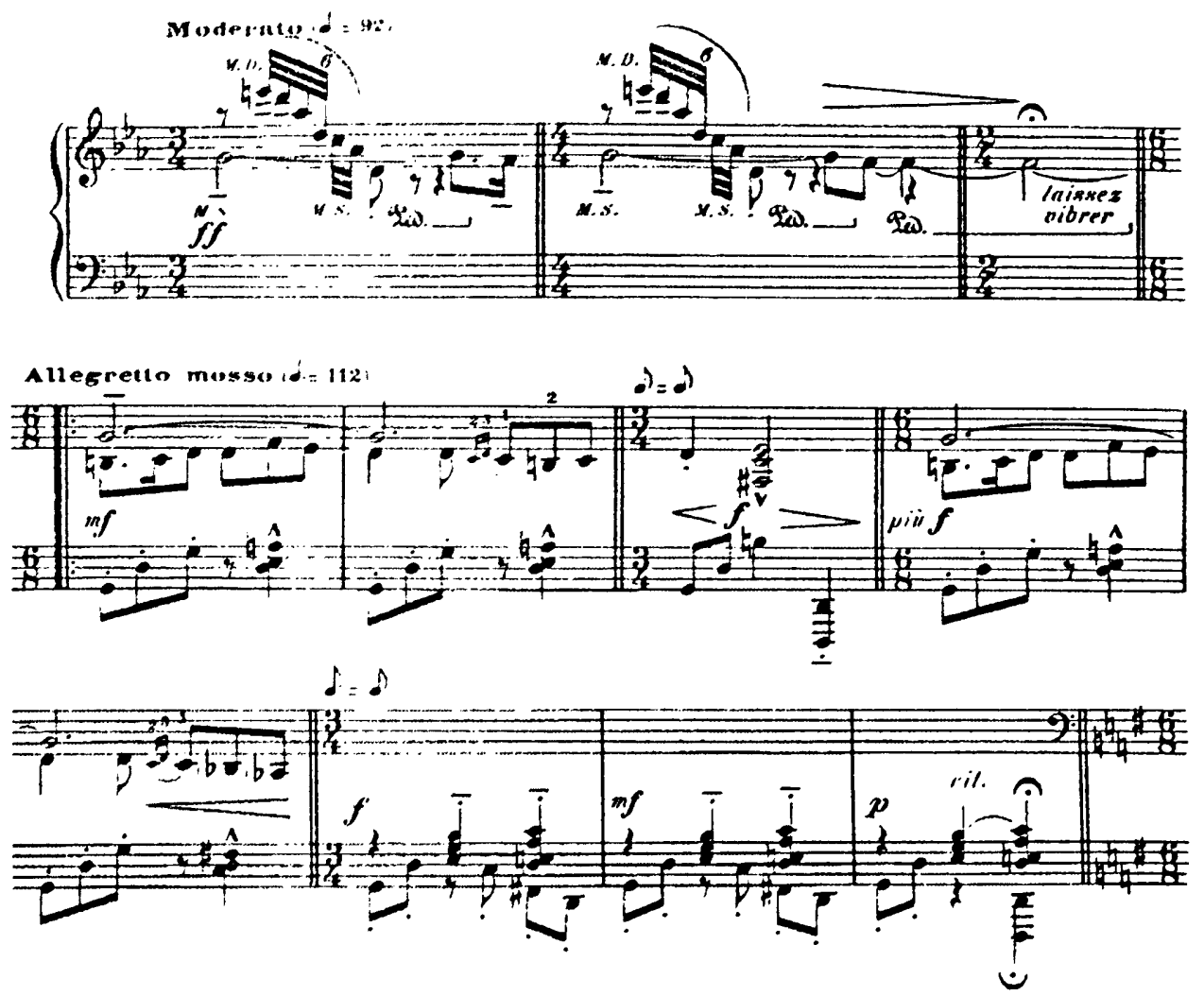

Figure 8 Villancico Castellano: piano introduction, mm. 1-11.

The fifth villancico is based on a popular theme from the region of Córdoba, which is located within Andalucia. This area was founded by the Romans due to its strategic importance as the highest navigable point of the Guadalquivir River. It was a major port city and we can hear the Moorish influence in the use of the appogituras and f\# leading tone. This villancico, composed in 1932 , also contains an emphasis in the poetry of the hard world that we live in where there is no charity. Jesus is in the form of the little boy, in white linen, asking to come in, but the world is closing its door to him. 

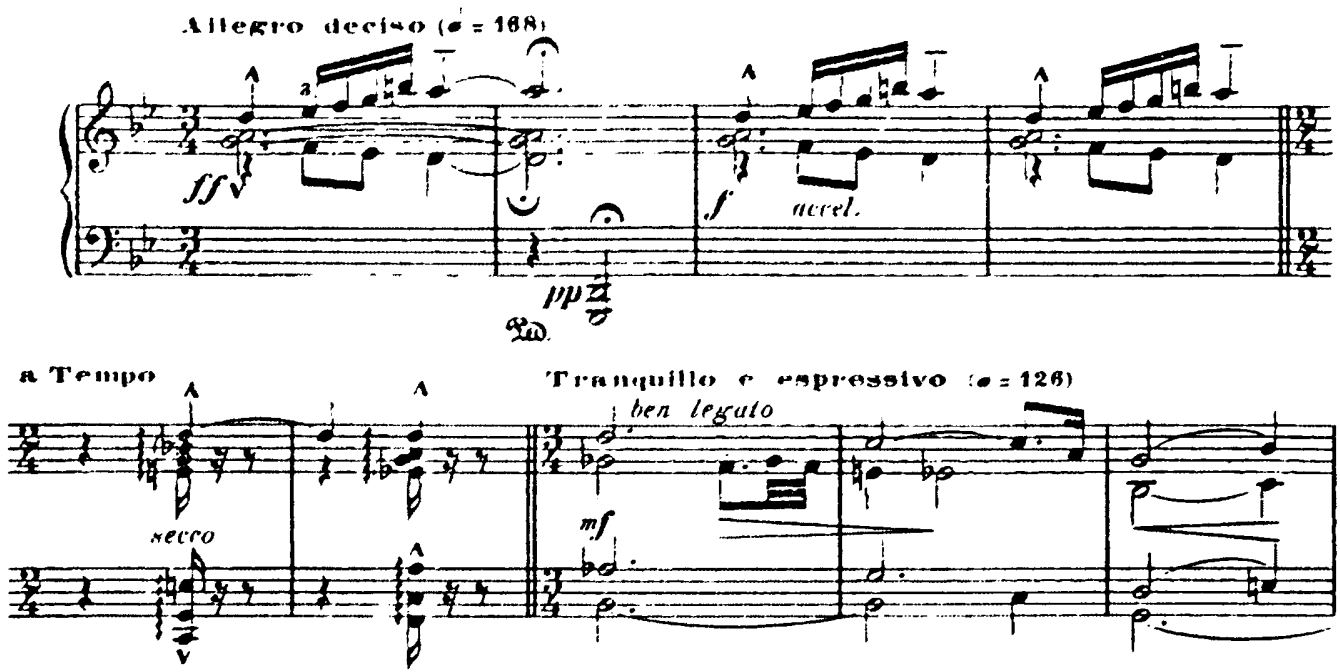

Figure 9 Villancico de Cordoba: piano introduction, mm.1-9.

The sixth villancico composed in 1932 to a popular theme is from the ancient kingdom of Murciano on the southeastern side of Spain between Andalusia and Valencia. The Aguinaldos songs of Christmas such as this one contain simple melodies, triple time and major tonality. This villancico is akin to the Valencian-Catalan group in that they have the typical dance of the region: the fandango. The fandango is $3 / 4$ time with octosyllabic verses, meaning there are eight syllables to each phrase with the emphasis on the seventh syllable. In this song, it is noteworthy that what is translated as "to give birth" is in Spanish "ha de alumbrar" or to enlighten. 


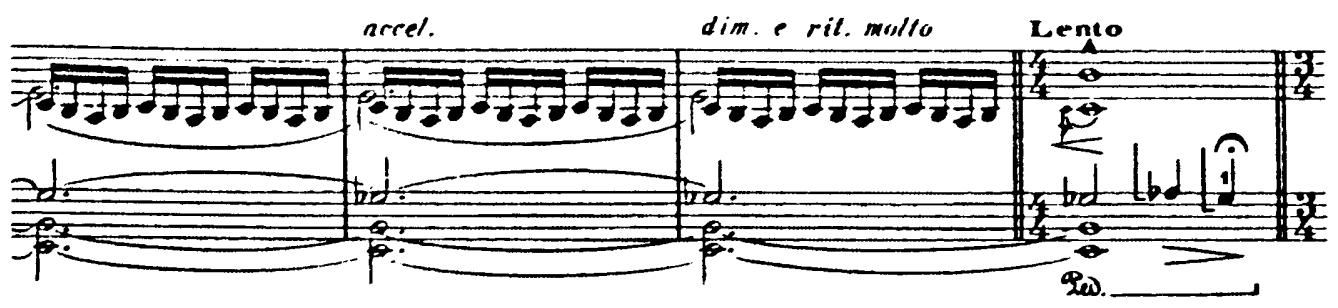

Figure 10 Villiancico Murciano: piano figure, $\mathrm{mm}$. 10-13.

The seventh villancico based on a popular theme, which was composed in 1933, Villancico aragonés, is perhaps the simplest, most typical example of a villancico. It contains four strophes and it is as if one were telling children the story of the birth of the Christ child. It has the references to the stable (el portal or the gateway), the mention of Bethlehem, the mula y el buey (mule and ox). It also speaks to his humble beginnings and who will dress him in velvet, the garment of kings.

The eighth villancico composed to a popular theme in 1933 is referred to as the Second Catalan Carol. The first carol was composed in 1923 and was included in his Canciones populares españolas. This is the only villancico that contains the Greek liturgical phrase, Kyrie Eleison. In catholic services this is what is recited at the beginning of mass and is known as the penitential rite. It is a petition for the Lord's mercy, his forgiveness. However, this is not a sad song, but a celebration of Christ's redemption. It is also in the language of Catalán, the language of his father and it was also the year of his affair with his daughter. Could Nin be asking for mercy?

The ninth villancico is from the southern most region of Spain, Seville in Andalucia. It is the only villancico not referred to as a villancico, but with a title, Jesús de Nazareth. Additionally, Jesús de Nazareth it is the only one with a completely original melody, one 
that is not from a popular folk theme. This villiancico was composed in 1933 and is the only one with a reference to a poet, Rodrigo de Reinosa, an early $16^{\text {th }}$ poet from the city of Reinosa in the Cantabria region. This poet was famous for his irreverent verses about the brothels of Seville. Reinosa did write one religious set called the Songbook of our Lady. There were four main factors in the development of Andalusian folk music 1) adoption of many elements of Byzantine chant by the primitive church in Spain; 2) Muslim invasion and occupation for centuries 3) Immigration by the gypsies, most of which settled in Andalusia 4) the cante Jondo or Jewish synagogue chant. The Cante Jondo is characterized by the use of microtones, sliding the voice from one note to another and melodies that move within a sixth. Also a single note repeated accompanied by appoggiaturas from above. The melodic embellishment is as a result of the lyrical expansiveness caused by the emotive force of the words. Although Andalusia is often thought of as a land of "perpetual gaity," suffering is the chief burden of most of the songs of the region, certainly those of the Arabic-Hebraic-Gypsy variety. Anna Bartos in her article entitled, "The Golden age revisited in $20^{\text {th }}$ century art songs" believes that this song has the precursor in a Sephardic lullaby sung by a mother who is anxiously awaiting her husband's return from the fields, all the while fearing that he has been unfaithful to her (DaSilva 2004, 57). This villancico is dedicated to the Christ Child and has the verso octosilábico or eight syllable lines with stress on the seventh, in a rima asonante rhyme of the penultimate vowels, common to the Golden Age of poetry (DaSilva 2004, 58).

Un niño nace de flores, Todo vestido de amores, Es de las flores la flor, Y el amore de los amores 

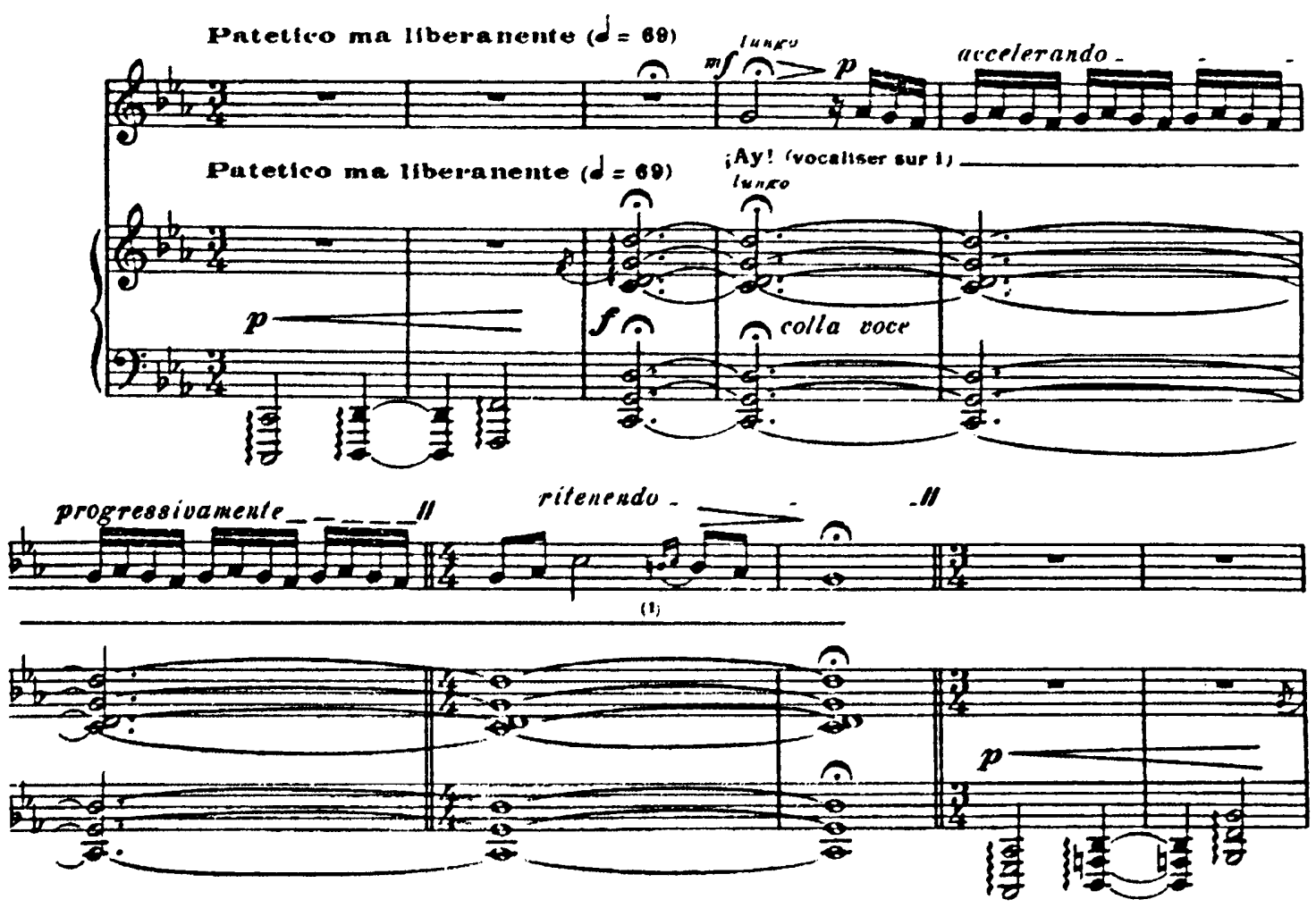

Figure 11 Jesús de Nazareth: “Ay!” Vocal motive: mm. 1-10.

The tenth and final villancico, Villancico Andaluz, was composed in 1932 and it is from a very popular theme, one that has remained to this day a favorite Spanish carol. It is a joyfully rhythmic celebration of the birth of our Savior. The piano introduction contains the celebration of the "bells" in the last three large chords contains the nativity story and the bells played by the angels (campanas de Belén que los angeles tocan) announcing His birth. 


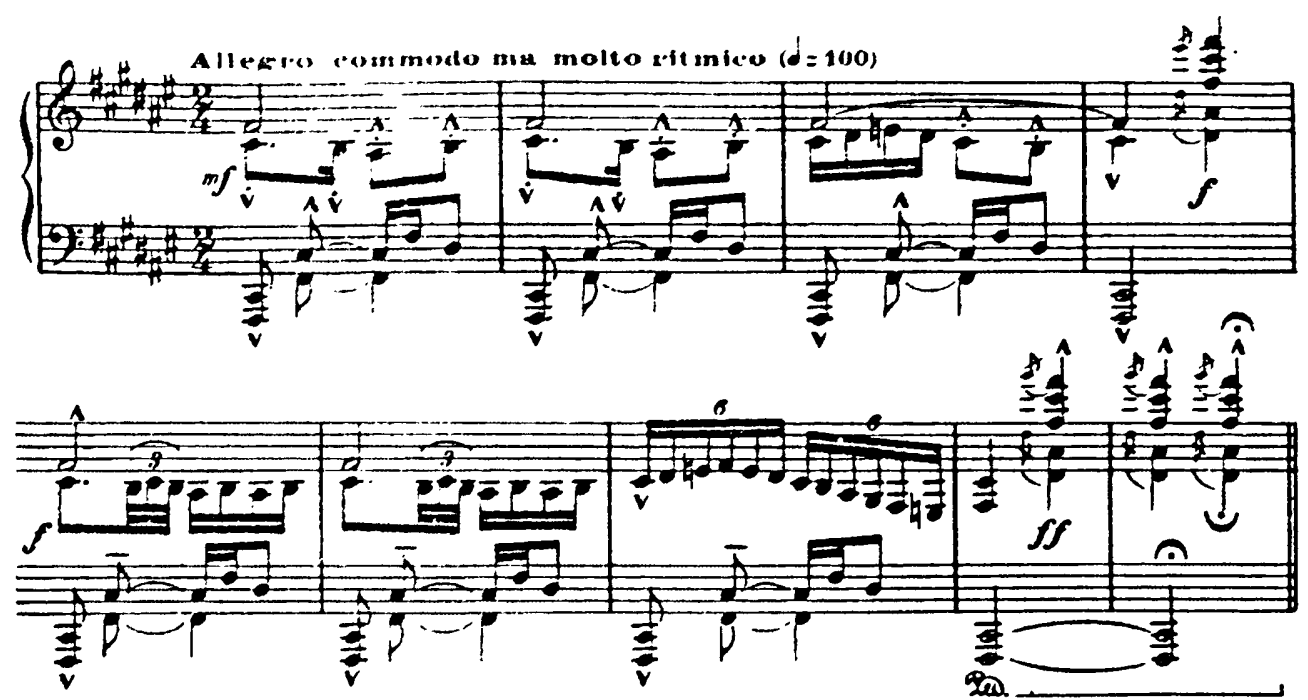

Figure 12 Villancico Andaluz: piano introduction, mm. 1-9. 
IV. Gabriel Fauré: Three Songs

"Fauré (1845-1924) is often categorized as a mere salon composer, and in the best sense of the word he was. The small musical forms, particularly songs, piano pieces and chamber music, music meant to be performed in a relatively small intimate space - make up the bulk of his compositions." (Gartside 1996, 19) Fauré's education during his formative years significantly influenced his compositional tendencies. Fauré was born on May 12, 1845, in the small town of Palmiers to a modest family. He was trained in the strict Niedermeyer School that focused on music composed before 1750. Niedermeyer became a teacher and father to the young Fauré, for Fauré became the "apple of his eye" (Nectoux 1991, 8). Already naturally a modest man, his education at the Niedermeyer School solidified his taste for restraint in composition and abhorrence of the use of dramatic grand gesture. Niedermeyer suddenly died in March of 1861, which devastated the boy. However, shortly after this time of distress, Fauré met Camille Saint-Saëns (1835-1921), who would become more than a teacher, but also a friend and mentor. It was under Saint-Saëns's tutelage that Fauré began to compose. However, Saint-Saëns not only influenced his compositional style, but also helped him in a more practical and financial sense, by introducing him to the wider musical world and members of the elite. It was Saint-Saëns who exposed Fauré to Victor Hugo, Schumann and Wagner. Additionally, it was his introduction to the Paris elite community that would gain him entrée into various musical soirées. There his songs could be performed by amateur singers, most often women. In fact, since it was very much in style for young women to study voice during that time, Fauré often served as accompanist to these amateur singers. 
While his compositions were being performed in the salon, the contemporary artistic community of France was also discussing them. During the first quarter of the twentieth century, the highest compliment to a composer would be that he be hailed as sincere, that he would be able to "maintain a singleness of voice amid such variables as poetic inspiration, genres, forms, and the passage of time" (Caballero 2001, 15). When one hears a song or piano work by Fauré, it is clear that it can be none other than his composition.

Paul Dukas, a noted French composer himself, expresses eloquently in an essay a few years after Fauré's death how linked Fauré's compositions were to his character as a person:

In every beautiful work, it is the man the work expresses that counts first and foremost.

In this, what more luminous example to follow?

Those who had the joy of sharing Fauré's intimacy know how faithfully his art reflected his being - to the extent that his music at times would seem to them the harmonious transfiguration of his own exquisite charm. Others did their utmost to rise above themselves or, if they collaborated with a poet, to surpass that collaborator. Fauré, with a unique grace, without constraint, gathers every external impression back into his inner harmony. Poems, landscapes, sensations that arise from the spur of the moment or the fleeting wave of memories - whatever sources his music springs from, it translates above all his own self according to the varied moods of the most admirable sensibility (Caballero 2001, 24).

In the world of the French chanson, Fauré is regarded as one of its greatest masters, having composed over 100 chansons, with the majority being grouped in three collections. His musical settings have several distinct characteristics. Most notable are his handling of harmony and tonality where there are temporary modulations, 
modulations to remote keys and the use of the plagal cadence due to his early training in church music. Melodically, he tends to think more horizontally instead of vertically, with the melody being a linear expression of the harmony. Rhythmically, Fauré favors line over pulse, creating a sense that the music is seamless, much like the French language itself. Fauré was enormously careful in his choices of text. However, "he always tended to choose poetry in which the evocative character of the words was greater than their sonorous quality. It was the general 'feel' of the poem that interested him, not the meaning of particular words" Gartside, 1996, 24). Fauré is not concerned with text painting, but with creating an atmosphere, foreshadowing Debussy and Impressionism.

Dans les ruines d'une abbaye, op.2, no.1was composed in 1865 and is based on the poetry of Victor Hugo (1802-1885). This through-composed composition can be found in the Fauré's first collection of 20 songs. In that same year, 1865, Victor Hugo, $19^{\text {th }}$ Century poet, writer, theoretician and leader of the Romantic movement, published a set of poems entitled, Les chansons des rues et des bois, or The songs of the streets and woods. In Book One: Youth (Livre Premier: Jeunesse), Section VI, The eternal little romance (L'Eternel petit romance), one finds playful number 15, "In the ruins of an abbey." The poems compare the beginning and ending of a man's life. Here the text speaks of love and it is not until the very end that we realize that it is speaking not of two people, but of two birds. Fauré uses a relentless quarter note, eighth note, quarter note, eighth note $6 / 8$ rhythmic pattern in the voice part which matches the rhythm of Hugo's lengthy poem, but is not particularly musically interesting. It is important to sing with a seamless legato line, being mindful of the eighth notes in order to not shorten them. This 
rhythmic pattern coupled with the four-measure phrases in which the vocal line rises and falls seems to symbolize the playfulness and joy of the birds love.

The next two selections, Les Berceaux, op. 23, no. 1 (composed in 1879) and $\mathrm{Au}$ bord de l'eau, op. 8, no. 1 (composed in 1875) contain poetry by the first Nobel Prize Winner in Literature, Armand Sully Prudhomme (1839-1907). Prudhomme's poetry seems to embody Fauré's personal esthetic of restraint, sensibility and profound melancholy. In fact, Fauré was attracted to many of the poets like Prudhomme, who were of the Parnassianism movement, who espoused the ideal coined by Théophile Gautier of "art for art's sake." Prudhomme, Gautier and some 90 other poets in the movement strove for purity of form and art over other personal or social concerns. Additionally, both chansons express an affinity for the sea.

Les Berceaux is one of Fauré's most popular songs for the text is "immediately appealing, one with which many individuals can readily identify" (Gartside 1996, 104). Marie Claire Beltrando calls this "one of his finest and most somber songs," a "lullaby of death," a forshadowing of the Requiem (Nectoux 1991, 76). What is most ingenious about this composition in $\mathrm{ABA}$ form, is his use of the accompaniment to establish the rocking motion of ships, which is being compared to the rocking of the cradles. It is written in $12 / 8$ time and the piano starts simply, repeating the same tonality for the first two measure. The left hand starts with a series of triplets, but the last eighth note of the first triplet is tied to the first eighth note of the second triplet. The right hand has a continuous quarter note eighth not rhythm. This combination creates a feeling of rocking in the right hand and pitching in the left (Gartside 1996, 104). 


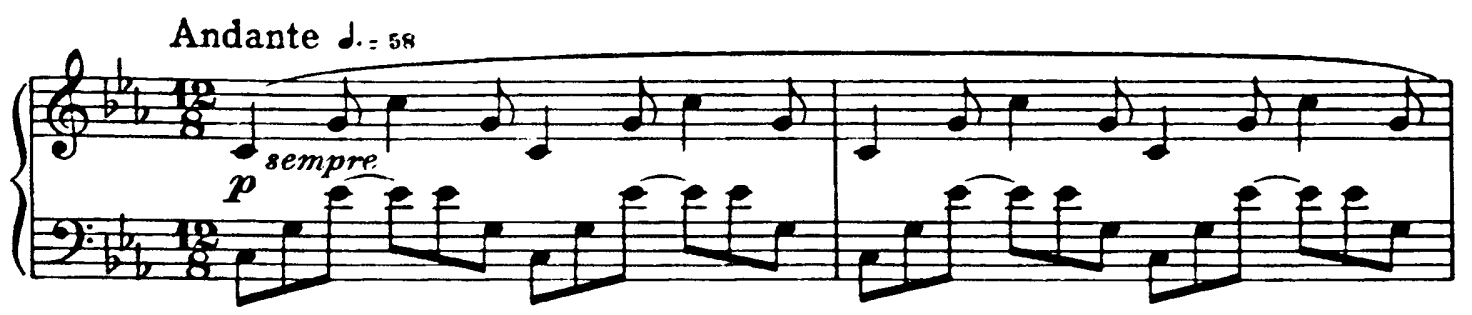

Figure 13 Les Berceaux: piano introduction with rocking rhythm, mm. 1-2.

Once the voice enters in the third measure, it seems as if the vocal line is growing right out of the piano part. The second section begins when the text speaks of the time of farewells and is marked with the vocal line written in even dotted quarter notes. Little by little there is a crescendo as the women begin to cry as the curious men are enticed to distant shores. He moves the main notes of the vocal line chromatically, building to a surprising altered III. Once the climax is reached, the vocal line floats back down an octave, symbolizing the men's yielding to the temptation of the life on the sea that they love. He modulates back to the original key and the A section returns, with alterations. Only the last line of the poem is repeated, Par l'âme des lointains berceaux (by the soul of the distant cradles). This is Fauré's song with the largest range, that of a $13^{\text {th }}$ and ending on a beautiful low note, the tonic, expressing the deep emotions of the Breton women who lost so many of their men to the call of the North Atlantic Sea.

Au bord de l'eau is a dreamy, somewhat melancholy chanson. The chanson begins in what became "one of his trademarks: a series of simple unadorned chords that the vocal line then spins out" (Gartside 1996, 75). Just as the poetry has the pattern of repeating the idea of the last line, the voice seems to continue the idea that the piano starts. Au bord de l'eau was composed during the time when he was in love with Madame Pauline Viardot. The songs during this period have the formula that Nectoux 
calls the "Viardot motif" of a rising sixth or octave followed by a stepwise descent down the scale, which is V, IV, III, II, I, VII, I (Nectoux 1991, 71). In the case of Au bord de l'eau, the descent is in equal eighth notes and requires a seamless legato. The ebb and flow of the melody seem to evoke the ebb and flow of the tide, giving the love a sense of timelessness. However, unlike Les Berceaux, the love is not lost but is depicted with the tonality changing from $\mathrm{c} \#$ minor to $\mathrm{C} \#$ Major, as never passing away (ne point passer). 
V. Sergie Rachmaninov: Three Songs

The greatly renowned Russian born pianist, conductor, and composer Sergei Rachmaniov (1873-1943) composed Oni otvechali, Op. 21, no. 4, Zdes Khorosho, Op 21, no. 7, and the Vocalise, Op. 34, no. 14. Rachmaninov occupies a very important place among Russian composers, being considered by music historians to be the last great representative of Russian late Romanticism (Slonimsky 2001, 2904). Rachmaninov composed some 82 songs from 1890-1916, a time considered to be the end of the Golden Age of Russian culture and the time of the Silver Age of refinement and drama.

When one thinks of Russian music, one thinks of the great symphonies of "the Mighty Handful"- Balakirev, Cui, Borodin, Musorgsky, and Rimsky-Korsakov or Tchaikovsky. When one thinks of Rachmaninov, one thinks of his great works for the piano with its broad rhapsodic sweeps of melodic line, fully expanded sonorities and fine, resonant harmonies. However, Russia has a "pesennaya kultura, a culture of song, where all of life, its joys and sorrows, holy days and work days were reflected upon in song. To sing (pet') expresses a vast range of feeling and emotion" (Challis 1989, 32). Song therefore is at the heart and soul of the Russian people and their music.

Rachmaninov entered the Moscow Conservatory to study and live with Professor Nikolai Zverev in 1885 . It was at the conservatory that he also became acquainted with Tchaikovsky, one of his great mentors. During the summer of 1890 Rachmaninov stayed at Ivanovka, the country estate of the Satin's his distant relatives. Ivanovka, deep in the Russian countryside and some 600 kilometers from Moscow became a place of retreat and respite for the composer. It was here that Rachmaninov would meet and marry his 
wife Natasha as well as compose more than thirty of his songs and over eighty-five percent of his total musical compositions. It was in Ivanovka that he was able to work poetically through loss and sorrow, "mellowed by the peaceful images of nature" (Challis $1989,40)$.

The vocal music of Rachmaninov derives its inspiration from liturgical poetry, Russian folk tradition and the secular poetry of Russia. What is interesting about these three genres is that they are all decidedly spiritual in nature. It would seem that to the Russian psyche, one cannot separate art apart from the spirit. When describing his own process, Rachmaninov states that "I compose slowly...for a long time, I walk surrounded by nature. My eyes encompass the reflection of light on leaves, fresh from the rain; I listen to the quiet whisper of leaves in the forest, or I observe the pale nuances of the sky on the horizon, and in my soul voices arise, all at once. Not a drop here, or a drop there, but all at once - a whole song arises" (Challis 1989, 45). For Rachmaninov, nature and particularly the Russian countryside was his source for vocal inspiration. After 1917, the year of his exile from his motherland, although he continued to perform and teach, he ceased to write songs.

Oni otvechali and Zdes Khorosho are from Rachmaninov's Songs of Opus 21, composed in 1902 at Ivanovka. The themes of these songs center around the idea that suffering and loneliness are inevitable parts of life, but emotional and spiritual understanding can be achieved through suffering. This is a decidedly Russian Orthodox concept with the emphasis of salvation and peace coming from the suffering on the cross of the savior of the world. 
Oni otvechali (They answered) is dedicated to Elena Kreutzer and is based on the poem Autre Guitare, (other Guitar) No. 23 from Les Rayons et les ombres (Rays and Shadows) published in 1838 by Victor Marie Hugo (1802-1885) and translated by Lev Alek Sandovich Mey (1822-1862). The great French Romantic poet Victor Hugo believed that by bringing poetry closer to man, making them walk universal paths above the struggles and parties of life, they would become civilized. In his collection of poems Les Rayons et le ombres Hugo juxtaposes the "rays" of passing through the joys of beauty, love and nature and the "shadows" of sadness, forgotten heroes, dead kings in order to form what we call life. Hugo entitles the poem Autre Guitare to poetically evoke guitar music. Rachmaninov seems to evoke the guitar in the accompaniment with its rolling chords. The poetry is a dialogue between men and women and utilizes the archaic Nominative plural masculine and feminine personal pronouns in order to retain the notion of "women's" answers to “men's" questions (Richter 2000, 39). In order to depict the poetry, Rachmaninov poses each question with urgency and a tempo marked allegro vivace; however, each answer is marked pianissimo, as if the women (and this is a decidedly feminine voice who answers) speak only in a whisper. 


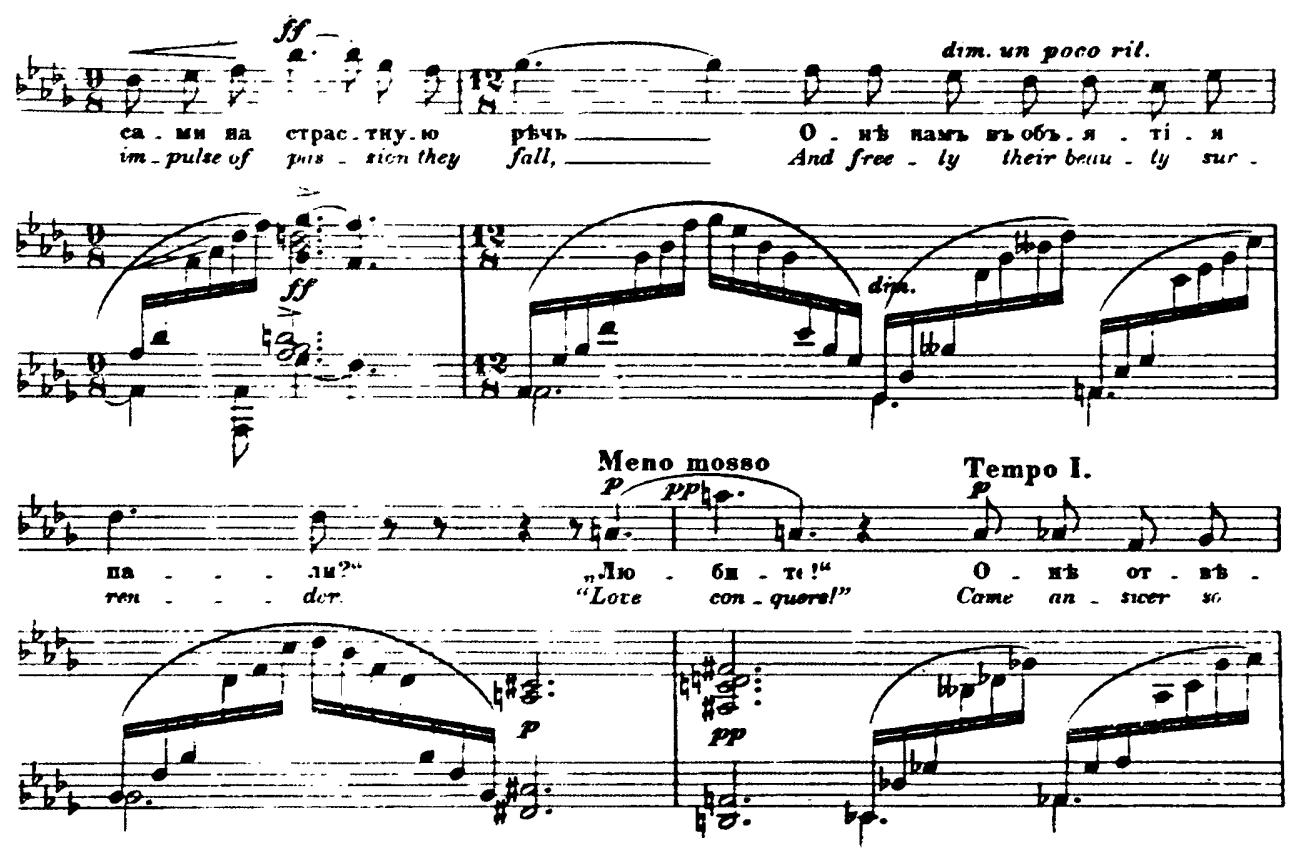

Figure 14 Oni otvechali: vocal part with the last "answer", mm. 18-24.

As each question is posed, the dynamics increase in volume, but the answer is always in a whisper, no matter how high the note the singer must sing, no matter how passionate the question, whether it concern how to succeed in life, happiness or love. All this would indicate that as we struggle with life's questions we must just listen attentively for the simple answer, to keep going, to sleep, to love.

Zdes Khorosho, (Its nice here) Op. 21, No. 7 contains poetry from a lesserknown poet, Glafira Galina, under the pseudonym Countess Einerling (1870-1942). However, do not be deceived by its humble origins, this musical offering is but a moment of outstanding beauty. In Zdes Khorosho, "Rachmaninov uses the melodic development of Russian protyzahnye (slowly sung) folk songs in which images of nature portray the spiritual and emotional state of the singer (Challis 1989, 102). Rachmaninov uses the triplet piano figure to invoke a feeling of $12 / 8$ time while the 
voice must soar quietly in $4 / 4$. The first notes are a and c\#, but it is it major or minor? It is not until the second measure that we realize we are not in A major, but $\mathrm{f} \#$ minor. The dominant is also minor and does not contain an e\# in the chord. The wonder that is expressed in the singer's voice, with its high tessitura sung pianissimo, complicated by the compound rhythmic figure is a wonder that is unsettled, not completely restful. There is a sense of awe as the singer states that there are "no people, only silence, only God and I." When the vocal line reaches its zenith, it is with a pianissimo that speaks louder than any forte ever could. The voice culminates in f\# minor, but the piano lingers, prolonging the beautiful moment, finally resting in a peaceful A major chord. As Vasinia-Grossman, so beautifully states, the "melody reveals itself in its unexpected beauty, as if realizing in music all the wealth of feelings, thoughts, reminiscences, which rise in our souls from a glance at familiar scenes of nature" (Challis 1989, 102).

The third selected song, Rachmaninov's Vocalise, Op. 34, No. 14, composed in 1915 published in 1916 and dedicated to the renowned Russian Soprano, Antonina V. Nezhdanova. Throughout his Opus 34, Rachmaninov brings together elements of ancient Russian chants and the classical tradition of the $19^{\text {th }}$ century, in contrast to the increasing modernism of Russian arts during the early years of the $20^{\text {th }}$ century. The Vocalise is the last song of the cycle, the only one composed in 1915, as opposed to 1912 when the rest of the Opus were composed. Here "words give precedence to the world of pure sounds" (Challis 1989, 171). In this song, Rachmaninov's affinity for Russian chant is most clearly evident for the free melody has its basis in a brief initial motif that is sung in variations, much like that of a Baroque Aria. Without the use of 
words, the voice becomes an obbligato instrument with the thematic material alternating between the voice and the piano.

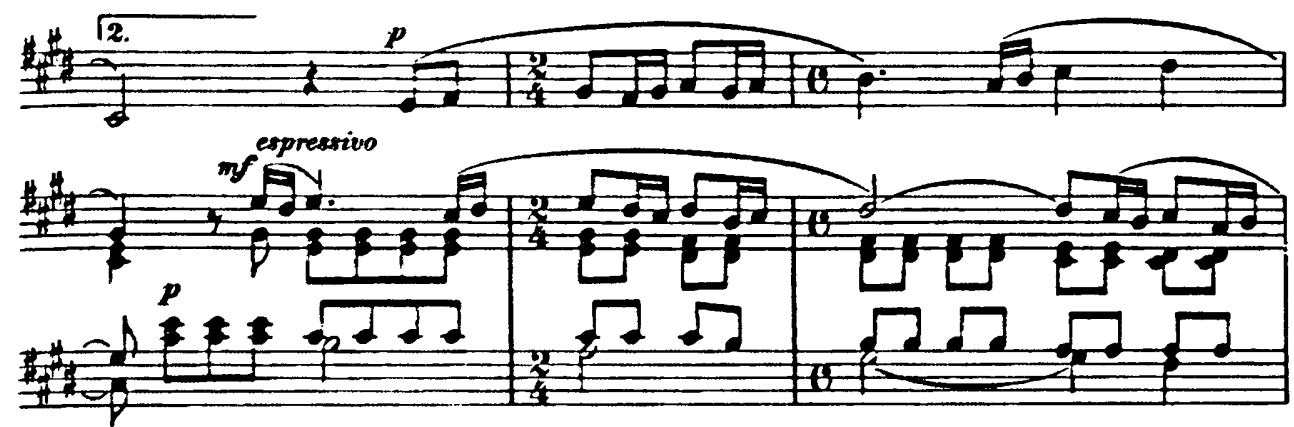

Figure 15 Vocalise: voice and piano counterpoint, mm. 33-35.

For Rachmaninov, the melody was music, "inasmuch as a perfect melody presupposes and calls to life a harmonic activity" (Challis 1989, 170). This hauntingly beautiful and melancholic melody seems to be infinite, penetrating the soul. 
VI. Libby Larsen: Cowboy Songs

Living composer Libby Larsen composed the set of three songs titled Cowboy songs in 1994. Although these three songs share a common theme of the Old West, they can be performed separately. Libby Larsen, born Elizabeth Brown Larsen in Wilmington, Delaware, is one of the most performed living composers, which is particularly noteworthy since she is one of only a handful of living composers that are not attached to a particular institution. Larsen not only is able to "make a living outside of Academia; she is one of America's most successful living composers, a major voice in American music" (Secrest 2007, 21). In her over 100 works that are comprised of choral works, song cycles, symphonic poems and opera, Larsen displays incredible versatility, for she is able to combine traditional and contemporary idiom to any given work. "Larsen approaches music as a total sensory experience flowing from speech. It employs all senses, not just auditory" (Burns 2002, 366).

During the course of her career Larsen has been a major force in promoting American Music. In 1973 she co-founded the Minnesota Composers Forum (now called the American Composers Forum), she has received numerous awards including a National Endowment for the Arts Composer Fellowship and in the same year that the Cowboy Songs was composed, Larsen won a Grammy Award for her Sonnets from the Portuguese. Larsen's music is immediately accessible with its emphasis on natural speech patterns, expressive piano accompaniments and easily relatable texts. Harmonically, Larsen is neither attached to the ideas of functional harmony, nor opposed to it. The driving force is simply the prose. In Larsen's own words, she states that her style is not recognizable in a "consistent use of harmonic language.... but in 
its rhythm." She believes that music "springs from the language of the people"... and she is "intensely interested in how music can be derived from the rhythms and pitches of spoken American English" Secrest 2007, 22). Larsen cites a varied list of influences from Gregorian Chant to Beethoven, to Blues, Techno and Rock and Roll. Gregorian Chant in particular laid a foundation for her concept of rhythm with its lack of bar lines. In fact, in an interview with Linda Moorhouse Larsen illustrates her affinity for what she calls "free flow" by first composing the music and then later creates a "grid of bar lines and meters" that she hopes will "make the music flow naturally"(Salzman, p.56).

The common subject of the American cowboy is what unites the three pieces titled Cowboy Songs. The text for the first song, "Bucking Bronco" is attributed to the female American outlaw, Belle Starr, alias Myra Maybelle Shirly, who was born in Missouri in 1848. Although immortalized in film and folk song, the Carthage Female Academy educated Belle was not a major criminal, but she was a horse thief. Her life was brought to an unfortunate end in 1889 , when she was ambushed and left to die.

In "Bucking Bronco," Belle speaks of her failed love affair with a cowboy. The song begins with the voice a capella in a rather free style, where there are twists and turns in the setting of the word "love," depicting the twists and turns of Belle's love with the cowboy. After the vocalist sings "rider" the second time, the accompaniment is energetic and rollicking, creating the feeling of being at a rodeo. 
The vocal line is very melodic and contains few leaps, which are used as a textpainting device as in the words "wild," "jump," and "high."

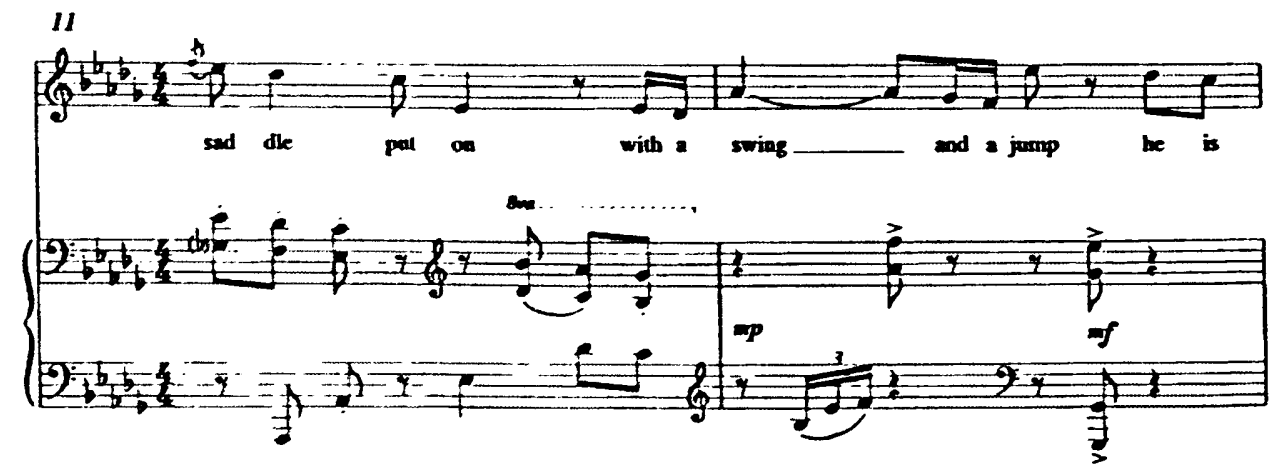

Figure 16 Bucking Bronco: example of text painting, mm. 11-12.

Since the language of the text is straightforward, so is the harmonic language, with standard chordal progressions in D Major. In addition, Larsen utilizes shifting meters of $6 / 4$ to $4 / 4$ and $3 / 4$ to accommodate the text. The structure is ABA, as it is for all three songs. When the A section returns, the voice is again a capella as the singer speaks clearly to the audience her warning about the perils of dating a cowboy. The piano part once again expresses the feel of the cowboy riding his bronco with the repeated rhythmic figure of four eighth notes played staccato followed by two rests. The song also makes use of double entendre with its references to "riding" being the way that he won her heart, which can make for a rather interesting interpretation of the text. 


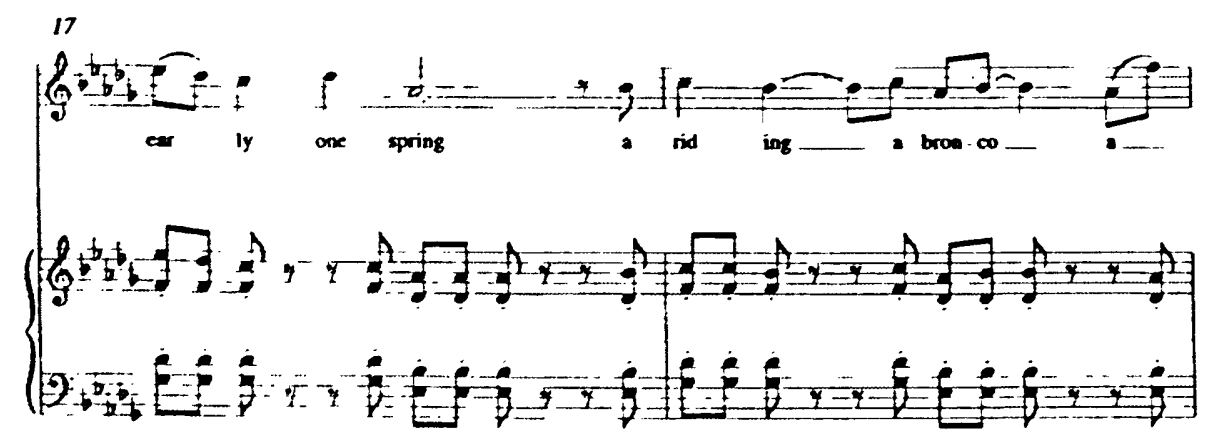

Figure 17 Bucking Bronco: piano rhythmic figure, 17-18.

The second song, "Lift me up to heaven slowly" is based on the poem published in 1978, "Sufi Sam Christian" by the American poet Robert Creeley (1926-2005). Here the cowboy is pensive, contemplating both his hard life and thoughts of heaven. The spacing of the accompaniment is wide, the metronome marking of slow, with the quarter note at 52 beats per second. The repeated accompaniment pattern seems to represent the movement of riding a horse. Again, Larsen utilizes text painting in the writing of "lift me." Also, there is repeated use in the vocal part of leading tones that must be sung slowly and deliberately, for the singer is "not even sure they want to go" to heaven. These slow chromatic movements help to illustrate a certain reluctance to go to the next level, whether it be taken literally as a spiritual heaven or a carnal, more earthly one. The speaker wants to take her time. 


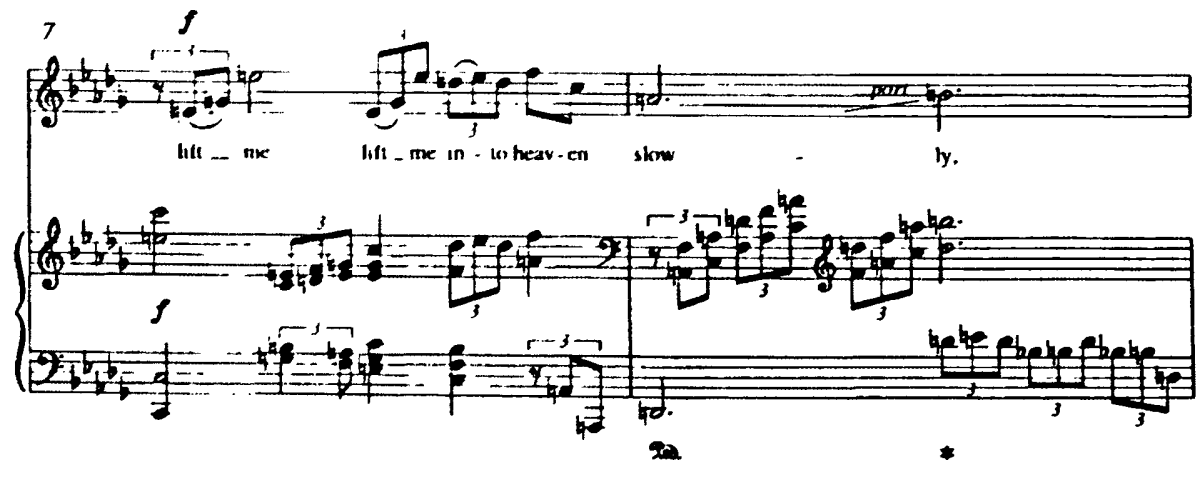

Figure 18 Lift Up To Heaven: vocal text paining, mm. 7-8.

"Billy the Kid," the last song in the grouping is from an anonymous setting of a rather notorious character. The piano accompaniment contains a musical quote from the familiar American folk song, Shortnin' bread. This quotation adds to the ironic character of the piece about an outlaw that became a legend.

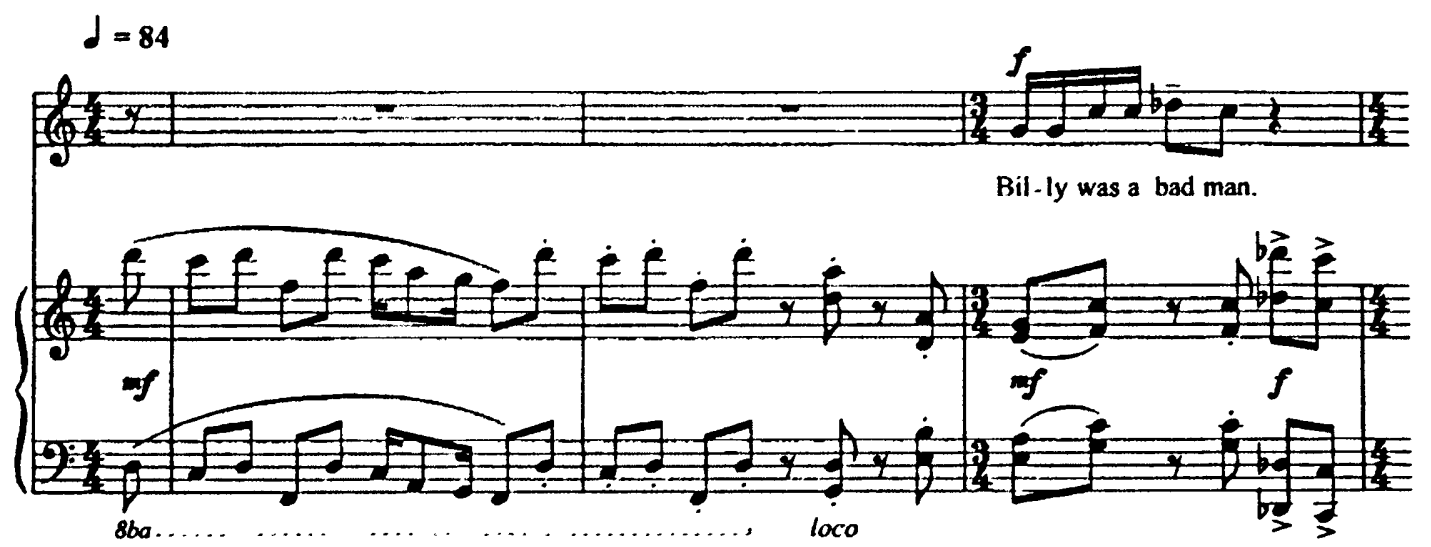

Figure 19 Billy the Kid: Shortnin' Bread quotation in piano accompaniment: mm. $1-3$

The vocal writing is agitated, containing both repeated notes and angular leaps. The text is filled with slang and colorful expressions like, "sass him," "feel his steel," 
"dead eye," "badder" and "ain't." The angular patterns of the vocal writing particularly illustrate the speakers "rage". In fact, to more fully emphasize the emotional intensity, the singer can choose to sing the ossia which contains a minor seventh interval leap from $e^{2}$ to $d^{b 3}$.

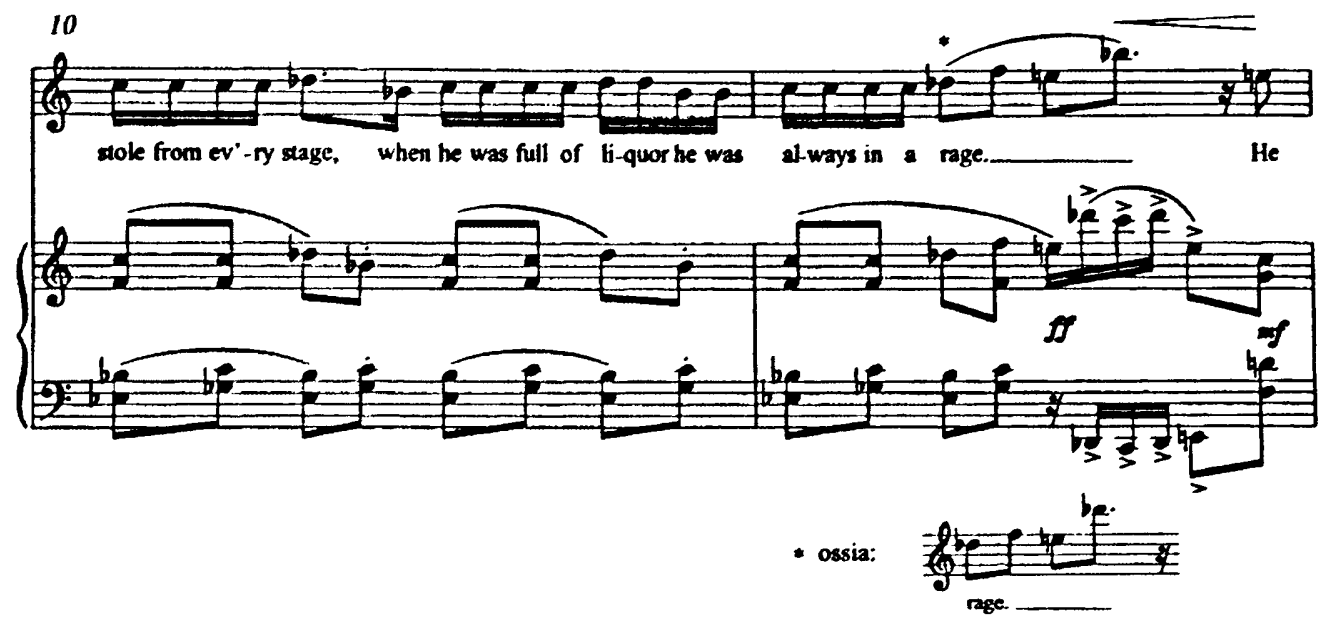

Figure 20 Billy the Kid: text painting of the word rage with ossia, mm. 10-11.

Once the vocal line has reached the sustained climax, the piano accompaniment returns with the ironic folk theme, adding comic impact to the last lines, "now he's dead and we ain't none the sadder." 

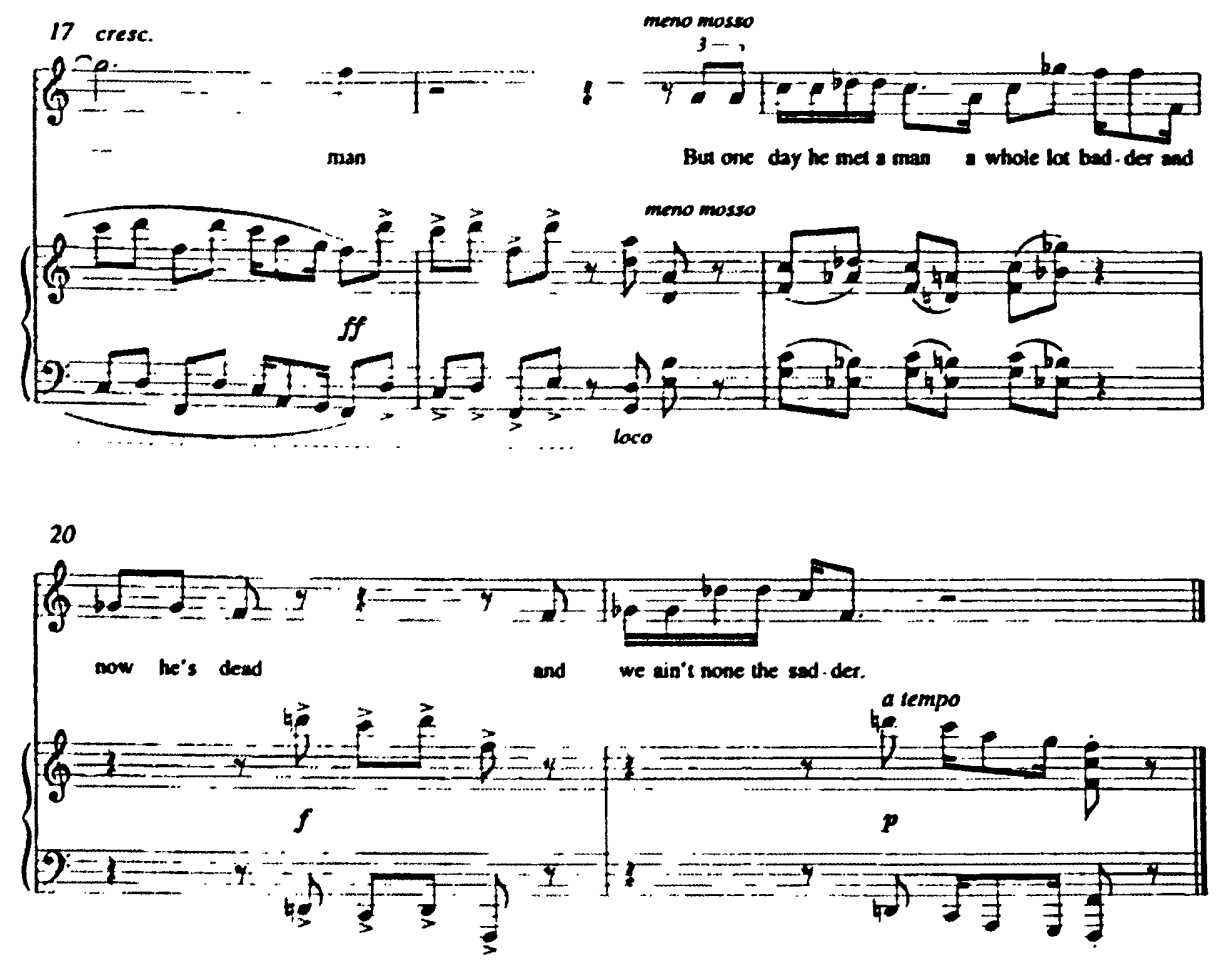

Figure 21 Billy the Kid": Return of Shortnin' Bread quotation, mm. 17-21.

\section{Conclusion}

The composers represented in this master's recital are taken from various styles, time periods, genres and languages. It was the author's intention to select repertoire of highest quality that was uniquely suited to the author's instrument and musical taste. Within the significant output of each composer, the author chose works whose texts resonated with her literary tastes. Lastly, in researching the composers it was discovered with the exception of Mozart, all of the composers wrote extensively on music, its meaning and its cultural significance. The desire on their parts was to serve art itself, a desire that this performer likewise shares. 


\section{LIST OF REFERENCES}

Abraham, Gerald, ed. 1990. New Oxford History of Music, Romanticism (1830-1890). Vol. 9. London: Oxford UP.

Albert, Hermann. 2007. W.A. Moazrt. New Haven: Yale UP.

Bernac, Pierre. 1970. The Interpretaton of French Song. New York: W.W. Norton and Company.

Brewerton, Erik. Rachmaninov's Songs, Music and Letters, 15:1, pp.32-36.

Burns, Kristine H., ed. 2002. Women and Music in America Since 1900. Vol. 2, L-Z. Westport, Connecticut: Greenwood.

Burns, Kristine Helen, ed. 2002 Women and Music in America Since 1900 An Encyclopedia. Phoenix: Oryx Pr.

Caballero, Carlo. 2001. Fauré and French Musical Aesthetics (Music in the Twentieth Century). New York: Cambridge UP.

Challis, Natalia, ed. 1989. Singer's Rachmaninoff. New York: Pelion.

Chase, Gilbert. 1959 The Music of Spain. New York, Dover Publications, Inc. .

Cockburn, Jacqueline. 1992. The Spanish Song Companion. London: Victor Golancz.

Cohen, Aaron I. 1987. International Encyclopedia of Women Composers. 2nd ed. New York: Books and Music

Cross, Eric. 2008. "Telemann Revived." Early Music 36.1, pp. 146-50.

D Silva, Zenia Sacks, ed. 2004. The Hispanic Conncetion: Spanish American Literature in the Arts of the World. New Haven, Praeger Publishers.

Elliott, Martha. 2006. Singing in Style a Guide to Vocal Performance Practices. New Haven and London: Yale University Press.

Gartside, Robert. 1996. Interpreting the Songs of Gabriel Fauré. Geneseo, N.Y: Leyerle Publications.

Johnson, Graham and Richard Stokes. 2000. A French Song Companion, Oxford: Oxford University Press. 
Kimball, Carol. 2005. Song, A Guide to Art Song Style and Literature. Milwaukee, WI: Hal Leonard Corporation.

Johnson, Graham and Richard Stokes. 2000. A French Song Companion. New York: Oxford University Press Inc.

Laird, Paul R. 1997. Towards a History of the Spanish Villancico. Warren, Michigan: Harmonie Park.

Landon, H.C. Robbins. 1990. The Mozart Compendium. New York: Schirmer Books.

Liukkonen, Petri, "René Sully-Prudhomme (1839-1907),"

Kirjasto,http://www.kirjasto.sci.fi/prudhomm.htm (January 8, 2005).

Locke, Ralph. "Laresen: The Cowboy Songs; Sonnets from the Portuguese; Try Me Good King." American Record Guide: Mar/Apr 68.2 (2005): 119-20.

Marco, Tomás, translated by Cola Franzen. 1993. Spanish Music in the Twentieth Century. Cambridge, Massachusetts: Harvard University Press.

Mather, Betty Bang. 1987. Dance Rhythms of the French Baroque a Handbook for Performance. Bloomington: Indiana UP.

McGee, Tomothy J., A. G. Rigg, and David N. Klausner, eds. 1996. Singing Early Music the Pronunciation of European languages in the Late Middle Ages and Renaissance. Bloomington: Indiana University Press.

Nectoux, Jean Michel. 1991. Gabriel Fauré, a Musical life. Cambridge [England]: Cambridge UP.

Neumann, Frederick. 1978. Ornamentation in Baroque and Post-Baroque Music: With Special Emphasis on J.S. Bach, Princeton, NJ: Princeton University Press.

Nin, Anaïs, and Anaïs Nin. 1983. The Early Diary of Anaïs Nin 1923-27 (Early Diary of Anaïs Nin). New York: Harcourt.

Pauly, Reinhard G. 1973. Music in the Classic Period. 2nd ed. Englewood Cliffs, N.J: Prentice-Hall.

Philippians. New American Bible. 1991. New York: American Bible Society.

Psalms. New American Bible. 1991. New York: American Bible Society.

"René François Armand Prudhomme,"

OldPoetry.com, http://oldpoetry.com/authors/Rene\%20Francois\%20Armand\%20Prudhom me (January 8, 2005). 
Richter, Laurence R. 2000. Rachmaninov's Complete Song Texts Russian Texts of the Complete Songs of Sergei Vasilyevich Rachmaninov. Geneseo, N.Y: Leyerle.

Rifkin, Joshua, Colin Timms, George J. Buelow, Kerala J. Snyder, Jack Westrup, and Martin Ruhnke. 1985. The New Grove North European Baroque Masters Schutz, Froberger, Buxtehude, Purcell, Telemann (The Composer Biography Series). Boston: W. W. Norton \& Company.

Sadie, Stanley, ed. 1980. New Grove Dictionary of Music and Musicians, 2nd ed., Vol. 8. London: Macmillan, Grove's Dictionaries of Music.

Sadie, Stanley. 2006. Mozart, the Early Years 1756-1781. New York: W.W. Norton and Company.

Salzman, Timothy Ed. 2003. A Composer's Insight: Thoughts, Analysis and Commentary on Contemporary Masterpieces for Wind Band, Vol. 2, Galesville, MD: Meredith Music Publications.

Sanchez, Marta. 1988. XVII Century Spanish Music Villancicos of Juan Francés de Iribarren. Pittsburgh, PA: Latin American Literary Review Press.

Secrest, Glenda D. 2007. "Songs from Letters and Cowboy Songs by Libby Larsen: Two Different Approaches to Western Mythology and Western Mythological Figures." Journal of Singing, September/October 64.1: 21-30.

Slonimsky, Nicolas, ed. 2001. Baker's Biographical Dictionary of Musicians, Vol. 5 Pisc-Stra. New York: Schirmer Books.

Slonimsky, Nicolas, ed. 2001. Baker's Biographical Dictionary of Musicians, Vol. 6 Stre-Zyli. New York: Schirmer Books.

St. Amour, Mary Paulina. 1969. A study of the Villancico. New York: AMS.

Stevens, Denis, ed. 1970. History of Song. Boston: W. W. Norton \& Company.

Walters, Richard. 1994. The Oratorio Anthology - Soprano The Vocal Library. New York: Hal Leonard Corporation.

Whybrow, Julia. 2009. Celle February. Web.

Wirsén, C. D. af, 2005. "The Nobel Prize in Literature 1901," Nobel Prize Website, http://nobelprize.org/literature/laureates/1901/press.html (January 8, 2005). 


\section{APPENDIX}

\section{SONG TEXTS AND TRANSLATIONS}

I. Georg Philipp Teleman: Lauter Wonne, lauter Freude (translated by Julia Whybrow)

Arie:

Lauter Wonne, lauter Freude, spielt in meiner regen Brust

Doch dem flammenreichen Herzen ist bist jetzt kein sündlichs Scherzen einer eitlen Gluht bewusst:

Gott allein ist seine Lust.

Rezitativ:

Dort labet sich ein Kind der Eitelkeit an aller Wollust dieser Zeit ein andrer ist auf Geld und Gut entflammt und seine Freude wächst zugleigh mit seinen Schätzen; der dritte wünschet kein Ergetzen, das nicht danebst aus hoher Ehre stammt; der vierte, wenn er sich an Feinden rächen kann, sieht dies für sein Vergnügen an; noch andern muß aus andern Dingen der Vorwurf ihrer Lust entspringen. Allein, wie schlecht ist diese Freude, wovon der Grund so leicht, ja oft so plötzlich weicht!

Wie schädlich ist die Weide, Die zwar, den Augen nach, beliebte Bluhmen trägt, und dennoch lauter Gift in allen Blättern hegt!

Ach, welcher sich in Christo nicht erfreut,

Dem bringt sein Freuen lauter Leid.

In Gott allein wird solche Lust gefunden, Die mit Bestand und Seligkeit verbunden.
Aria:

Sheer delight, sheer joy plays in my stirring chest Yet the richly enflamed heart is now unaware of sinful jokes a vain ardour is known God alone is his delight.

Recitative:

There feasts a child of vanity on all kinds of lust of this time another is on money and possessions kindled and his joy is growing simultaneously with his treasures; the third wishes no delight, would derive from high honor; the fourth, when he can on enemies take revenge, sees this for his pleasure; still others have made other things the reproach of their desire arise. Alone, how bad is this joy, on whose grounds so easily yes often so suddenly gives way! How harmful is the willow, That to the eye popular flowers bear, and has in all the leaves poison nurtured!

Ah, those who are in Christ not joyful To them brings their joy in suffering. In God alone such pleasure is found That with continuity and bliss united. 
Arie:

Ein stetes Zagen, ein ewigs Nagen, ein Trauren, das kein Ziel erhält, beschließet den Jubel der lachenden Welt.

Doch wer sich Gott zur Freude setzet, hat beides, was ihn hin ergetzet, und was ihm ewig wohl gefällt.
Aria:

A constant trembling

an eternal gnawing

a morn that receives no goal will conclude the jubilation of the laughing world. Yet to whom God their joy sets has both, making him delighted And for him forever full of pleasure.

II. Wolfgang Amadeus Mozart: Laudate Dominum from Vesperae solennes de confessore

Laudate Dominum omnes gentes

Laudate eum, omnes populi

Quoniam confirmata est

Super nos misericordia ejus,

Et veritas Domini manet in aeternum.Amen
Praise the Lord, all nations;

Praise Him, all people.

For He has bestowed

His mercy upon us, And the truth of the Lord endures forever. Amen.

III. Joaquin Nin y Castellanos: Diez Villancicos de Noël (translated by Piluca Codina)

\section{Villancico Asturiano}

No hay andar como andar a la una

$Y$ vereis el Niño en la cuna

Que nació en la noche oscura.

de Belén en un portal

Que no hay tal andar

No hay tal andar como buscar a Cristo

No hay tal andar como a Cristo buscar

Que no hay tal andar.

No hay tal andar como andar a las dos Y vereis al Hijo de Dios,

Que por nos salvar a nos sangre quiso derramar

Que no hay tal andar

No hay tal andar como buscar a Cristo No hay tal andar como a Cristo buscar Que no hay tal andar.

\section{Asturian Carol}

Nothing can compare with a walk at one When you see the Child in the cradle, Born in the dark night at Belen in a stable. Nothing can compare.

Nothing can compare with seeking

Christ,

With seeking Christ nothing can compare, Nothing can compare.

Nothing can compare with a walk at two, When you see the Son of God, Who to save us willingly shed his blood. Nothing can compare.

Nothing can compare with seeking Christ, With seeking Christ nothing can compare, nothing can compare. 
Villancico Gallego

Os angeliños d'a Gloria

Cantan cousas d'agradar

Os paxariños d'aterra

Cousas de moito pensar

Falade benbaixo Petade pouquiño

Praque non desperate $\mathrm{O}$ noso Ruliño

Vamas cantando e bailando

$\mathrm{Na}$ millor festa que hay

O nacemento d'o Neño

Qu'es tá n'os brazos d'a Naï

Falade benbaixo Petade pouquiño

Praque non desperate $\mathrm{O}$ noso Ruliño

Villancico Vasco

Ator, ator mutil etxera

Gastaña zimelak jatera

Gabon gaba ospatuteko

Aitaren ta amaren onduan;

Ikusico dok aita bareka

Amabe guztiz kontentuz

Villancico Castellano

San José era carpintero, carpintero ¡Ay!

Y la Virgen lavandera, la vandera ;Ay!

El Niño bajó del cielo

En una noche lunera

El Niño vino del aire

Camino del paraiso

\section{Villancico de Córdoba}

Madre en la puerta hay un niño

Más bello que flor de lirio

Cubierto de blanco lino

Madre el Niño tiene frío

Que venga a la lumbre y se calentará

¡Ay! Que en esta tierra ya no hay caridad ya no hay caridad

¡Ay! Ya no hay caridad
Galician Carol

The little Angels in the Glory

Are singing agreeable things

The little birds on the Earth

Things to think a lot about

Speak very low Make very little noise

For not to wake our little Child

We are singing and dancing

During the greatest feast to exist

The birth of the Child

Who is in her mother's arms

Speak very low make very little noise

For do not wake our little Child

Euskera Carol

Come, come home boy

To eat dry chestnuts

To celebrate Christmas Eve

Together with dad and mom

You'll see dad laughing

And mom very happy

Castilian Carol

Saint Joseph was a carpenter. Ah!

And the Virgin a washerwoman. Ah!

The child came down from heaven

on a moonlit night

The Child came from the air

On the road to Paradise.

Cordovan Carol

Mother at the door there is a boy

Prettier than the Iris

Dressed in white linen

Mother the child is cold

Let him come to the fire to warm up $\mathrm{Ah}$ ! In this world there is no charity, there is no charity Ah! There is no charity 
Villancico Murciano

Esta noche es Noche Buena

Buena noche de cantar

Que está la Virgen encinta

$\mathrm{Y}$ a las doce ha de a lumbrar

Gloria a la Virgen Santísima

Que esta noche ha de a lumbrar iAy!

Gloria al Padre Gloria al Hijo

Gloria a la Virgen María ¡Ay!

Villancico Aragonés

Atención a mis complicas

Porque voy con gran contento

A cantar las alabanzas

Del Sacgrado nacimiento

A caballo en un jumento

La Virgen a Belén marcha

Y San José va delante

Pisando nieve y escarcha

En un portalito oscuro

Llenito de telarañas

Entre la mula y el buey

Nació el redentor de almas.

Esta noche nació el Niño

Entre la paja y el heno

¿Quién pudiera, niño hermoso

Vestirte de terciopelo!

Segundo Villancico Catalán

Esta nit es nit de vetlla

Esta nit es nit de vetlla

Ha nascut d'una donzella

La miren i fa sol

Ha nascut d'una donzella

La Kyrie eleison

La Kyrie eleison

Ha nascut d'una donzella

Ha nascut d'una donzella
Murcian Carol

This night is Christmas eve

Good night for singing

The Virgin is expecting

And at midnight will give birth

Glory to the holy Virgin

Who will give birth tonight

Glory to the father, glory to the Son

Glory to the holy Virgin.

Aragonese Carol

Listen to my verses

Because with great happiness

I am going to sing the praises

Of the holy birth,

Riding on a donkey

The Virgin is going to Bethlehem

And Saint Joseph goes in front of her

Stepping on the snow and frost,

In a little dark stable

Plenty of cobwebs

Between ox and ass

The soul's redeemer was born,

That night the Child was born

Among the straw and the hay

Who could pretty Child

Dress you in velvet.

Second Catalan Carol

This night is the night of waking

This night is the night of waking

From a little maid has been born

They see her and the sun shines

From the little maid has been born

The Kyrie eleison. (Mercy of God)

The Kyrie eleison

From a little maid has been born

From a little maid has been born 
Un Infant como una estrella

La miren i fa sol

Un Infant como una estrella

La Kyrie elison

La Kyrie elison

Jesús de Nazareth

¡Ay! ¡Ay! Un niño nace de flores ¡Ay! Todo vestido de amores, de amores,

Es de las flores la flor

Y el amor del los amores.

Es Señor de los señores

Y la flor de los amores. ¡Ay!

Villancico Andaluz

Campana sobre campana

Y sobre campana una,

Asómate a esa ventana

Versa un Niño en la cuna.

Belén campanas de Belén

Que los ángeles tocan -

¿qué nuevas me traés?

Rocogido tu rebaño -

¿A dónde vas pastorcito?

Voy a llevar al Portal

Requesón manteca y vino.

Campana sobre campana

Y sobre campana dos;

Asómate a esa ventana

Porque está naciendo Dios.

Belén campanas de Belén

Que los ángeles tocan -

¿qué nuevas me traés?

Caminando, a medianoche -

¿a dónde vas mi buen pastor?

Le llevo al Niño, que nace

Como a Dios, mi corazón.
A child like a star

They see her and the sun shines

A child like a star

The Kyrie eleison

The Kyrie eleison

Jesus of Nazareth

Ah! Ah! A child is born of flowers.

$\mathrm{Ah}$ ! All clothed in love, in

love,

$\mathrm{He}$ is the flower of flowers

And the love of loves.

$\mathrm{He}$ is the Lord of Lords

And the flower of love. Ah!

Andalusian carol

Bell upon bell

And then one more bell, Look out the window

And you shall see a Child in the cradle.

Bethlehem, bells of Bethlehem

Which the angels ring -

What tidings do you bring me?

Once your flock is gathered,

Where dost thou go, little shepherd?

I am bringing to the stable

Butter, curds and wine.

Bell upon bell

And then two more bells,

Look out of the window,

For Christ is being born.

Bethlehem, bells of Bethlehem

Which the angels ring -

What tidings do you bring me?

Walking at midnight,

Where dost thou go, my good shepherd?

I am bringing to the Child, who is being born as God, my heart. 
IV. Gabriel Fauré: Three Songs (Translated by Peter Low)

Dans les ruines d'une abbaye

Seuls, tous deux, ravis, chantants,

Comme on s'aime;

Comme on cueille le printemps

Que Dieu sème.

Quels rires étincelants

Dans ces ombres, jadis pleines de fronts blancs,

De coeurs sombres.

On est tout frais mariés,

On s'envoie

Les charmants cris variés

De la joie!

Frais écho mèlés Au vent qui frissonne.

Gaîté que le noir couvent

Assaisonne!

Seuls, tous deux, ravis, chantants,

Comme on s'aime;

Comme on cueille le printemps

Que Dieu sème.

Quels rires étincelants

Dans ces ombres, jadis pleines de fronts blancs,

De coeurs sombres.

On effeuille des jasmins

Sur la pierre.

Où l'abbesse joint les mains, En prière.

Les tombeaux, de croix marqués,

Font partie

De ces jeux, un peu piqués

Par l'ortie.

On se cherche, on se poursuit,
In the ruins of the abbey

Alone together, enraptured, singing, how they love each other!

How they harvest the springtime

that God sows!

What laughter sparkling

Amongst these shadows

Once full of pale foreheads

of somber hearts.

They are both newly wed, they exchange

the charming, varied cries

that spring from joy -

Fresh echoes mingle

with the quivering breeze,

a gaiety to which the dark abbey

adds zest.

Alone together, enraptured, singing, how they love each other! How they harvest the springtime that God sows!

What laughter sparkling Amongst these shadows Once full of pale foreheads of somber hearts.

They pluck petals of jasmine on the marble sculpture where the abbess joins her hands in prayer.

The tombs, marked by crosses, are a part of these games, and so are one or two stings from nettles.

They lay at hide-and-seek; 
On sent croître

Ton aube, amour, dans la nuit

Du vieux cloître.

On s'en va se becquetant,

On s'adôre,

On s'embrasse à chaque instant,

Puis encore,

Sous les piliers, les arceaux,

Et les marbres,

C'est l'histoire des oiseaux

Dans les arbres.

Les berceaux

Le long du Quai, les grands vaisseaux, Que la houle incline en silence, Ne prennent pas garde aux berceaux, Que la main des femmes balance.

Mais viendra le jour des adieux, Car il faut que les femmes pleurent, Et que les hommes curieux

Tentent les horizons qui leurrent!

Et ce jour-là les grands vaisseaux, Fuyant le port qui diminue,

Sentent leur masse retenue

Par l'âme des lointains berceaux.

Au bord de l'eau

S'asseoir tous deux au bord du flot qui passe,

Le voir passer,

Tous deux s'il glisse un nuage en

l'espace,

Le voir glisser,

À l'horizon s'il fume un toit de chaume Le voir fumer,

Aux alentours si quelque fleur embaume S'en embaumer
They feel the coming dawn, Love, growing in the night of the old cloister.

They go on each other kissing They adore one another; They embrace at every moment Then again;

under the pillars, the arches and the statues, it's the story of the birds in the trees.

Cradles

Along the quay, the great ships, that ride the swell in silence, take no notice of the cradles. that the hands of the women rock.

But will come the day of farewells, when the women must weep, and curious men are tempted towards the horizons that lure them!

And that day the great ships, sailing away from the diminishing port, feel their bulk held back

by the spirits of the distant cradles.

At the edge of the water

To sit together beside the passing stream and watch it pass;

together if a cloud glides in the sky, to watch it glide;

On the horizon, if smokes a thatched roof

to watch it smoke, If nearby a flower smells sweet

To savior its sweetness 
Entendre au pied du saule où l'eau murmure, l'eau murmurer, Ne pas sentir tant que ce rêve dure Le temps durer.

Mais n'apportant de passion profonde Qu'à s'adorer,

Sans nul souci des querelles du monde

Les ignorer;

Et seuls tous deux devant tout ce qui lasse

Sans se lasser,

Sentir l'amour devant tout ce qui passe Ne point passer!
To hear at the foot of the willow where the water murmurs, the water murmurs;

to not feel so long as the dream endures, its duration;

but, having no profound passion except to adore one another, without concern for the world's quarrels, to ignore them;

and alone together, in the face of all wearying things, unwearyingly, to feel love (unlike all things that pass away) absolutely never pass way!

V. Sergie Rachmaninov: Three Songs (Translated by Faith Cormier)

Oni otvechali

Sprosili oni: „Kak v letuchikh chelnakh Nam beloju chajkoj skol'zit' na volnakh, Chtob nas storozha nedognali?" „Grebite!“ oni otvechali.

Sprosili oni: „Kak zabyt', navsegda, Chto v mire judol'nom jest' bednost', beda,

Chto jest' v njom groza i pechali?" „Zasnite!” oni otvechali.

Sprosili oni: „Kak krasavic privlech' Bez chary: chtob sami na strastnuju rech'

Oni nam v ob"jatija pali?" „Ljubite!“ oni otvechali.
She Answered

"How then," asked he "By boat and tide Alguazils flee?"

"Row," she replied.

"How then," asked he, "To set aside Strife, misery?" "Sleep," she replied.

"How then," asked he, "Love's filter denied, Win fair beauty?"

"Love," she replied. 
Zdes' khorosho

Zdes' khorosho...

Vzgljani, vdali

Ognjom gorit reka;

Cvetnym kovrom luga legli,

Belejut oblaka.

Zdes' net ljudej...

Zdes' tishina...

Zdes' tol'ko Bog da ja.

Cvety, da staraja sosna,

Da ty, mechta moja!

VI. Libby Larsen: Cowboy Songs

My Love is a Rider

My love is a rider, my love is a rider

My true love is a rider

Wild broncos he breaks,

Though he promised to quit for my sake

It's one foot in the stirrup

And the saddle put on

With a swing and a jump he is mounted and gone

The first time I met him

It was early one spring

A riding a bronco

A high headed thing.

The next time I saw him 'twas late in the fall

A swinging the girls at Tomlinson's ball.

He gave me some presents

Among them a ring

The return that I gave him

Was a far better thing:

A young maiden's heart.

I'd have you all know,

That he won it by riding his bucking bronco.

Now all young maidens,

Where're you reside,

Beware of the cowboy
How peaceful

How peaceful it is here

Look! far away

the river blazes like fire

The meadows are carpets of color

The clouds are radiant white

There's no one here

Silence reigns

I am alone with the Lord, the flowers, the old pine tree

And you, my dream of delight! 
Who swings rawhide,

He'll court you and pet you

And leave you to go

In the spring up the trail

On his bucking bronco.

Lift Me Into Heaven Slowly

Lift me into heaven slowly,

Cause my back's sore

And my mind's thoughtful

Lift me, lift me into heaven slowly,

Lift me, lift me into heaven slowly,

'cause my back's sore

and my mind's thoughtful

and I'm not even sure I want to go.

I'm not even sure I want to go.

Lift me into heaven slowly, slowly.

Billy the Kid

Billy was a bad man,

Carried a big gun

He was always after good folks and he kept them on the run

He shot one ev'ry morning to make his morning meal;

Let a man sass him

He was sure to feel his steel.

He kept folks in hot water,

Stole from ev'ry stage,

When he was full of liquor

He was always in a rage.

He kept tings boilin' over,

He stayed out in the brush,

When he was full of deadeye,

Other folks'ld hush

Billy was a bad man

Billy was a bad man,

Billy was a bad man

But one day he met a man

A whole lot badder

And now he's dead

And we ain't none the sadder. 